婘 UNIVERSITY OF AMSTERDAM

\title{
THE RULES OF INTERNATIONAL ORGANIZATIONS AND THE LAW OF INTERNATIONAL RESPONSIBILITY
}

Christiane Ahlborn

Amsterdam Law School Legal Studies Research Paper No. 2011-04 Amsterdam Center for International Law No. 2011-03 


\title{
d. \\ Amsterdam Center for International Law \\ University of Amsterdam
}

\section{ACIL ReSEARCh PAPER No 2011-03 (SHARES SERIES)}

\section{The Rules of International Organizations and the Law of International Responsibility}

\author{
Christiane Ahlborn
}

Cite as: ACIL Research Paper No 2011-03 (SHARES Series), finalized 26 April 2011 (www.sharesproject.nl)

Amsterdam Center for International Law

Oudemanhuispoort 4-6

NL-1012 CN Amsterdam

website: www.jur.uva.nl/acil
SHARES Research Project Director: André Nollkaemper email: contact@sharesproject.nl website: www.sharesproject.nl 


\title{
THE RULES Of INTERNATIONAL ORgaNIZATIONS AND THE LAW OF INTERNATIONAL RESPONSIBILITY
}

\author{
Christiane Ahlborn ${ }^{*}$
}

This paper discusses the role of the so-called "rules of the organization" in the draft Articles on the Responsibility of International Organizations (DARIO), adopted by the International Law Commission (ILC) on first reading. While the rules of the organization occupy a central place in the DARIO, the ILC has decided not to take a "clear-cut view" on their legal nature as either international law or internal law of the organization. This paper argues that the ILC's indecision has left the DARIO with a fluctuating scope of application concerning various provisions such as the attribution of conduct, the breach of an international obligation, the obligation to make reparation, and countermeasures against an international organization. Since the rules of the organization are a term of art that was developed by the ILC in its work on the law of treaties and has rarely been addressed in legal scholarhip, Part 1 examines the legal nature of the different components of the rules of the organization: the constituent instruments, the acts, and the established practice of the organization. While the constituent instruments are contracts between States at the moment of the creation of an international organization, they operate as constitutions during the life of the organization, giving it the autonomy to create internal law in force between the subjects of its legal order, including its member States. Part 2 therefore suggests to reconceive the rules of the organization as "internal law" of the organization as long as the organization functions effectively so as to approriately reflect an international organization's constitutional autonomy for purposes of international responsibililty.

\section{CONTENTS}

INTRODUCTION 1

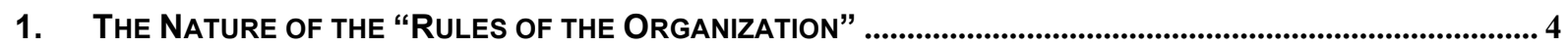

1.1 THE DUAL NATURE OF THE CONSTITUENT INSTRUMENTS

1.1.1 The Constituent Instrument as a Contract ............................................................................................................................

1.1.2 The Constituent Instrument as a Constitution................................................................................................................. 10

1.2 THE SINGLE NATURE OF THE SECONDARY LAW ………........................................................................13

1.2.1 Acts of the Organization ................................................................................................................................................... 14

1.2.2 Established Practice of the Organization ............................................................................................................................... 18

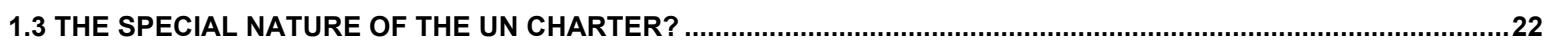

2. THE "RULES OF THE ORganization" IN THE LAW OF INTERNATIONAL RESPONSIBILITY ......................... 25

2.1 THE SCOPE OF APPLICATION OF THE GENERAL RULES

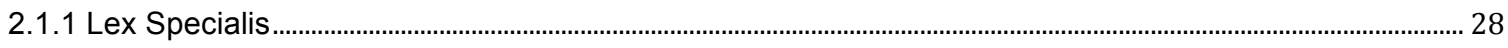

2.1.2 Applicability "Without Prejudice to the Charter of the United Nations" .................................................................... 32

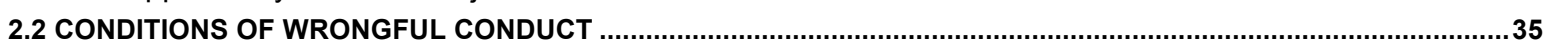

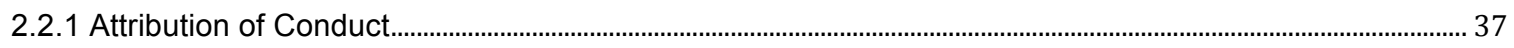

2.2.2 The Breach of a Rule of the Organization .................................................................................................................. 43

2.3 LEGAL CONSEQUENCES OF WRONGFUL CONDUCT ……............................................................................. 47

2.3.1 The Obligation to Provide Reparation ……................................................................................................................................... 48

2.3.2 Countermeasures by Member States............................................................................................................................................. 51

CONCLUSION: No INTERNATIONAL RESPONSIBILITY WITHOUT AUTONOMY ...........................................56

\footnotetext{
* Ph.D. Candidate, University of Amsterdam (c.s.ahlborn@uva.nl). The author would like to thank Jean d'Aspremont, Catherine Brölmann, Pieter Jan Kuijper, and André Nollkaemper for very valuable comments on earlier drafts of this paper, and the members of the project on Shared Responsibility for Responsibility in International Law (SHARES) for insightful discussions. The views expressed in this paper, including possible mistakes, are solely those of the author.
} 


\section{INTRODUCTION}

After the successful completion of its work on State responsibility in 2001, the UN International Law Commission (ILC) decided to take up the topic on of the responsibility of international organization as a suitable follow-up project. ${ }^{1}$ In elaborating the draft Articles on the Responsibility of International Organizations (DARIO), ${ }^{2}$ the ILC largely followed the model of its Articles on State Responsibility for Internationally Wrongful Acts (ASR). ${ }^{3}$ However, a number of key provisions in the set of DARIO, as adopted on first reading in 2009, include references to the "rules of the organization", which is one of the features distinguishing the DARIO from its well-known predecessor. Article 2 (b) of the DARIO provides that rules of the organization "means, in particular, the constituent instruments, decisions, resolutions and other acts of the organization adopted in accordance with those instruments, and established practice of the organization”. According to the ILC, these rules of the organization cannot be equated with the internal law of the State, for at least the constituent instruments pertain to international law and cannot be qualified as internal law of the organization. ${ }^{4}$ Instead the ILC does "not attempt to express a clear-cut view on the issue" of the legal nature of the rules of the organization as either internal law or international law, ${ }^{5}$ which has resulted in an ambiguous use of the term in various substantive provisions of the DARIO. ${ }^{6}$

Contrary to the ILC's above-stated position, a number of draft Articles almost mechanically use the term "rules of the organization" in lieu of "internal law" as applied in the corresponding provisions of the ASR. Mirroring Article 4 (2) of the ASR, the general rule on attribution of conduct in Article 5 (2) of the DARIO states that these "rules of the organization shall apply to the determination of the functions of its organs and agents". ${ }^{7}$ Similarly, Part III on the content of responsibility generally provides for the irrelevance of the rules of the organization with regard to the legal consequences of the wrongful conduct. Accordingly, Article 31 (1) stipulates that a responsible international organization may not rely on its rules to justify non-compliance with its obligation under this Part, replicating Article 27 of the ASR. Article 39 of the DARIO provides that the members of a responsible international organization are required to take, “in accordance with the rules of the organization”, all appropriate measures in order to provide the organization with the means for effectively fulfilling its

\footnotetext{
${ }^{1}$ ILC Report, Sixty-first Session, UN Doc. A/57/10 (2002), at 228-236.

${ }^{2}$ ILC Report, Sixty-first Session, UN Doc. A/64/10 (2009), at 13-178.

${ }^{3}$ ILC Yearbook 2001, vol. II (Part Two), at 26-143.

${ }^{4}$ First Report on Responsibility of International Organizations by the Special Rapporteur, Giorgio Gaja, UN Doc. A/CN.4/532 (2003), at 19 (para. 37).

${ }^{5}$ The ILC Commentary merely underlines that the principles expressed in the draft Articles apply "to the extent that an obligation arising from the rules of the organization has to be regarded as an obligation under international law.” ILC Report, Sixty-first Session, UN Doc. A/64/10 (2009), at 79 (para 6).

${ }^{6}$ See the critical comments regarding the "rules of the organization" received by governments, UN Doc. A/CN.4/636 (2011), at 15 (Portugal); international organizations, UN Doc. A/CN.4/637/Add.1 (2011), at 17 and 39; and the United Nations, UN Doc. A/CN.4/637/Add.1 (2011), at 4-6.
}

${ }^{7}$ Article 5 (General rule on attribution of conduct to an international organization): 1 . The conduct of an organ or agent of an international organization in the performance of functions of that organ or agent shall be considered as an act of that organization under international law whatever position the organ or agent holds in respect of the organization. 2. Rules of the organization shall apply to the determination of the functions of its organs and agents. 
obligation of reparation. ${ }^{8}$ The ILC Commentary explains that this obligation does not stem from international law and only has an expository function. ${ }^{9}$

While these draft Articles hence seem to attribute an internal character to the rules of the organization, other provisions of the DARIO conversely suggest that they are international in nature. Article 9 (2) extends the existence of a breach by an international organization to the violation of "an international obligation that may arise under the rules of the organization". ${ }^{10}$ Articles 21 and 51 of the DARIO further preclude an international organization and its member States or organizations from taking countermeasures vis-à-vis each other "unless [t]he countermeasures are not inconsistent with the rules of the organization". ${ }^{11}$ With regard to the provision of reparation, paragraph 2 of the abovementioned Article 31 specifies that the irrelevance of the rules of the organization in this regard is "without prejudice to the applicability of the rules of an international organization in respect of the responsibility of the organization towards its member States and organizations”. ${ }^{12}$ Finally, Article 63 on lex specialis states that the "rules of the organization applicable to the relations between the international organization and its members" may constitute "special rules of international law", allowing for derogation from the general rules of the DARIO. ${ }^{13}$

Considering the central role that the rules of the organization occupy in the DARIO, it is surprising that the ILC has not clearly characterized the legal nature of the rules of the organization. Although the reasons for the ILC's decision not to take a position on the nature of the rules of organization are, to a large extent, bound to remain subject to speculation, they are at least partly grounded in the well-known doctrinal controversy inherent in the organic tension at the heart of

\footnotetext{
${ }^{8}$ Article 39 (Ensuring the effective performance of the obligation of reparation): The members of a responsible international organization are required to take, in accordance with the rules of the organization, all appropriate measures in order to provide the organization with the means for effectively fulfilling its obligations under this chapter.

${ }^{9}$ ILC Report, Sixty-first Session, UN Doc. A/64/10 (2009), at 124 (para. 5).

${ }^{10}$ Article 9 (Existence of a breach of an international obligation): 1 . There is a breach of an international obligation by an international organization when an act of that international organization is not in conformity with what is required of it by that obligation, regardless of its origin and character. 2. Paragraph 1 includes the breach of an international obligation that may arise under the rules of the organization.

${ }^{11}$ Article 21 (Countermeasures): 1. Subject to paragraph 2, the wrongfulness of an act of an international organization not in conformity with an international obligation towards a State or another international organization is precluded if and to the extent that the act constitutes a countermeasure taken in accordance with the substantive and procedural conditions required by international law, including those set forth in Chapter II of Part IV for countermeasures taken against another international organization. 2. An international organization may not take countermeasures against a responsible member State or international organization under the conditions referred to in paragraph 1 unless: $(a)$ The countermeasures are not inconsistent with the rules of the organization; and $(b)$ No appropriate means are available for otherwise inducing compliance with the obligations of the responsible State or international organization concerning cessation of the breach and reparation. Article 51 (Countermeasures by members of an international organization): An injured State or international organization which is a member of a responsible international organization may not take countermeasures against that organization under the conditions set out in the present chapter unless: $(a)$ The countermeasures are not inconsistent with the rules of the organization; and $(b)$ No appropriate means are available for otherwise inducing compliance with the obligations of the responsible organization under Part Three.

${ }^{12}$ Article 31 (Irrelevance of the rules of the organization): 1. The responsible international organization may not rely on its rules as justification for failure to comply with its obligations under this Part. 2. Paragraph 1 is without prejudice to the applicability of the rules of an international organization in respect of the responsibility of the organization towards its member States and organizations.

${ }^{13}$ Article 63 (Lex specialis): These articles do not apply where and to the extent that the conditions for the existence of an internationally wrongful act or the content or implementation of the international responsibility of an international organization, or a State for an internationally wrongful act of an international organization, are governed by special rules of international law, including rules of the organization applicable to the relations between the international organization and its members.
} 
international organizations: On the one hand, it is widely accepted that international organizations are founded by their constituent instruments as closed entities with separate legal personality that interact with other subjects of international law horizontally. On the other hand, international organizations are said to form open political communities in which various actors, including sovereign States, operate according to rules enacted by the organs of the organization on the basis of the same constituent instruments in a vertical dimension. ${ }^{14}$

This paper argues that by deciding not to express a clear-cut view on the nature of the rules of the organization, the ILC tries to accommodate both of these dimensions into the current set of DARIO. The result is a precarious balancing act between the internal and international dimension of international organizations, which leaves the DARIO with a constantly fluctuating scope of application. Strangely enough, the ILC seems to be aware of some of the consequences of its indecisive position, ${ }^{15}$ which may also have more far-reaching systemic repercussions. By possibly subjecting the internal relationship between an international organization and its members to international law, the ILC's approach may collide with the foundational architecture of the law of international responsibility, as elaborated by the ILC from a positivist-dualist perspective over the past 60 years. While the open vertical image of a political community depicts international organizations more realistically, the law of State responsibility has mostly rested on the image of closed actors in their horizontal relations.

Against this background, this paper seeks to shed light on the nature of the rules of the organization in order to clarify the scope of application of the DARIO in view of the ILC's previous work on international responsibility. Since the "rules of the organization" have rarely been examined by legal scholarship, Part 1 will examine the legal nature of the individual components of the rules of organization - the constituent instruments, acts as well as established practice of the organization with particular emphasis on the origins of the term in the ILC's work on the law of treaties. While the constituent instruments of international organizations are contracts between States at the moment of the creation of an international organization, they operate as constitutions during the life of the organization, giving it the autonomy to create internal law in force between the subjects of its legal order, including its member States. In analyzing the role of the rules of the organization in the law of international responsibility, Part 2 will therefore argue that the rules of the organization are internal constitutional law for member States and the organization as long as the international organization

\footnotetext{
${ }^{14}$ See David J. Bederman, 'The Souls of International Organizations: Legal Personality and the Lighthouse at Cape Spartel', (1996) 36 Virginia Journal of International Law 275-377, at 371, stating that international organizations "see themselves as the embodiment of legal communities, with complex interplays of equal and subordinate relations with states, with other organizations, and within the organs of the entity itself.” For a discussion of images of international organizations as open and closed actors see Catherine Brölmann, The Institutional Veil in Public International Law: International Organisations and the Law of Treaties (Oxford: Hart Publishing 2007).

${ }^{15}$ As the ILC notes in its Commentary to Article 9 (2) of the DARIO: "the question of the legal nature of the rules of the organization is far from theoretical for the purposes of the present article, since it affects the applicability of the principles of international law with regard to responsibility for breaches of certain obligations arising from rules of the organization”. ILC Report, Sixty-first Session, UN Doc. A/64/10 (2009), at 79 (para 6).
} 
functions effectively. ${ }^{16}$ Accordingly, it is suggested that certain provisions of the DARIO be revisited so as to reflect more appropriately the constitutional autonomy necessary for an international organization to act as a subject of international law for purposes of international responsibility.

\section{THE NATURE OF THE "RULES OF THE ORGANIZATION"}

The phrase "rules of the organization" is a term of art developed and refined by the International Law Commission in its work on the Law of Treaties and on Representation of States in their Relations with International Organizations, as reflected in the pertinent conventions. Article 5 of the 1969 Vienna Convention on the Law of Treaties (VCLT) quite centrally states that the application of the Convention to a treaty which is the constituent instrument of an international organization or adopted within an international organization is "without prejudice to any relevant rules of the organization". ${ }^{17}$ Although the ILC had initially placed Article 5 (then Article 4 of its draft Articles) at the end of its draft Articles on the Law of Treaties as Article 48, it decided "that the article in question should be transferred to its present place in the introduction and should be reformulated as a general reservation covering the draft articles as a whole" on beginning its re-examination of the draft Articles at its 17th session. ${ }^{18}$ Article 3 of the 1975 Vienna Convention on the Representation of States in their Relations with International Organizations subsequently included the same formulation as the 1969 Vienna Convention, ${ }^{19}$ but the 1975 Convention explicitly refers to the "rules of the organization" in numerous other provisions. ${ }^{20}$ Given the importance of the rules of the organization in the 1975 Vienna Convention, Article 1 (34) also provides for a first definition of the term, based on the ILC Commentary on the same topic. ${ }^{21}$ Accordingly, rules of the organization "means, in particular, the

\footnotetext{
${ }^{16}$ To simplify the discussion, the following discourse only refers to the common situation of "member States" and not member "international organizations". However, it is acknowledged that an international organization can also be a member of another international organization, albeit in rare cases, as reflected in the text of the DARIO.

${ }^{17}$ Article 5 of the VLCT (Treaties constituting international organizations and treaties adopted within an international organization): "The present Convention applies to any treaty which is the constituent instrument of an international organization and to any treaty adopted within an international organization without prejudice to any relevant rules of the organization.” The ILC had chosen a stronger formulation for the reservation in its draft Articles on the Law of Treaties, which was modified at the 1969 Vienna Conference ("shall be subject to any relevant rules of the organization"). Vienna Convention on the Law of Treaties (1969), 1155 UNTS 331 [hereinafter: the 1969 Vienna Convention].

${ }^{18}$ As the ILC explained in its Commentary to Article 4 of its draft Articles (the later Article 5 of the 1969 VCLT) the transfer of Article 48 to the introductory part of the draft Articles on the Law of Treaties would enable it to simplify the drafting of other Articles containing specific reservations. It also thought "that such a general reservation was desirable in case the possible impact of rules of international organizations in any particular context of the law of treaties should have been inadvertently overlooked.” ILC Yearbook 1966, vol. II, at 187-274, at 191 (para. 1). With regard to the origins of the term "rules of the organizations, the Special Rapporteur on the Law of Treaties between States and International Organizations observed: "The wording of this reservation, i.e. 'subject to any relevant rules of the organization', seems to have been accepted at the time by the International Law Commission without any real difficulties, for it was proposed by the Drafting Committee and was neither explained nor discussed.” First Report of the Special Rapporteur on the Question of Treaties concluded between States and International Organizations or between two or more International Organizations, Paul Reuter, UN Doc. A/CN.4/258 (1972), at 182 (para. 36).

${ }^{19}$ Vienna Convention on the Representation of States in their Relations with International Organizations of a Universal Character, UN Doc. A/CONF. 67/16 (14 March 1975) [hereinafter: 1975 Vienna Convention on the Representation of States]. The Convention never entered into force, it has been ratified by 34 of the required 35 States.

${ }^{20}$ The Convention includes various references to the "rules of the organization" in Articles 1 (34) (Use of terms), 3 (Relationship between the present Convention and the relevant rules of international organizations and conferences), 5 (Establishment of missions), 10 (Credentials of the head of mission), 11 (3) (Accreditation to organs of the Organization), 18 (Location of the mission), 42 (Sending of delegations), 44 (Credentials of delegates), 71 (Sending of observer delegations).

${ }^{21}$ ILC Yearbook 1971, vol. II (Part One), at 288 (para. 5).
} 
constituent instruments, relevant decisions and resolutions, and established practice of the Organization”. This definition was taken over verbatim by Article 2 (j) of the 1986 Vienna Convention on the Law of Treaties between States and International Organizations and between International Organizations, ${ }^{22}$ and eventually found its way into Article 2 (b) of the DARIO.

While the Vienna Conventions do not specify the nature of the rules of the organization, it was understood in the respective preparatory works of the ILC and diplomatic conferences that the references to the rules of the organization are meant to safeguard the autonomy of the different kinds of legal relationships existing within an international organization. On the one hand, the rules of the organization were considered as lex specialis in force between the members of international organizations to contract out of a given general regime. ${ }^{23}$ For instance, in the travaux préparatoires to Article 5 (then Article 4) of the 1969 Vienna Convention, several delegations emphasized the residual character of the general law of treaties, and even stated that Article 5 was "superfluous from the legal point of view because States were always free to depart by mutual agreement from the rules laid down in the convention." ${ }^{24}$ On the other hand, it could be argued that the Vienna Conventions also employ the term rules of the organization to denote the so-called "internal law of the organization", which is classically used in scholarship to acknowledge that international organizations have their own legal orders. ${ }^{25}$ In this sense, Article 6 of the 1986 Vienna Convention refers to "rules of the organization" when recognizing that international organizations have the capacity to conclude treaties autonomously from their member States. ${ }^{26}$ This autonomy - as manifested in its separate will or volonté distincte - is

\footnotetext{
${ }^{22}$ Vienna Convention on the Law of Treaties between International Organizations and States and between International Organizations, 25 ILM 543 (1986) [hereinafter: the 1986 Vienna Convention].

${ }^{23}$ As one commentator explains with regard to the 1969 Vienna Convention, "[i]l a paru opportun de consacrer, de manière générale, une certaine autonomie des règles de fonctionnement des organisations internationales et de l' "affectio societatis » propre aux membres d'une organisation internationale, en vue de laisser s'épanouir leur ordre juridique spécifique." Patrick Daillier, 'Article 5 - Convention de 1969', in Oliver Corten and Pierre Klein (eds.), Les Conventions de Vienne sur le Droit des Traités : Commentaire article par article, Vol. I (Bruxelles: Bruylant 2006), 137-157, at 142.

${ }^{24}$ As stated by Mr. Bindschedler on behalf of Switzerland (Official Records of the United Nations Conference on the Law of Treaties, First Session (Summary records of the plenary meetings and of the meetings of the Committee of the Whole), A/CONF.39/C.1/SR.9 (1968)), who supported an amendment submitted by Sweden to delete draft Article 4 from the Vienna Convention on the Law of Treaties (see the statement of Mr. Blix on behalf of Sweden, which submitted an amendment to delete draft Article 4 (Official Records of the United Nations Conference on the Law of Treaties, First Session (Summary records of the plenary meetings and of the meetings of the Committee of the Whole), A/CONF.39/C.1/SR.8 (1968)). Other delegates were of the opinion that the general rules of the 1969 Vienna Convention should not only be "ius dispositivum" but at least partly mandatory or "ius cogens" and could therefore not be derogated from (see, for instance, the statement of Mr. Lukashuk on behalf of the Ukrainian Soviet Socialist Republic (Official Records of the United Nations Conference on the Law of Treaties, First Session (Summary records of the plenary meetings and of the meetings of the Committee of the Whole), A/CONF.39/C.1/SR.28 (1968)). The risks of such a derogation were expressed by Mr. McDougal on behalf of the United States of America, who "feared, however, that article 4, as it stood, conferred upon States a comprehensive, automatic and unquestionable exemption from the fundamental principles of the convention, if they chose to create an international organization or conclude agreements within the structure of such an organization." (Official Records of the United Nations Conference on the Law of Treaties, First Session (Summary records of the plenary meetings and of the meetings of the Committee of the Whole), A/CONF.39/C.1/SR.8 (1968)). On this point, see also the discussion on "lex specialis" in section 2.1.1 of this paper.

${ }^{25}$ Paul Reuter speaks of a "reconnaissance [...] opérée par la Convention de Vienne de 1969 que ces relations (des Etats membres entre eux et avec l'organisation au sein de cette dernière) sont règlées par un système juridique individualisé pour chaque organisation.” Paul Reuter, 'Sécurité des engagements internationaux', in Le développement de l'ordre juridique international. Mélanges Ganshof van der Meersch (Paris: Economica 1995), at 360. The term "internal law of the organization" is further discussed in section 1.2 "The Single Nature of the Secondary Law" of this paper.

${ }^{26}$ Article 6 of the 1986 Vienna Convention (Capacity of international organizations to conclude treaties): The capacity of an international organization to conclude treaties is governed by the rules of that organization.
} 
therefore a necessary precondition for international organizations to exist as separate legal persons in international law. ${ }^{27}$

While the term "rules of the organization" clearly has an advantage in its broad and inclusive meaning, ${ }^{28}$ it may also give rise to substantial ambiguity if the lex specialis applicable between sovereign States is not distinguished from the internal law of international organizations, ${ }^{29}$ for instance, in the law of international responsibility as discussed in Part 2 of this paper. In order to avoid this ambiguity, it is suggested here to acknowledge the dual nature of the constituent instruments (1.1): while they operate contracts between States at the moment of the creation of an international organization, they serve as constitutions governing the internal legal order of the organization during its life span. Considering that the constituent instruments are the bases of all other secondary law of an international organization, this law will necessarily only have an internal nature as limited by its constituent instruments (1.2). The interplay between the constitutional and contractual elements of the rules of an international organization will lastly be examined by focussing more specifically on the example of the UN Charter, which is often considered to have a special nature (1.3).

\subsection{THE DUAL NATURE OF THE CONSTITUENT INSTRUMENTS}

Since the time of the League of Nations attempts have been made to characterize the legal nature of the constituent instruments of international organizations by distinguishing them from other bilateral and multilateral treaties. Using the terminology introduced by Heinrich Triepel, ${ }^{30}$ RapiasiardiMirabelli concluded in 1925 that the various administrative unions established over the past hundred years were not based on simple contracts or traité-contrat between States that reconcile diverging interests, but rather on a special kind of convention, namely a traité-loi that objectivizes the individual interests of States towards the achievement of common goals. ${ }^{31}$ This distinction marked a considerable

\footnotetext{
${ }^{27}$ On the relationship between autonomy as separate will and legal personality see Nigel White, The Law of International Organisations (Manchester: Manchester University Press 2005), at 30 ff.; Henry G. Schermers and Niels M. Blokker, International Institutional Law: Unity within Diversity (Boston: Martinus Nijhoff Publishers 2003), at 34-35 (para. 44). See also Deirdre Curtin and Ige Dekker, ‘A Layered’ International Organization’, Paul Graig and Gráinne de Búrca (eds.), The Evolution of EU Law (Oxford: OUP 1999), 83-136, at 96.

${ }^{28}$ The ILC Commentary to Article 2 (j) of the draft Articles on the Law of Treaties between States and International Organizations and between International Organizations observes: "However, a question which occupied the Commission for some considerable time was that of the terms referring to the organization's own law, or that body of law which is known as 'the internal law' of a State and which the Commission has called 'the rules' of an international organization. The Commission has, finally, left its definition unchanged. There would have been problems in referring to the 'internal law' of an organization, for while it has an internal aspect, this law also has in other respects an international aspect. The definition itself would have been incomplete without a reference to 'the constituent instruments...of the organization'.” ILC Yearbook 1982, vol. II (Part Two), at 21 (para. 25).

${ }^{29}$ As Dallier observes: “L’historique de l'article 5 de la Convention reflète l'hésitation des Etats quant au degré de pouvoir discrétionnaire à reconnaître aux organisations internationales face aux Etats qui leur ont donné naissance et qui, au fil du temps, constatent la " concurrence » croissante des organisations en tant que sujets du droit international. Comme le rappelle P. Reuter : 'même pour les dispositions introduites dans la Convention sur le droit des traités et ne portant que sur les traités entre Etats, mais en relation étroite avec une organisation internationale, on perçoit l'hésitation et l'ambigüité'.” Patrick Daillier, 'Article 5 - Convention de 1969', in Oliver Corten and Pierre Klein (eds.), Les Conventions de Vienne sur le Droit des Traités : Commentaire article par article, Vol. I (Bruxelles: Bruylant 2006), 137-157, at 151.

${ }^{30}$ See Heinrich Triepel, Völkerrecht und Landesrecht (Leipzig: C.L. Hirschfeld 1899), 70-73. See also Hersch Lauterpacht, Private Law Sources and Analogies of International Law (London: Longmans, Green and Co. 1927), 156ff.

${ }^{31}$ See Andrea Rapisardi-Mirabelli, 'Théorie Générale des Unions Internationales’, (1925) II Recueil des Cours 345, at 348352, and 365. For an analytical overview of administrative unions and their powers, see Paul S. Reinsch, 'International Administrative Law and National Sovereignty', in (1909) 3 AJIL 1-45. The distinction between traité-contrat and traité-loi is
} 
departure from the consent-based inter-subjective international law of the $19^{\text {th }}$ century, by introducing islands of public order into its essentially private law structure. ${ }^{32}$ Pinpointing the ensuing structural uncertainty, Max Huber - writing in 1919 - described the League of Nations Covenant as "neither contractual nor constitutional” in nature. ${ }^{33}$

Today it is widely recognized that the constituent instruments of international organizations do not only have a contractual but also a constitutional character. ${ }^{34}$ However, instead of discussing the duality of the constituent instruments that are contracts and constitutions at the same time, Huber's "neither-nor" position seems to have been replaced by an "either-or" approach in international legal scholarship. ${ }^{35}$ While general international lawyers have traditionally classified the constituent instruments of international organizations in terms of the law of treaties, albeit by recognizing their special characteristics, ${ }^{36}$ scholars have increasingly focused on their constitutional traits, in particular

also used by Shabtai Rosenne, 'Is the Constitution of an International Organization an International Treaty', (1966) 12 Communicazioni e Studi 21-89.

${ }^{32}$ See Nigel White, The Law of International Organisations (Manchester: Manchester University Press 2005), at 14.

${ }^{33}$ Cited in Alfred Zimmern, The League of Nations and the Rule of Law, 1918-1935 (New York: Russell and Russell, 1969), 290-1. (Cited in White, at 14). See also Arnold D. McNair, 'The Functions and Differing Legal Character of Treaties', (1930) 11 BYIL 100-118, stating at 117 that "the treaties establishing them [administrative unions or commissions] have the quality of creating more than mere contractual relationships upon the parties. The create something organic and permanent and they seem therefore to demand recognition as falling into a special category of treaty, though in fact they form a species of the law-making treaty.”

${ }^{34}$ See, for instance, C. Wilfred Jenks, 'Some Constitutional Problems of International Organizations', (1945) BYIL 11; Lazar Focsaneanu, 'Le droit interne de l'Organisation des Nations Unies', (1957) 3 Annuaire français de droit international 315349; Philippe Cahier, 'Le droit interne des organisations internationales', (1963) 67 Revue général du droit international public 563-602, at 577; Hugo Hahn, 'Constitutional Limitations in the Law of the European Organizations', (1963) I Recueil des Cours 189-306, at 197; Shabtai Rosenne, 'Is the Constitution of an International Organization an International Treaty', (1966) 12 Communicazioni e Studi 21-89; Elihu Lauterpacht, 'The Development of the Law of International Organization by the Decisions of International Tribunals', (1976-IV) 152 Recueil des Cours 377-478, at 414-416; Herbert Miehsler, 'Qualifikation und Anwendungsbereich des internen Rechts internationaler Organisationen', (1973) 12 Berichte der Deutschen Gesellschaft für Völkerrecht 47-83, at 64; Ricardo Monaco, 'Le caractère constitutionnel des actes institutifs d'organisations internationales', in Mélanges offerts à Charles Rousseau: La Communanté internationale (Paris: Editions A. Pedone, 1975), 153-172; Edward McWhinney, 'The UN Charter: Treaty or Constitution?' in Edward McWhinney, Conflict or Compromise: International Law and World Order in a Revolutionary Age (New York: Holmes \& Meier Publishers, Inc. 1981), 54-70; Ronald St.J. Macdonald, ‘The United Nations Charter: Constitution or Contract?’, in Ronald St. J. Macdonald and D.M. Johnston (eds.), The Structure and Process of International Law: Essays in Legal Philosophy, Doctrine and Theory (Boston: Martinus Nijhoff Publishers 1983), 889-912; Tetsuo Sato, Evolving Constitutions of International Organizations (The Hague/London/Boston: Kluwer, 1996); Nigel White, The Law of International Organisations (Manchester: Manchester University Press 2005), at 14ff.; James Crawford, 'Multilateral Rights and Obligations', (2006-II) 319 Recueil des Cours 325-482, at 371ff.

${ }^{35}$ As Brölmann succinctly observes, "[t]he constituent instrument is seen either as a treaty (with which the organisation is equated), or as a constitution underlying the independent existence of the organisation.” Catherine Brölmann, The Institutional Veil in Public International Law: International Organisations and the Law of Treaties (Oxford: Hart Publishing 2007), at 144.

${ }^{36}$ As the ICJ stated in its Certain Expenses Advisory Opinion: "On the previous occasions when the Court has had to interpret the Charter of the United Nations, it has followed the principles and rules applicable in general to the interpretation of treaties, since it has recognized that the Charter is a multilateral treaty, albeit a treaty having certain special characteristics." Certain Expenses of the United Nations, Advisory Opinion of 20 July 1962, [1962] ICJ Rep. 151, at 157 [emphasis added]. Although the ILC occasionally referred to the "constitutions of international organizations", most notably in its Commentary to the draft Articles on the Law of Treaties between States (ILC Yearbook 1966, vol. II, at 207 (para. 20)), it has generally classified the constituent instruments of international organizations as treaties, without prejudice to their special characteristics. For an overview of the work of the ILC on the law of treaties applicable to constituents instruments, see Shabtai Rosenne, 'Is the Constitution of an International Organization an International Treaty', (1966) 12 Communicazioni e Studi 21-89. As Lauterpacht explains: "One reason for this general disinclination to point too firmly to the distinction between treaties which are constitutions and those which are not doubtless lies in the fact that a single instrument may contain both "constitutional" and "contractual" provisions." Elihu Lauterpacht, "The Development of the Law of International Organization by the Decisions of International Tribunals', (1976) Recueil des Cours 377-478, at 414-416. 
in the context of international institutional law. ${ }^{37}$ More recently, a growing number of constitutionalists have invoked the constitutional qualities of international organizations in an attempt to bestow them with legitimacy and to hold them accountable for their actions. ${ }^{38}$

Considering the dual nature inherent in the constituent instruments, it is submitted that neither the contractual law of treaties nor international institutional law can satisfactorily address the phenomenon of international organizations on its own account: they will have to be employed in combination. From the perspective of the law of treaties, the constituent instruments are primarily contracts between sovereign States, creating substantive rights and obligations as in a horizontal and international dimension (1.1.1). In contrast, an institutional or constitutional law perspective will clarify the extent to which this contract can equally be seen as functioning as a constitution: It establishes a new legal person with its own internal legal order, which binds the organization and its members in their vertical relations (1.1.2). ${ }^{39}$

\subsubsection{The Constituent Instrument as a Contract}

Most international organizations are created by virtue of a treaty, which is inter alia one of their common and defining characteristics. Since a few international organizations are founded by other legal acts governed by international law, in particular resolutions, the term constituent "instruments" is generally more accurately used than the term "treaty”. ${ }^{40}$ However, an "element of agreement” can even be found in non-treaty-based constituent instruments. ${ }^{41}$

\footnotetext{
${ }^{37}$ Henry G. Schermers and Niels M. Blokker, International Institutional Law: Unity within Diversity (Boston: Martinus Nijhoff Publishers 2003), at 722ff (para. 1145ff.); C.F. Amerasinghe, Principles of the Institutional Law of International Organisations (Cambridge: CUP 2005), 15-20. For a constitutional view on the constituent instruments of international organizations by different international courts and tribunals see, for instance, the European Court of Justice in 294/83, Parti écologiste ‘Les Verts' v. European Parliament [1986] ECR 1339, at para. 23; Loizidou v. Turkey (application no. 15318/89), European Court of Human Rights, 23 Mar. 1995 (Preliminary Objections), at para. 75; and Interpretation of the Agreement of 25 March 1951 between the WHO and Egypt, Advisory Opinion of 20 Dec. 1980, [1980] ICJ Rep. 73, at 89-90 (para. 37).

${ }^{38}$ For a selection of constitutionalist literature, notwithstanding the considerable variety of views, see Erika de Wet, 'The International Constitutional Order', (2006) 55 International and Comparative Law Quarterly 51-76; Erika de Wet, 'The Emergence of International and Regional Value Systems as a Manifestation of the Emerging International Constitutional Order', (2006) 19 Leiden Journal of International Law 611-632; Christian Walter, 'International Law in a Process of Constitutionalization', in Janne Nijman and André Nollkaemper (eds.), New Perspectives on the Divide Between National and International Law (Oxford: OUP 2007), 191-215; Anne Peters, 'The Merits of Global Constitutionalism', (2009) 16 Indiana Journal of Global Legal Studies 397-411; Alec Stone, 'Constitutionalism, Legal Pluralism, and International Regimes’, (2009) 16 Indiana Journal of Global Legal Studies 621-645; Jan Klabbers et al., The Constitutionalization of International Law (Oxford: OUP 2009). On constitutionalism generally see Armin von Bogdandy, 'Constitutionalism in International Law: Comment on a Proposal from Germany’, (2006) 47 Harvard International Law Journal 223. For a critical analysis see Jan Klabbers, ‘Constitutionalism Lite’, (2004) 1 IOLR 31-58.

${ }^{39}$ Focsaneanu rightly observes: "En ce qui concerne l’Organisation des Nations Unies, le milieu juridique plus vaste est représenté par la communauté internationale et le droit externe par le droit des gens. La Charte de San Francisco reflète, dans sa double nature de traité et de constitution, le dédoublement des plans juridiques." Lazar Focsaneanu, 'Le droit interne de l'Organisation des Nations Unies’, (1957) 3 Annuaire français de droit international 315-349, at 326 [emphasis added].

${ }^{40}$ This formulation was also chosen by the ILC for its definition of "international organization" in Article 2 (a) of the DARIO, and reflects widely accepted practice. See ILC Report, Sixty-first Session, UN Doc. A/64/10 (2009), at 44-45 (para. 4-5), with examples. See generally also Jan Klabbers, An Introduction to International Institutional Law (Cambridge: CUP 2002), 11; and Philippe Sands and Pierre Klein, Bowett's Law of International Institutions (London: Sweet \& Maxwell 2009), 448. This paper will mostly refer to term "constituent instruments" in its plural form since the agreement an establishing an international organization may consist of more than one instrument.

${ }^{41}$ Rosenne notes that "this element of 'agreement' exists even in those cases in which the constitution is not in a normal treaty form." Shabtai Rosenne, 'Is the Constitution of an International Organization an International Treaty', (1966) 12 Communicazioni e Studi 21-89, at 32.
} 
As international agreements, the constituent instruments of international organizations are best described as contracts between sovereign States, for it is commonly accepted that the concept of 'treaty' in international law has developed against the background of the concept of 'contract' in domestic private law. ${ }^{42}$ In fact, over many years the conception of contract seemed to offer the most appropriate model to depict the bilateral treaty relationships between equally sovereign States that characterized international relations even in multilateral settings such as peace conferences and an increasing number of international organizations. ${ }^{43}$ Therefore, in its work on the law of treaties, the ILC did initially not distinguish the constituent instruments of international organizations from other kinds of international agreements. As the third Special Rapporteur Fitzmaurice stated, there is "no substantial difference between any of these classes of treaties as regards the legal requirements governing their validity, interpretation and effect, since they are all based on agreement, and derive their legal force from its existence." ${ }^{44}$ At the time the ILC thus employed a unitary concept of treaty and justified this approach by the foundational importance of principle of consent that gives rise to an obligation (ex consensu advenit vinculum). As a result of their consent, States are bound to carry out their obligations in good faith (pacta sunt servanda) in relation to the other contracting parties. However, since a treaty is res inter alios acta, it does not create rights and obligations for third parties without their consent (pacta tertiis rule).

All constituent instruments of international organizations are based on the mutual consent of States, they can hence be seen as having a contractual element. It is certainly not a coincidence that many constituent instruments refer to the original founding States as "contracting parties". ${ }^{45}$ As a result of negotiations, the written constituent instruments are concluded in treaty form by duly authorized State representatives. After going through a process of negotiation, adoption and authentication of the text, their ratification will eventually lead a State to assume binding obligations vis-à-vis the other parties at a horizontal level. As contracts, the constituent instruments of international organizations are governed by the principles of "unanimity, combined with notions of common or shared interests and reciprocity". ${ }^{46}$ Accordingly, any change in the terms of contract requires the consent of the contracting parties. An insurmountable disagreement or change in the circumstances may result in the termination of the agreement by mutual consent and the conclusion of a new contract with different parties. ${ }^{47}$ Contracts are therefore usually of a non-permanent nature. In

\footnotetext{
42 Shabtai Rosenne, 'Is the Constitution of an International Organization an International Treaty', (1966) 12 Communicazioni e Studi 21-89, at 29. See Hugo Grotius, De iure belli ac pacis (1625), II, cap. xii, (with the significant title "De contractibus"); Hersch Lauterpacht, Private Law Sources and Analogies of International Law (London: Longmans, Green and Co. 1927), 155ff.; and Reservations to the Convention on the Prevention and Punishment of the Crime of Genocide, Advisory Opinion of 28 May 1951, [1951] ICJ Reports 15, at 21.

${ }^{43}$ See James Crawford, 'Multilateral Rights and Obligations', (2006-II) 319 Recueil des Cours 325-482, at 349-362.

${ }^{44}$ Report by the Special Rapporteur on the Law of Treaties, Gerald G. Fitzmaurice, UN Doc. A/CN. 4/101 (1956), at 108.

45 See Shabtai Rosenne, 'Is the Constitution of an International Organization an International Treaty', (1966) 12 Communicazioni e Studi 21-89, at 51-52; Niels Blokker, 'International Organizations and Their Members. 'International Organizations Belong to All Members and to None’ - Variations on a Theme’, (2004) 1 IOLR 139-161, at 140-141.

${ }^{46}$ Heidrun Abromeit and Tanja Hitzel-Cassagnes, 'Constitutional Change and Contractual Revision: Principles and Procedures’, (1999) 5 European Law Journal 23-44, at 31.

${ }^{47}$ See ibid., at 34.
} 
this sense, the contracting parties to the constituent instruments are truly the "masters of the treaties". Without their initial consent, the international organization would not exist, and they also have the power to terminate it. ${ }^{48}$ An international organization is the result of the freedom of contract of States, which allows them to create new legal persons. It is therefore not only the international agreement per se that defines an international organization, but also the fact that it is created by States or other subjects of international law, more broadly speaking.

While the law of treaties can thus explain how an international organization comes into being, the insistence on the principle of consent with regard to international organizations has confronted international law with certain conceptual challenges. For after the moment of their creation and until the moment of their termination, international organizations are considered to function autonomously without the explicit consent of the contracting parties to their constituent instruments. ${ }^{49}$

\subsubsection{The Constituent Instrument as a Constitution}

Considering the limited explanatory force of the contractual paradigm, it is suggested that the existence of international organizations as autonomous actors can only be explained by acknowledging the dual nature of their constituent instruments, which are not only contracts but also constitutions. While the law of treaties sets the conditions for the initial contractual consent between sovereign States, it has to be complemented by public or institutional law considerations to explain how this contractual consent establishes a new legal person whose constitution guarantees the autonomous functioning from its constituent elements and lays the foundation of a new legal order, which is separate from international law. ${ }^{50}$

At the moment of the creation of an international organization the contractual element of the constituent instruments is accompanied by a constitutional momentum that results in the creation of a

\footnotetext{
${ }^{48}$ On the autonomy of international organizations and their termination see Jean d'Aspremont, 'The multifaceted concept of the autonomy of international organizations and international legal discourse', in Richard Collins and Nigel D. White (eds.), International Organizations and the Idea of Autonomy (London: Routlegde 2011) at 66 [on file with the author]. See also Niels Blokker, 'International Organizations and Their Members. 'International Organizations Belong to All Members and to None' - Variations on a Theme', (2004) 1 IOLR 139-161, at 140ff. The dissolution of an international organization is a rather rare scenario; see generally Ramses Wessel, 'Dissolution and Succession: The Transmigration of the Soul of International Organizations', in Jan Klabbers and Asa Wallendahl (eds.), Research Handbook on International Organizations (Cheltenham: Elgar Publishers 2011), at 342-362.

${ }^{49}$ This fact has inter alia resulted in the increasing recognition that international organizations are endowed with international legal personality even without an express stipulation in their constituent instruments. On the debate on the legal personality of international organizations see Jan Klabbers, An Introduction to International Institutional Law (Cambridge: CUP 2002), 52ff; Philippe Sands and Pierre Klein, Bowett's Law of International Institutions (London: Sweet \& Maxwell 2009), 474.

${ }^{50}$ As Zoller states, "the Vienna Convention, which has a bearing solely on states, cannot regulate the relations between the Organization and its members in the same manner that it regulates the relations among member states. Similar reasoning may actually be applied to the relations between a state and its citizens. Such relations are not regulated by the law of contracts even though the state originated in a social contract." Elisabeth Zoller, "The "Corporate Will” of the United Nations and the Rights of the Minority', (1987) 81 AJIL 610-634, at 625. Focsaneanu develops his constitutional argument on the basis on the legal theory of institutions, see Lazar Focsaneanu, 'Le droit interne de l'Organisation des Nations Unies', (1957) 3 Annuaire français de droit international 315-349, at 326ff, which is further discussed by Ricardo Monaco, 'Le caractère constitutionnel des actes institutifs d'organisations internationales', in Mélanges offerts à Charles Rousseau: La Communauté internationale (Paris: Editions A. Pédone, 1975), 153-172. For a more recent application of the theory of legal institutions to the European Union see Deirdre Curtin and Ige Dekker, 'A Layered' International Organization', Paul Graig and Gráinne de Búrca (eds.), The Evolution of EU Law (Oxford: OUP 1999), 83-136.
} 
new legal person. By concluding the constituent instruments of an international organization, States act as a pouvoir constituant that gives itself a constitution to govern its own legal order, and thereby establish the pouvoir constitué, the international organization. ${ }^{51}$ In order to implement the object and purpose of their contract, as specified in the functions of the international organization, the contracting States will confer some of their own sovereign powers or competences ${ }^{52}$ upon the international organization. ${ }^{53}$

Speaking in contractual terms, the principal establishes an agent, which is the international organization whose exercise of public power in relation to its member States is determined by its constitutional documents. ${ }^{54}$ By establishing a new legal person, States use their freedom of contract, to undertake collectively what none of them could achieve individually. ${ }^{55}$ Accordingly, it takes more than one State or other subject of international law to establish an international organization, which is besides its treaty foundation - its second defining characteristic. It is this collective conferral of powers to a new legal person, and the correlative creation of an autonomous legal order, ${ }^{56}$ that decisively distinguishes the constituent instruments of international organizations from other international contracts, including multilateral conventions. By conferring competences to the international organization, the individual wills of the contracting parties merge into the corporate will of the international organization, which has autonomy or distinct will from its constituent parts as guaranteed by its constitution - the third and most important characteristic of international organizations. ${ }^{57}$

By virtue of this collective conferral of powers, the contracting parties themselves become member States of the organization, or - as the word "member" suggests - they become parts of a

\footnotetext{
${ }^{51}$ See generally Heidrun Abromeit and Tanja Hitzel-Cassagnes, 'Constitutional Change and Contractual Revision: Principles and Procedures', (1999) 5 EJIL 23-44, in particular at 30; James Crawford, 'Multilateral Rights and Obligations', (2006-II) 319 Recueil des Cours 325-482, at 372.

${ }^{52}$ Although these concepts could be distinguished in some respect, this paper uses the terms "powers" and "competences” interchangeably.

${ }^{53}$ As the ICJ stated: "It must be acknowledged that its members, by entrusting certain functions to it, with the attendant duties and responsibilities, have clothed it with the competence required to enable those functions to be effectively discharged.” Reparation for Injuries Suffered in the Service of the United Nations, Advisory Opinion of 11 Apr. 1949, [1949] ICJ Rep. 174, at 179. See generally Dan Sarooshi, International Organizations and Their Exercise of Sovereign Powers (Oxford: OUP 2005), and the discussion below.

${ }^{54}$ Heidrun Abromeit and Tanja Hitzel-Cassagnes, 'Constitutional Change and Contractual Revision: Principles and Procedures', (1999) 5 European Law Journal 23-44, at 30-31, explaining that there are two kinds of contractual relationships: "one is the firm establishment of a principal-agent relationship, agreed upon by mutual consent and to be cancelled the moment one of the parties of the contract has demonstrably violated its terms. The other is the agreement between 'equals' to act in unison, without one of them necessarily acting the part of 'agent.'. [...] In an ideal—or hypothetical—world, a constitution should combine both aspects of the contract, in fact it should be a 'meta-contract' laying down the basic rules for further contracting of both variants. In practice, however, the requirement of unanimity marks the essential difference between contract and constitution.”

${ }^{55}$ Such a collective conferral can be distinguished from individual conferrals of powers. See Dan Sarooshi, 'Conferrals by States of Powers on International Organizations: The Case of Agency’, (2004) 74 BYIL 291-332.

${ }^{56}$ As Kelsen stated: "The juristic person, in the narrower sense of the term, is nothing but the personification of an order regulating the behavior of several individuals, so to speak - the common point of imputation for all those human acts which are determined by the order.” Hans Kelsen, General Theory of Law \& State (New Brunswick: Transaction Publishers 2005), at 99 .

${ }^{57}$ On the formation of the volonté distincte see generally Evelyne Lagrange, La représentation institutionnelle dans l'ordre international. Une contribution à la théorie de la personnalité morale des organisations internationales (The Hague: Kluwer 2002), 8ff.
} 
whole that is the international organization. ${ }^{58}$ In fact, the constituent instruments of many international organizations make an explicit textual distinction between the "contracting parties" and "member States" or "members". ${ }^{59}$ While the former term indicates what the traditional law of treaties calls the “original parties", the latter term designates the mode of participation associated with international organizations. ${ }^{60}$ The distinction between member States and contracting parties has thereby more than only terminological significance. Only at the moment of the creation of the organization (and its possible termination) do the States that founded the international organization act as contracting parties; during the life of the organization they are member States. An international organization is thus not founded by its member States but by the contracting parties to its constituent instruments acting collectively. ${ }^{61}$

In the process of constitution-making, the contracting parties disappear behind the constitutional veil of the organization. However, it is important to note that by becoming members of the international organization, States do not give up their legal personality under national or international law. By conferring powers to the international organization, they merely limit their own autonomy in order to allow the international organization to take decisions independently, ${ }^{62}$ but continue to co-exist side-by-side with the international organization to the extent that it has autonomy. ${ }^{63}$ The internal autonomy from its member States thereby manifests itself externally by the impermeability of the international organization's legal order. ${ }^{64}$ While legal personality is thus a

\footnotetext{
${ }^{58}$ The term "member" is derived from the Latin word "membrum", which stands for "parts of the body". See Niels Blokker, 'International Organizations and their Members: "International Organizations Belong to All Members and to None" Variations of a Theme', (2004) 1 IOLR 139-161, at 139.

${ }^{59}$ This is not to say that there are no exceptions, such as the WTO, among the large variety of international organizations. However, this paper uses the terminological distinction between "contracting parties" and "member States" to illustrate the different roles that States play outside and inside the legal order of an international organization at different stages of its life span.

${ }^{60}$ See Shabtai Rosenne, 'Is the Constitution of an International Organization an International Treaty', (1966) 12 Communicazioni e Studi 21-89 at 51-52; Niels Blokker, 'International Organizations and their Members: "International Organizations Belong to All Members and to None” - Variations of a Theme’, (2004) 1 IOLR 139-161, at 140-141.

${ }^{61}$ In a similar vein, Blokker Niels Blokker, 'International Organizations and their Members: "International Organizations Belong to All Members and to None” - Variations of a Theme’, (2004) 1 IOLR 139-161, at 140.

${ }^{62}$ The Permanent Court of International Justice (PCIJ) explained the interplay between contractual freedom and sovereign autonomy in the Wimbledon case as follows: "The Court declines to see in the conclusion of any Treaty by which a State undertakes to perform or refrain from performing a particular act an abandonment of its sovereignty. No doubt any convention creating an obligation of this kind places a restriction upon the exercise of the sovereign rights of the State, in the sense that it requires them to be exercised in a certain way. But the right of entering into international engagements is an attribute of State sovereignty.” Case of the S.S. Wimbledon, Judgment of 17 Aug. 1923, [1925] PCIJ Ser. A, Vol. 1, at 25. For a discussion see Jan Klabbers, 'Clinching the Concept of Sovereignty: The Wimbledon Redux', (1998) 3 Austrian Review of International and European Law 345-367.

63 Autonomy means literally the "power to make one’s own law". However, instead of "law-making" the broader term "decision-making" is used here to indicate the capacity of international organizations to act independently. With regard to the coexistence of an international organization and its members Lagrange notes: "La coexistence de l'organisation et de ses membres dans l'ordre juridique international résulte en effet du principe général de non-transitivité qui règle leurs rapports.” Evelyne Lagrange, La représentation institutionnelle dans l'ordre international. Une contribution à la théorie de la personnalité morale des organisations internationales (The Hague: Kluwer 2002), 45.

${ }^{64}$ Since international organizations are neither open structures that blend with general international law, nor closed impermeable actors in the same way as States, Brölmann speaks of "transparency" of international organizations. See Catherine Brölmann, The Institutional Veil in Public International Law: International Organisations and the Law of Treaties (Oxford: Hart Publishing 2007), 29-33. However, while international organizations evidently play a dual role in the law of treaties, as independent actors that can conclude international agreements and as fora for the treaty negotiations of States, the law of responsibility, as discussed in Part 2 of this paper, presupposes only closed actors with impermeable (partial) legal orders. Brölmann interestingly concedes that the "dual imagery - which results in a degree of transparency in the institutional
} 
matter of factual or constitutional existence resulting from initial contractual arrangements, ${ }^{65}$ autonomy is a matter of degree that depends on the constituent instruments in their constitutional dimension. ${ }^{66}$ In other words, legal personality is a receptacle for the varying degrees of power or competence of an international organization, which enable it to be the bearer of rights and obligations at the internal and international plane. By recognizing the dual nature of the constituent instruments, the establishment of an international organization as an autonomous legal person can hence be reconciled with its contractual origins in the law of treaties. ${ }^{67}$

\subsection{THE SINGLE NATURE OF THE SECONDARY LAW}

On the basis of its constituent instruments, an international organization will embark on a life of its own and will develop its own legal and political order. The dynamic interaction of an international organization with the subjects of its legal order, including its member States and other entities or individuals such as employees, may thereby give rise to a variety of legal acts that are generally summarized under the term secondary law of the international organization, because they emanate from the constituent instruments as the primary source of rights and obligations within the legal order of the organization. However, although this secondary law is the manifestation of an international organization's autonomy in decision-making, and thus internal to its constitutional order, the legal nature of the acts of international organizations is contested and more often than not considered part of international law due to its contractual origins. ${ }^{68}$

veil that clothes organisations - exists in the minds of the international lawyers and politicians.” (Ibid., at 30) As the ambiguous term "rules of the organization" illustrates, the ILC is not an exception in this regard.

${ }^{65}$ In this sense, the evolution of the concept of "objective regimes", which was initially mainly applied to territorial boundaries, could be significant with regard to the legal personality of international organizations. As Paul Reuter observes, "the various theoretical views followed on this point by the International Law Commission [...] regard certain legal effects not as a consequences of the treaty itself but of the situation established by the treaty." Paul Reuter, Introduction to the Law of Treaties (London: Kegan Paul International), at 128 [original emphasis]. For a discussion see Catherine Brölmann, The Institutional Veil in Public International Law: International Organisations and the Law of Treaties (Oxford: Hart Publishing 2007), 115.

${ }^{66}$ The ICJ's well-known statement that the United Nations has a "large measure of international legal personality” is thus misleading; see Reparations for Injuries Suffered in the Service of the United Nations, Advisory Opinion of 11 Apr. 1949, [1949] ICJ Rep. 174, at 179. For a critical assessment Philippe Sands and Pierre Klein, Bowett's Law of International Institutions (London: Sweet \& Maxwell 2009), 474ff., and Nigel White, The Law of International Organisations (Manchester: Manchester University Press 2005), 30ff. In its 1996 Advisory Opinion of the Legality of the Use of Nuclear Weapons the ICJ rightly put more emphasis on the gradual nature of autonomy as opposed to legal personality: "But the constituent instruments of international organizations are also treaties of a particular type; their object is to create new subjects of international law endowed with certain autonomy, to which the parties entrust the task of realizing common goals.” Legality of the Use by a State of Nuclear Weapons in Armed Conflict, Advisory Opinion of 8 July 1996, [1996] ICJ Rep. 226, at 75 (para. 19).

${ }^{67}$ As Rosenne summarizes: "However, the doctrinal literature discloses a significant distinction between the theories according to which the constitution itself is a treaty (and, as seen generally a species of traité-loi) pure and simple, and a more sophisticated conception in which the element of the treaty appears merely as the presupposition of the organization, the foundation on which the superstructure, the Constitution, and even more constitutional practices and the dynamism released by the functioning of the organization, are based." Shabtai Rosenne, 'Is the Constitution of an International Organization an International Treaty', (1966) 12 Communicazioni e Studi 21-89. See also Maurice Hauriou, 'La théorie de l'institution et de la fondation', (1925) 4 Cahiers de la Nouvelle Journée, stating at 36 that "toutes les fois que d'un contrat, d'un pacte, d'un traité, résulte la création d'un corps constitué quelconque, il convient d'admettre qu'une opération de fondation s'est mêlée à l'opération contractuelle."

${ }^{68}$ For references see the more specific sections 1.2.1 "Acts of the Organization" and 1.2.2 "Established Practice of the Organization” of this paper. 
Considering the dual nature of the constituent instruments, it is submitted in this paper that the continued importance of the constituent instruments of an international organization does not justify the characterization of this secondary law as international law. While the constituent instruments are a contract at the moment of the creation of the organization, they serve as a constitution during the life span of the organization, operating as "power maps" or "official blueprints for the uses of public power ${ }^{\prime 69}$ in the internal and international relations of an international organization. ${ }^{70}$ As a result of a conferral of powers, an international organization can act autonomously so that its secondary acts form part of its internal constitutional law (1.2.1). The secondary law of the organization does not only include written rules but also internal customary law resulting from the established practice of the organization, which is not to be confounded with the subsequent practice of the contracting parties to the constituent instruments (1.2.2). Considering that the autonomy of international organizations is limited, as often described by the principle of specialty, an international organization may exercise its competences concurrently with its (member) States in order to fulfill its functions. However, the interaction of an international organization's institutional order with other national or international orders does not change the fact that the secondary law of the international organization itself is of a single internal nature.

\subsubsection{Acts of the Organization}

The secondary law of international organizations may be comprised of acts with diverse denominations - ranging from resolutions, decisions, recommendation, declarations, guidelines, regulations, directives, or standards - made by different organs and addressed to member States, organs or individuals. In light of this heterogeneity of legal instruments, it does not come as a surprise that the legal nature of the acts of international organizations is even more controversial than that of their constituent instruments. Most scholars argue that the acts of international organizations are part of international law, due to their contractual origins and the fact that they often regulate relations between States. As one of the first authors, Anzilotti observed that the rules of procedure of the Council and the Assembly of the League Nations were of the same legal nature as the Covenant of the League of Nations, ${ }^{71}$ a finding that was later confirmed by Jessup for the "parliamentary law" of other

\footnotetext{
${ }^{69}$ Keith G. Banting and Richard Simeon, Redesigning the State: The Politics of Constitutional Change (Toronto UP 1985), at 3. As Virally succinctly explains: "La fonction d'une Organisation internationale constitue sa justification et celle de toute son activité, sa ratio, aux deux sens du terme: raison d'être et limitation. On le constate à propos de sa structure aussi bien qu'à l'égard de sa compétence et de ses pouvoirs.” Michel Virally, 'La notion de fonction dans la théorie de l'organisation internationale', in Suzanne Bastid et al., Mélanges offerts à Charles Rousseau: La communauté internationale (Paris: Editions A. Pédone 1974), 277-300, at 291.

${ }^{70}$ As Lagrange notes: "Pour autant que ses compétences le lui permettent, l'organisation internationale peut se tourner vers les tiers en manifestant sa qualité de sujet distinct des membres qui la composent et cependant dévoué à leur intérêt commun: la représentation le cède à la coexistence dans les rapports conventionnels avec les tiers." Evelyne Lagrange, $L a$ représentation institutionnelle dans l'ordre international. Une contribution à la théorie de la personnalité morale des organisations internationales (The Hague: Kluwer 2002), 44.

${ }^{71}$ See Dionisio Anzilotti, Cours de droit international (Paris: Recueil Sirey 1929), 295-296.
} 
international organizations. ${ }^{72}$ Other authors such as Cahier, Kolasa, or Skubiszewski consider the acts of international organizations as being separate from international law, but still as a "distinct source of the law of nations". ${ }^{73}$ A third category of scholars, in particular international institutional lawyers, recognize that the secondary law is part of the internal legal order of an international organization. However, they generally limit this observation to the norms pertaining to the functioning of the organization, ${ }^{74}$ and speak of "external effects" when the acts of international organizations give rise to rights and obligations for States. ${ }^{75}$ As Benzing summarizes the current state of the debate with reference to the treaty nature of the constituent instruments, there is "growing consensus that secondary rules promulgated by international organizations today form part of the sources of international law.,76

In view of the constitutional nature of the constituent instruments, it is suggested here that the secondary law made by international organizations is not a distinct source of the law of international law but a distinct source of law in the internal legal order of the organization. ${ }^{77}$ By conferring competences to an international organization, the wills of States are integrated into the corporate will of the organization. Accordingly, the law of treaties is irrelevant for the international organization's autonomous decision-making: the normative force of the acts of its organs depends on the legal order of the organization. ${ }^{78}$ In fact, most international lawyers would agree that it is in their capacity as

\footnotetext{
${ }^{72}$ See Philip C. Jessup, 'Parliamentary Diplomacy - An Examination of the Legal Quality of the Rules of Procedure of Organs of the United Nations', (1965-I) Recueil des Cours, at 204; also Philip C. Jessup, 'International Parliamentary Law', (1957) 51 AJIL 396-402. For more recent proponents of this view see Rudolf Bernhardt, 'Qualifikation und Anwendungsbereich des internen Rechts internationaler Organisationen’, (1973) 12 Berichte der Deutschen Gesellschaft für Völkerrecht 7-42; Malcolm Shaw, International Law (Cambridge: CUP 2003), at 1199.

${ }^{73}$ See Krzysztof Skubiszewski, 'Enactment of Law by International Organizations', (1965-1966) 41 BYIL 198-274, at 245 [emphasis added]; Philippe Cahier, 'Le droit interne des organisations internationales', (1963) 67 Revue général du droit international public 563-602; Jan Kolasa, 'La notion de droit interne des organisations internationales', (1970) 3 Polish Yearbook of International Law 95-110; C Tomuschat 'Obligations Arising for States Without or Against Their Will' (1993) 241 RdC 195-374, at 325.

${ }^{74}$ See Henry G. Schermers and Niels M. Blokker, International Institutional Law: Unity within Diversity (Boston: Martinus Nijhoff Publishers 2003), 752ff (para. 1196ff); Markus Benzing, International Organizations and Institutions - Secondary Law', (2007) MEPIL; C.F. Amerasinghe, Principles of the Institutional Law of International Organisations (Cambridge: CUP 2005), 271ff.; Lazar Focsaneanu, 'Le droit interne de l’Organisation des Nations Unies', (1957) 3 Annuaire français de droit international 315-349; Herbert Miehsler, 'Qualifikation und Anwendungsbereich des internen Rechts internationaler Organisationen', (1973) 12 Berichte der Deutschen Gesellschaft für Völkerrecht 47-83; Riccardo Monaco, 'Le caractère constitutionnel des actes institutifs d'organisations internationales', in Mélanges offerts à Charles Rousseau: La Communauté Internationale (Paris: Editions A. Pédone 1974), 153-172.

${ }^{75}$ These scholars are faced with the problem that even matters that clearly pertain to the functioning of the organization, such as budgetary affairs or the creation of new organs, give rise to rights and obligations for States, albeit of a more procedural than substantive nature. One commentator tries to solve this problem by noting that the decisional powers of the General Assembly extend to "semi-external matters such as the budget, or admission, suspension and expulsion of members". Marko Divac Öberg, 'The Legal Effects of Resolutions of the UN Security Council and General Assembly in the Jurisprudence of the ICJ', (2006) 16 EJIL 879, at 883.

${ }^{76}$ Markus Benzing, 'Secondary Law of International Organizations', MEPIL (March 2007), para. 2 [original emphasis].

${ }^{77}$ In a similar vein, Philippe Sands and Pierre Klein, Bowett's Law of International Institutions (London: Sweet \& Maxwell 2009), at 448ff., distinguishing between the internal law of the organization (the constituent instruments, relevant decisions and resolutions of the organization, and established practice) and general international law (including secondary legislations of other international organizations).

${ }^{78}$ Lagrange explains : "Pour une conception formaliste de la personnalité morale, peu importe l'autorité et l'effectivité des décisions de l'organisation internationale. La force juridique de l'acte est étrangère à sa qualification ou, de qui revient au même, à son imputation à tel ou tel auteur. Par suite, l'existence de l'organisation est indifférente à la force juridique des actes qu'elle prend. Les problématiques se recoupent dans la stricte mesure où le consentement du destinataire conditionne l'entrée en vigueur de l'acte et sa force contraignante." Evelyne Lagrange, La représentation institutionnelle dans l'ordre
} 
constitutions, and not as contracts, that the constituent instruments are generally recognized as the highest source of rights and obligations in the legal order of an international organization. ${ }^{79}$ As Judges Spender and Fitzmaurice rightly state, "the fact that an act is done under an authority contained in an instrument which is itself a treaty [...] does not per se give the resulting act a treaty character." ${ }^{, 80}$ This is most apparent in cases of majority decision-making, which results in legal acts without, and possibly even against, the explicit consent of its member States, ${ }^{81}$ but also extends to unanimous decisions taken by organs of international organizations, which do also not follow the traditional modes of treaty-making. ${ }^{82}$ Consequently, the secondary law of international organizations, resulting from the corporate will of the international organization, is internal law of its legal order, and in this sense not different from the internal law of States. The role of the law of treaties is limited to illustrating that this internal law is res inter alios $a c t a,{ }^{83}$ or, more broadly speaking, of a factual nature in other legal orders. ${ }^{84}$

Unlike the constitutional orders of States, however, the constitutional order of international organizations are often said to be incomplete, ${ }^{85}$ or - as expressed by the International Court of Justice (ICJ) - limited by the "principle of speciality". ${ }^{86}$ Yet, the reference to the principle of speciality illustrates that the difference between the constitutions of States and international organizations is

international. Une contribution à la théorie de la personnalité morale des organisations internationales (The Hague: Kluwer 2002), 38.

${ }^{79}$ See Rudolf Bernhardt, 'International Organizations - Internal Law and Rules’, (1983) 5 MEPIL 143-145, at 143. When considering the Covenant of the League of Nations but also other foundational treaties, McNair already stated in 1930 that "its seems to me that these constitutional treaties [...] create a kind of public law transcending in kind and not merely in degree the ordinary agreements between States." Arnold D. McNair, "The Functions and Differing Legal Character of Treaties', (1930) 11 BYIL 100-118, at 112.

${ }^{80}$ Joint Dissenting Opinion in the South-West Africa cases (Preliminary Objections), Judgment of 21 Dec. 1962, [1962] ICJ Rep. 465, at 491. See also the statements at 475 where the view is taken that the notion of treaty is "not an unlimited one", and at 476 that it is a fallacy to identify "the idea of an international agreement with any act or instrument embodying, or giving rise to, international organizations, or which contains or involves an 'international engagement'."

${ }^{81}$ As Skubiszewski notes: "For the authorship of these acts must even more definitely be attributed to the organization as a corporate person distinct from the member States.” Krzysztof Skubiszewski, 'Enactment of Law by International Organizations', (1965-1966) 41 BYIL 198-274, at 243.

${ }^{82}$ As Carré de Malberg observes with regard to the State: "Il se peut en effet que les individus qu'à rapprochés la poursuite d'un même bût aient contracté une association dont le fonctionnement doit dépendre des volontés respectives de chacun d'eux : dans ce case, la volonté commune, destiné à réaliser le but commun, n’est pas autre chose que la somme des volontés individuelles exprimées soit à l'unanimité, soit à la simple majorité des voix par les membres mêmes du groupe.” Raymond Carrée de Malberg, Contribution à la théorie générale de l'Etat (Paris : Sirey 1920/1962), t. I, para. 12.

${ }^{83}$ See Evelyne Lagrange, La représentation institutionnelle dans l'ordre international. Une contribution à la théorie de la personnalité morale des organisations internationales (The Hague: Kluwer 2002), at 47, stating : "Il n’y là rien que de très connu: le principe structurant pacta tertiis nec nocent nec prosunt voue nécessairement l'ordre international au pluralisme. [...] Or, constituant un nouveau sujet de droit, le traité fondateur isole les ordres juridiques autrement que ne le font les traités dépourvus de cet effet."

${ }^{84}$ See Certain German Interests in Polish Upper Silesia, Judgment of 25 May 1926, PCIJ Ser. A, No. 7, at 19, finding: "From the standpoint of International Law and of the Court which is its organ, municipal laws are merely facts which express the will and constitute the activities of States, in the same manner as do legal decisions or administrative measures. The Court is certainly not called upon to interpret the Polish law as such; but there is nothing to prevent the Court's giving judgment on the question whether or not, in applying that law, Poland is acting in conformity with its obligations towards Germany under the Geneva Convention.”

${ }^{85}$ See Henry G. Schermers and Niels M. Blokker, International Institutional Law: Unity within Diversity (Boston: Martinus Nijhoff Publishers 2003), 720 (para. 1141); Pierre Klein, 'International Organizations and Institutions - Internal Law and Rules', (2006) MEPIL, at para. 3.

${ }^{86}$ The ICJ stated that "international organizations do not, unlike States, possess a general competence, but are governed by the 'principle of specialty', that is to say, they are invested by the States which create them with powers, the limits of which are a function of the common interests whose promotion those States entrust to them." Legality of the Use by a State of Nuclear Weapons in Armed Conflict, Advisory Opinion of 8 July 1996, [1996] ICJ Rep. 66, at 78 (para. 25). 
rather a matter of degree than of kind. ${ }^{87}$ Whereas States largely retain their competences when establishing an international organization, the people, as the pouvoir constituant at the national level, have ceded most of their competences to the pouvoir constitue that is the State. As a result of this transfer of powers to the State, State constitutions usually give rise to higher levels of identity and loyalty paid to the State polity in question, which is often characterized in terms of stronger constitutional traditions. ${ }^{88}$ As opposed to a weak constitution, a strong constitution "constitutes a society and not just an organization, a constitution which is basal and not only bureaucratic." ${ }^{" 89}$ To which degree a polity has autonomy from its constituent components, whether people or States, ultimately depends on the allocation of competences between the entities in question. ${ }^{90}$ It is not surprising that the European Court of Justice has therefore repeatedly insisted that the Community Treaty has "created its own legal system", ${ }^{91}$ which "constitutes a new legal order of international law", 92 while other international organizations normally emphasize the autonomy of their partial legal orders less emphatically.

States are generally rather reluctant to confer sovereign powers to international organizations, which may limit their own autonomous decision-making. As a result, most international organizations only have the competences to ensure their effective functioning as a matter of constitutional existence. Such competences typically include the regulation of budgetary matters, the adoption of rules of procedure, the creation of subsidiary organs, the admission or expulsion of members, and employment relations. ${ }^{93}$ Few international organizations have more far-reaching competences to change the rights and obligations of their member States in their respective institutional orders. Besides the UN Security Council and the European Union (EU), organizations such as the Organization for Economic Cooperation and Development (OECD), European Free Trade Association (EFTA), International Civil

\footnotetext{
${ }^{87}$ As White observes, "while organisations normally do not have the same rights and duties as States, the 'complete' international legal person, they may, on occasions match them in certain areas, and indeed surpass them.” Nigel White, The Law of International Organisations (Manchester: Manchester University Press 2005), at 69. Focsaneanu notes that "[l]es Nations Unies forment une société moins intégrée que les Etats”, while analyzing the differences in detail. Lazar Focsaneanu, 'Le droit interne de l'Organisation des Nations Unies', (1957) 3 Annuaire français de droit international 315-349, at 339.

${ }^{88}$ See Nigel White, The Law of International Organisations (Manchester: Manchester University Press 2005), stating at 16; James Crawford, 'Multilateral Rights and Obligations', (2006-II) 319 Recueil des Cours 325-482, at 372ff.

${ }^{89}$ James Crawford, 'Multilateral Rights and Obligations', (2006-II) 319 Recueil des Cours 325-482, at 372.

${ }^{90}$ Even national constitutions show wide divergences in their respective constitutional set-ups, not only in the forms of government chosen but also in the design of a particular form of government such as democracy. While in many democracies, the people only directly participate in government at elections, more direct democracies such Switzerland regularly involve the people in the form of referenda.

${ }^{91}$ Costa v. ENEL, 6/64, [1964] ECR 585, at 593.

${ }^{92}$ Van Gend en Loos, 26/62, [1963] ECR 1, at 12.

${ }^{93}$ In fact, it was the need for a coherent body of law covering the relations between the organization and its employees that has led to increasing recognition of the notion of "internal law" of international organization since the 1920s. If the national laws of member States had been applicable to the employment relations within an international organisation, national courts would have been competent to hear disputes on staff matters and potentially other subjects. As a result, the international organization would have been subjected to the control of individual member States, which would have gone against their sovereign equality. See Henry G. Schermers and Niels M. Blokker, International Institutional Law: Unity within Diversity (Boston: Martinus Nijhoff Publishers 2003), 720 (para. 1142); See Pierre Klein, 'International Organizations and Institutions - Internal Law and Rules', (2006) MEPIL, at para. 2. On the internal matters of international organizations see generally Henry G. Schermers and Niels M. Blokker, International Institutional Law: Unity within Diversity (Boston: Martinus Nijhoff Publishers 2003), 729 (para. 1154); Philippe Sands and Pierre Klein, Bowett's Law of International Institutions (London: Sweet \& Maxwell 2009), 537.
} 
Aviation Organization (ICAO) or the World Health Organization (WHO) are well-known examples. Yet, the EU is so far the only example of an international organization that has become "the sole place for the lawful exercise of conferred powers” in substantive matters such as trade or customs, ${ }^{94}$ resulting in the disappearance of member States behind the constitutional veil of the organization. However, even the constituent instruments of the EU include various areas in which the organization only has shared or parallel competences with its member States. ${ }^{95}$

It can therefore be concluded that international organizations generally exercise their competences concurrently with States, which results in a complex international reality. In other words, the corporate act of the international organization still needs to be complemented by an act of the State, as an expression of its individual consent. ${ }^{96}$ This individual consent may be necessary in the context of implementation of the act of the international organization at the national level, such as in case of UN Security Council resolutions under Chapter VII or EU directives, or may require ratification of international conventions. The International Labour Organization (ILO), for example, is known for solving substantive questions by drafting multilateral conventions to be concluded by their members, and sometimes even by non-members, which are "inseparable from its constituent instrument and from its very existence." ${ }^{, 97}$ The act of an international organization may thus give rise to other acts by its member States acting in their capacity as States under national or international law, so that the result will be a complex legal act. ${ }^{98}$ However, this plurality of legal orders should not distract from the fact that the act of the organization itself, as the outcome of its corporate will, has a single and internal legal nature.

\subsubsection{Established Practice of the Organization}

The internal secondary law of international organizations may also comprise customary rules resulting from the "established practice of the organization", whose internal nature has been contested with

\footnotetext{
${ }^{94}$ Sarooshi distinguishes between 'partial transfers' and 'full transfers' of sovereign powers to international organizations. While the WTO is an example for the former category, the EU illustrates the latter. Dan Sarooshi, International Organizations and Their Exercise of Sovereign Powers (Oxford: OUP 2005), 69ff.

${ }^{95}$ For a general overview of the allocation of competences between the European Union and its member States after the Treaty of Lisbon see Allan Rosas and Lorna Armati, EU Constitutional Law. An Introduction (Oxford: Hart Publishing 2010), 17-26.

${ }^{96}$ As Lagrange notes: “Si les actes sont parfaits dès leur adoption, leur imputation à l'organisation à titre d'actes collectifs procédera du dépassement des manifestations individuelles de volonté. Dans le contraire, la qualification d'acte complexe pourra venir bousculer la dichotomie opposant des actes corporatifs aux actes conventionnels: l'ordre juridique de l'organisation s'étend au-delà des actes corporatifs." Evelyne Lagrange, La représentation institutionnelle dans l'ordre international. Une contribution à la théorie de la personnalité morale des organisations internationales (The Hague: Kluwer 2002), 44.

${ }^{97} \mathrm{Mr}$. Virally (on behalf of France) further stated that "[t]reaties of that kind should be governed by special rules as to their interpretation, validity and application." Official Records of the United Nations Conference on the Law of Treaties, First Session (Summary records of the plenary meetings and of the meetings of the Committee of the Whole), A/CONF.39/C.1/SR.8 (1968). Article 5 of the VCLT accordingly refers to such treaties as being concluded "within an international organization". The functions of many international organizations include the elaboration and conclusion of topic-specific multilateral conventions. See Philippe Sands and Pierre Klein, Bowett's Law of International Institutions (London: Sweet \& Maxwell 2009), at 281, giving different examples.

${ }^{98}$ On the different roles that States can play in the creation of a complex legal act see Evelyne Lagrange, La représentation institutionnelle dans l'ordre international. Une contribution à la théorie de la personnalité morale des organisations internationales (The Hague: Kluwer 2002), 38.
} 
reference to the law of treaties in a similar way as the acts of the organization in general. Indeed, the term "established practice” made its first appearance at the Vienna Conference on the Law of Treaties in an amendment proposed by the British delegation to Article 4 of the 1969 VCLT on the "rules of the of the organization". ${ }^{99}$ Although the Drafting Committee decided not to alter the original text of the ILC draft Articles on the Law of Treaties, despite the support of several delegations ${ }^{100}$ and representatives of international organizations, ${ }^{101}$ it made clear that the term "rules" in Article 4 applied both to written and unwritten customary rules. ${ }^{102}$ Nevertheless, although the ILC seemed to acknowledge the legal nature of established practice as a source of law of the organization, it remains very much debated whether "established practice" is to be understood as the practice of the organs of the organization, or as "subsequent practice" of the contracting parties in the meaning of Article 31 (3) lit. b) of the 1969 VCLT. ${ }^{103}$

The question of the legal nature of the "established practice" of the organization thus primarily arises in connection with the interpretation of the constitutive instruments. The particular significance of the practice of the organization for interpretative purposes is due to the fact that the contracting parties of the constituent instruments cannot foresee possible lacunae in the constitutional text at the time of drafting. As a result of the practice of the organization, the constituent treaties will often evolve and change in a manner that may go beyond the original wording of their texts and may lead to disputes over their interpretation. ${ }^{104}$ These controversies usually pertain to the allocation of competences between States and the organization, between its organs, or its member States, and have resulted in what Judge Alvarez called in the Admission Advisory Opinion of the ICJ "constitutional interpretation”. ${ }^{105}$ This constitutional interpretation can be distinguished from traditional treaty interpretation in that it puts more emphasis on the institutional practice of the organization in

\footnotetext{
${ }^{99}$ As Sir Francis Vallet noted on behalf of the United Kingdom "the words 'rules' [in draft Article 4 of the VCLT] was sufficient, but there was a tendency to interpret it in a limited sense referring to the written rules or possibly regulations, but not including practices established by usage, etc." See Official Records of the United Nations Conference on the Law of Treaties, First Session (Summary records of the plenary meetings and of the meetings of the Committee of the Whole), A/CONF.39/C.1/SR.8 (1968).

${ }^{100}$ See, for instance, the statement of the Indian delegation, Official Records of the United Nations Conference on the Law of Treaties, First Session (Summary records of the plenary meetings and of the meetings of the Committee of the Whole), A/CONF.39/C.1/L.39 (1968).

${ }^{101}$ See the statements of the FAO (A/CONF.39/C.1/SR.8 (1968)), Council of Europe (A/CONF.39/C.1/SR.9 (1968)) and WHO (A/CONF.39/C.1/SR.10 (1968)), in Official Records of the United Nations Conference on the Law of Treaties, First Session (Summary records of the plenary meetings and of the meetings of the Committee of the Whole).

${ }^{102}$ Official Records of the United Nations Conference on the Law of Treaties, First Session (Summary records of the plenary meetings and of the meetings of the Committee of the Whole A/CONF.39/C.1/SR.28 (1968). See also ILC Report, Fifteenth Session, UN Doc. A/CN.4/163 (1963), at 213: “The term 'established rules of the organization' is intended here, as in article 18, paragraph $1(a)$, to embrace not only the provisions of the constituent instrument or instruments of the organization but also the customary rules developed in its practice.”

${ }^{103}$ In that sense, the nature of the practice of international organizations is like the nature of their legal acts, an abiding bone of contention among experts. For an overview of the debate see Tetsuo Sato, Evolving Constitutions of International Organizations (The Hague/London/Boston: Kluwer Law International, 1996).

${ }^{104}$ As Henry G. Schermers and Niels M. Blokker, International Institutional Law: Unity within Diversity (Boston: Martinus Nijhoff Publishers 2003), observe at 840 (para. 1344): “As long as their interpretations remain unchallenged, the members will continue to interpret their obligations in the manner in which they think they ought to be interpreted and the organs will continue to exercise the competences to which they think they are entitled. Sometimes the original interpretation by the applicant is challenged. This challenge created a dispute between the two parties."

${ }^{105}$ Admission of a State to the United Nations (Charter, Art. 4), Advisory Opinion of 28 May 1948, [1948] ICJ Rep. 57, at 67-72.
} 
conjunction with principle of effectiveness or effet utile than on other elements of interpretation such as the literal meaning of the or travaux préparatoires of the constituent instruments. ${ }^{106}$ This shift of emphasis is thereby justified by the need to weigh the conflict of interests of individual states - which is the subject of traditional interpretation - against the interest of the collectivity that is the organization itself. ${ }^{107}$

Various international tribunals have considered the "established practice" of the organization as an important parameter in appraising whether an internal legal act of the organization was made in conformity with the procedures laid down in the constitutive instrument and for which the latter needed to be interpreted. The best-known example is probably the 1971 Namibia Advisory Opinion in which the ICJ found that an established body of practice forms an integral part of the rules of the organization when considering the effect of abstentions by permanent members of the Security Council in the voting procedure. ${ }^{108}$ However, more often than judicial organs, the political organs of international organizations are in charge of interpretation, and judicial measures or arbitration are only a secondary option. ${ }^{109}$ For the issue of compatibility with the constituent instrument of a legal act of the organization is frequently brought by the majority within the organ concerned in reaction to the concrete situation presented to it. As was noted with regard to the interpretation of the constitutions of international financial institutions, "there develops in various respects what one may describe first as an esprit de corps, then as practice and, finally, as binding custom”, even in the absence of judicial control. ${ }^{110}$ Although the political organs of international organization consider the traditional rules of treaty interpretation, they generally do so with certain constitutional variations. ${ }^{111}$

It could thus be argued that the application of the principle of organizational practice as used in the interpretation of constitutions "clearly diverges" from that of 'subsequent practice' of the parties in relation to ordinary treaties. ${ }^{112}$ As in the case of written secondary law of international

\footnotetext{
${ }^{106}$ See generally C.F. Amerasinghe, Principles of the Institutional Law of International Organisations (Cambridge: CUP 2005), 59.

107 See Shabtai Rosenne, 'Is the Constitution of an International Organization an International Treaty', (1966) 12 Communicazioni e Studi 21-89, at 68.

${ }^{108}$ Legal Consequences for States of the Continued Presence of South Africa in Namibia (South West Africa), Advisory Opinion of 20 June 1971, [1971] ICJ Rep. 16, at para. 22. Other examples of constitutional interpretation by the ICJ include the Reparations for Injuries Suffered in the Service of the United Nations, Advisory Opinion of 11 Apr. 1949, [1949] ICJ Rep. 174; the Certain Expenses of the United Nations, Advisory Opinion of 20 July 1962, [1962] ICJ Rep. 151, or Legal Consequences of the Construction of a Wall in the Occupied Palestinian Territory, Advisory Opinion of 9 Jul. 2004, [2004] ICJ Rep. 136, at 25-28). See also the practice of the UN administrative tribunals in Fernandez-Lopez, UNAT Judgment No. 254 [1980]; Rosecu, ILOAT Judgment No. 431 [1980] at 7.

${ }^{109}$ See C.F. Amerasinghe, Principles of the Institutional Law of International Organisations (Cambridge: CUP 2005), at 25; and Henry G. Schermers and Niels M. Blokker, International Institutional Law: Unity within Diversity (Boston: Martinus Nijhoff Publishers 2003), at 852 (para. 1355).

${ }^{110}$ F.A. Mann, 'The 'Interpretation' of the Constitutions of International Financial Organizations', (1968-1969) BYIL 1-20, at 18.

${ }^{111}$ Ibid., at 18. See also Michael Wood, 'The Interpretation of Security Council Resolutions, (1998) 2 Max Planck Yearbook of United Nations Law 73-95, at 95, stating that "given their essentially political nature and the way they are drafted, the circumstances of the adoption of the resolution and such preparatory as exists more often be of greater significance than in the case of treaties. In general, less importance should attach to the minutiae of language. And there is considerable scope for authentic interpretation by the Council itself."

${ }^{112}$ Elihu Lauterpacht, 'The Development of the Law of International Organization by the Decisions of International Tribunals', (1976-IV) 152 Recueil des Cours 377-478, at 458. But also Shabtai Rosenne, 'Is the Constitution of an International Organization an International Treaty’, (1966) 12 Communicazioni e Studi 21-89,
} 
organizations, the distinction can be made along contractual and constitutional lines of argument. While the principle of subsequent practice in the law of treaties is based on the premise that all parties to the treaties participate in its reinterpretation, organizational practice may often include only a fraction of the actual membership or original founders of the organization. ${ }^{113}$ Moreover, the practice of the organization is not only comprised of acts by the members of the organization, but also by the collective acts of its organs, and frequently even against dissenting opinions. ${ }^{114}$ If only the organs or specific member States are involved in the emergence of this practice, it is likely to be limited to the internal constitutional sphere of the organization. In contrast, if all member States participate - for instance in a plenary organ or as a result of a binding decision - constitutional and contractual interpretation overlap, and the internal practice of the organization may have contractual effects at the level of treaty interpretation. ${ }^{115}$ The point of interception hereby lies in the intention of the parties, which limits both methods of interpretation to the object and purpose of the constituent instruments. ${ }^{116}$ Neither the principle of effectiveness nor subsequent practice of the parties can lead to an explicit derogation from the treaty, ${ }^{117}$ which would require a formal constitutional amendment. ${ }^{118}$

Despite possible overlaps, its can thus be concluded that the constitutional practice of the organization can be clearly distinguished from the subsequent practice of the parties to its constituent instrument. While the former has an exclusively internal dimension as a source of law in the internal legal order of the organization, the latter has effects inside and outside the organization due to the dual nature of the constituent instruments as constitutional contracts. ${ }^{119}$ While the internal practice may

\footnotetext{
${ }^{113}$ See Elihu Lauterpacht, 'The Development of the Law of International Organization by the Decisions of International Tribunals’, (1976-IV) 152 Recueil des Cours 377-478, at 458.

${ }^{114}$ Ibid., at 459. As Judge Spender stated in his separate opinion in the Certain Expenses case: “[I]t is not possible to equate 'subsequent conduct' with the practice of an organ of the United Nations. Not only is such an organ not a party to the Charter but the inescapable reality is that both the General Assembly and the Security Council are but the mechanisms through which the Members of the United Nations express their views and act. The fact that they act through such an organ, where a majority rule prevails and so determines the practice, cannot, it seems to me, give any greater probative value to the practice established within that organ than it would have as conduct of the Members that comprise the majority if pursued outside that organ.” Certain Expenses of the United Nations, Advisory Opinion of 20 July 1962, [1962] ICJ Rep. 151, at 192.

${ }^{115}$ See also Elihu Lauterpacht, 'The Development of the Law of International Organization by the Decisions of International Tribunals', (1976-IV) 152 Recueil des Cours 377-478, at 416, on the possibility that constitutional and traditional interpretation overlap.

${ }^{116}$ Amerasinghe considers practice as a means of "purposeful agreed evolution" in case of gaps in the constitutional texts. C.F. Amerasinghe, Principles of the Institutional Law of International Organisations (Cambridge: CUP 2005), at 60.

${ }^{117}$ As Lauterpacht notes: "The intention of the parties - express or implied - is the law. Any considerations - of effectiveness or otherwise - which tend to transform the ascertainable into a factor of secondary importance are inimical to the true purpose of interpretation". Hersch Lauterpacht, 'Restrictive Interpretation and the Principle of Effectiveness in the Interpretation of Treaties', (1949) 26 BYIL 48-85, at 73; as confirmed by the ECJ with regard to the European Council, Commission and Parliament but under the restriction that such practice "cannot derogate from rules laid down in the treaty." See, for instance, the Case 68/86 United Kingdom v Council [1988] ECR. 855 (para. 24); Case 131/86 United Kingdom v. Council [1988] ECR 905 (para. 29).

${ }^{118}$ In light of continuous attempts to re-invent NATO as collective security organization, White argues that "NATO members ought to make a new contract instead of trying to layer incompatible constitutional interpretation upon what is a narrow contractual treaty.” Nigel White, The Law of International Organisations (Manchester: Manchester University Press 2005), at 19 .

${ }^{119}$ The Special Rapporteur on the Law of Treaties between International Organizations and States observed in his Third Report, Paul Reuter, UN Doc. A/CN.4/279 and Corr.1 (1974), at152 (para. 28): "This expression basically reserves the constitutional regime of each organization: it is this regime, and not the draft articles, which will determine the scope of the 'practice'. If, therefore, under this regime, the constitution of the organization is partly customary in origin and practice may in that connexion play a role going beyond that provided for in article 31, paragraph 3 (b) of the 1969 Convention, it is this regime which will be applicable. To adopt any other solution would be to give written conventional law precedence over
} 
therefore be subject to "comparative constitutional studies" as a result of cross-fertilization between different international organizations, ${ }^{120}$ the latter falls within the scope of the law of treaties.

\subsection{THE SPECIAL NATURE OF THE UN CHARTER?}

Eventually, the legal nature of the UN Charter must be addressed, for among all constituent instruments of international organizations, the UN Charter is often said to have a special constitutional status. ${ }^{121}$ As Schachter noted already in 1951: "The Charter is surely not to be construed as a lease of land or an insurance policy, it is a constitutional instrument whose broad phrases were designed to meet changing circumstances for an undefined future." ${ }^{\text {"22 }}$ Indeed, a considerable number of scholars have argued that the UN Charter has grown into the constitution of the international community of States ${ }^{123}$ or as a whole, ${ }^{124}$ for there cannot be a community, understood as a distinct legal entity, without a constitution providing for its own organs: "Legal personality requires the actual ability to perform legal acts." ${ }^{125}$ However, while suggesting that there is no necessity to distinguish the UN internal legal order from the international legal order, these arguments neglect or even contest the importance of the UN Charter's equally relevant contractual limitations.

The main argument speaking in favour of attributing the status of a world constitution to the UN Charter is the universality of its constitutionalist aspirations, which was already present at the San Francisco Conference, but also developed as a result of practice in light of the UN Charter's broad objectives and the corresponding functions of its organs. The UN General Assembly is not only the plenary organ of the organization, but due to universal UN membership it also reflects the international community of States. The General Assembly has further been a major driving force

unwritten law as a source of the law peculiar to each organization, prevent the progressive development of the law of each organization and give rise to an unacceptable infringement of the constitutional autonomy of each organization; this, in the final analysis, is the meaning of draft article 6." On the evolution of the ILC's position on "subsequent practice of and in international organizations see also Shabtai Rosenne, 'Is the Constitution of an International Organization an International Treaty’, (1966) 12 Communicazioni e Studi 21-89, at 48.

${ }^{120}$ The use of "comparative constitutional studies” is suggested by Pierre Klein, 'International Organizations and Institutions - Internal Law and Rules', (2006) MEPIL, at para. 4. Among others, Lauterpacht notices a "cross-fertilization of constitutions" as recognized by different tribunals, see Elihu Lauterpacht, "The Development of the Law of International Organization by the Decisions of International Tribunals', (1976-IV) 152 Recueil des Cours 377-478, at 396.

${ }^{121}$ As discussed below, both the Articles on States Responsibility and the draft Articles on the Responsibility of International Organizations provide for reservations with regards to the UN Charter in Articles 59 and 66, respectively.

${ }^{122}$ Oscar Schachter, 'Review of Kelsen: The Law of the United Nations', (1951) 61 Yale Law Journal 189-193, at 193.

${ }^{123}$ See, for instance, Bruno Simma , 'From Bilateralism to Community Interest in International Law', (1994-VI) Recueil des Cours 221-384, at 262, stating: "I have no problems at all with viewing the basic norms of the Charter as the constitutional law of the universal international community, and the Charter organs, at least in practical terms, as organs of the international community of States as a whole.” For a similar position developed in an earlier work, see Alfred Verdross and Bruno Simma, Universelles Völkerrecht: Theorie und Praxis (Berlin: Duncker \& Humblot 1976), 71-83.

${ }^{124}$ See in particular Bardo Fassbender, 'The United Nations Charter as a Constitution of the International Community', (1998) 36 Columbia Journal of Transnational Law 529-619; Christian Tomuschat, International Law: Ensuring the Survival of Mankind on the Eve of a New Century, General Course on Public International Law, in 281 Recueil des Cours 10, 25. See also Pierre-Marie Dupuy, 'The Constitutional Dimension of the Charter of the United Nations Revisited', (1997) 1 Max Planck Yearbook of United Nations Law 1-34, illustraring that many authors agree with Tomuschat's claim that the UN Charter could be considered as a constitution of the international community even outside the German scholarly debate on the topic.

${ }^{125}$ Bardo Fassbender, 'The United Nations Charter as a Constitution of the International Community', (1998) 36 Columbia Journal of Transnational Law 529-619, at 566. 
behind the evolution of the UN towards a "universal multi-purpose organization", ${ }^{126}$ covering issues not originally or explicitly envisaged in the UN Charter. After the end of its Cold War palsy, the UN Security Council joined in this development by progressively interpreting its mandate to maintain international peace and security. In this context, it is particularly relevant that the entry into force of the UN Charter limited the use of force to a number of exceptions: self-defence under Article 51 and the collective action under Chapter VII by Security Council mandate. The use of force, as a traditional means of law enforcement by the State at the national and international level, was thus embedded in the institutional framework of the United Nations; ${ }^{127}$ in other words, the subjective decision to use force was objectivised in the UN's primary goal to "maintain international peace and security", ${ }^{128}$ and centralized with the UN Security Council.

In addition to the UN political organs, the International Court of Justice has made use of its dual role to reinforce the links between the international legal order and the internal UN system. On the one hand, the ICJ functions as the highest judicial organ in the United Nations, which has continuously strengthened the internal autonomy of the United Nations system, mainly in its advisory opinions. ${ }^{129}$ On the other hand, the jurisdiction of the ICJ is not limited to matters "specially provided for in the Charter of the United Nations”, but extends to all cases concerning international law referred to it by the parties, and even non-parties, to its Statute. ${ }^{130}$ The ICJ thus certainly has a special position in relation to other international judicial institutions, which makes it difficult to distinguish the two roles that the Court may play. The preliminary objections in the Nicaragua case, for instance, concerned the competing jurisdictions of the General Assembly and the Security Council, ${ }^{131}$ which was also an issue in the Wall Advisory Opinion. ${ }^{132}$

Nonetheless, the practice of the main UN organs, and its various subsidiaries, equally illustrates that the UN is limited by the principle of speciality - in other words, constitutional

\footnotetext{
${ }^{126}$ James Crawford, 'Multilateral Rights and Obligations', (2006-II) 319 Recueil des Cours 325-482, at 381.

${ }^{127}$ See Henry G. Schermers and Niels M. Blokker, International Institutional Law: Unity within Diversity (Boston: Martinus Nijhoff Publishers 2003), stating at 943 (para. 1493): "Thus, two inroads were made upon one of the core aspects of state sovereignty, the state's monopoly of the use of force. Decisions would be taken elsewhere to use "their" forces, for purposes to which the supplying member might not subscribe. Secondly, military enforcement measures might be taken by a supranational body against the wishes of most member states."

${ }^{128}$ See Article 1 para. 1 of the UN Charter.

${ }^{129}$ In its Effects of Awards Advisory Opinion, for instance, the Court stated that "the contention that the General Assembly is inherently incapable of creating a tribunal competent to make decisions binding on itself cannot be accepted. It cannot be justified by analogy to national laws, for it is common practice in national legislatures to create courts with the capacity to render decisions legally binding on the legislatures which brought them into being. The question cannot be determined on the basis of the description of the relationship between the General Assembly and the Tribunal, that is, by considering whether the Tribunal is to be regarded as a subsidiary, a subordinate, or a secondary organ, or on the basis that it was established by the General Assembly. It depends on the intention of the General Assembly in establishing the Tribunal, and on the nature of the functions conferred on it by its Statute. An examination of the language of the Statute of the Administrative Tribunal has shown that the General Assembly intended to establish a judicial body; moreover, it had the legal capacity under the Charter to do so." Effect of Awards of Compensation Made by the United Nations Administrative Tribunal, Advisory Opinion of 13 July 1954, [1954] ICJ Rep. 47, at 61.

${ }^{130}$ See Articles 35 and 36 of the ICJ Statute, 59 Stat. 1055, 33 UNTS 993 (1945).

${ }^{131}$ Military and Paramilitary Activities in and against Nicaragua case (Nicaragua v. United States of America), Judgment of 26 Nov. 1984, [1984] ICJ Rep. 392, at 43ff. (para. 89ff).

${ }^{132}$ Legal Consequences of the Construction of a Wall in the Occupied Palestinian Territory, Advisory Opinion of 9 Jul. 2004, [2004] ICJ Rep. 136, at 149, para. 27.
} 
constraints - in the same way as the constituent instruments of other international organizations. Due to a restricted conferral of competences by the contracting parties to the UN Charter, it has been one of the main challenges to constitutionalists that many UN mechanisms still require the individual consent of member States in order for the UN to effectively fulfil its functions. The jurisdiction of the ICJ is thus dependent on the consent of the parties to a dispute. Moreover, consent figures prominently in its contentious cases but also in several advisory opinions, in which the Court applies a mixture of constitutional and treaty interpretation to delineate the competences between the UN and its member States. ${ }^{133}$

Consent further presents an impediment towards constitutionalization of the international legal order in the form of the pacta tertiis rule, for the UN Charter only has legal effects on member States and cannot yield legal effects on third parties. ${ }^{134}$ Article 2 (6) of the UN Charter merely states that the Organization "shall ensure that states which are not Members of the United Nations act in accordance with these principles" of the Organization. Of course, the practice of the organization may still indirectly affect third parties, whether States or other entities, in terms of international customary law formation. The General Assembly is not only the plenary organ of the organization but is also composed of virtually all States in the international community. By voting for a General Assembly resolution, member States thus give expression to the corporate will of the United Nations, while also acting as States under general international law, which may be opposable to third parties under certain conditions, in particular in the form of custom. ${ }^{135}$

In the context of Security Council actions, Article 103 of the UN Charter, which is considered by some as a loyalty-creating obligation, ${ }^{136}$ deserves special mention. By obliging UN Members to give priority to their obligations under the Charter in case of conflict with their other inter-subjective

\footnotetext{
${ }^{133}$ See Shabtai Rosenne' Is the Constitution of an International Organization an International Treaty', (1966) 12 Communicazioni e Studi 21-89, at 35, stating with reference to the case law of the ICJ: "But this same polarization has invaded the strictly legal sphere - the International Court of Justice - and a succession of major, even spasmodic, judicial pronouncements concerning the interpretation and application of constituent instruments leaves little doubt that adherence to 'traditional' concepts of the law of treaties is not a prominent feature of the process of interpretation of the instruments by the Court, even though it is not displaced entirely."

${ }^{134}$ See Bardo Fassbender, 'The United Nations Charter as a Constitution of the International Community', (1998) 36 Columbia Journal of Transnational Law 529-619, at 581-584, arguing on the basis of the principle of sovereign equality that an exception to the pacta tertiis rule should be made with regard to the UN Charter. The pacta tertiis rule was originally only intended to apply to States in their mutual contractual relations. The question to which the rule can be applied to non-State entities other than international organizations is beyond the scope of this paper.

${ }^{135}$ General Assembly resolutions can be declaratory of customary norms or evidence of emerging custom by stating the necessary opinio iuris of governments in the widest forum for the expression of such opinions, dependent on their content and conditions of adoption: See Military and Paramilitary Activities in and against Nicaragua case (Nicaragua v. United States of America), Judgment of 27 Jun. 1986, [1986] ICJ Rep. 14, at 98-104 (para. 187-195) [hereinafter: Nicaragua case). On the effects on General Assembly resolutions see, for instance, Richard Falk, 'On the Quasi-Legislative Competence of the General Assembly’, (1966) 60 AJIL 782; Marko Divac Öberg, 'The Legal Effects of Resolutions of the UN Security Council and General Assembly in the Jurisprudence of the ICJ', (2006) 16 EJIL 879.

${ }^{136}$ See Karl Doering, 'Unlawful Resolutions of the Security Council and their Legal Consequences', (1997) 1 Max Planck Yearbook of United Nations Law 91-109, at 105, referring also to Articles 49 and 56 of the UN Charter and stating that it "is a general principle that members of a community are specifically obliged to render mutual assistance and support, and that is true for national and communities and international communities as well” against the background of the concept of "Bundestreue" developed by the German Constitutional Court with regard to the relationship between a federal State and its members (see BVerfGE Vol. 34, 216, at 232).
} 
international agreements, ${ }^{137}$ Article 103 allows the UN Charter to indirectly unfold effects vis-à-vis third parties. The ICJ confirmed in the Lockerbie case that Article 103 of UN Charter also applies to binding Security Council resolutions and has stated at other occasions that Security Council resolutions may give rise to "international legal obligations". ${ }^{138}$ However, the increasing resistance against the implementation of the UN counter-terrorism sanctions in the European Union and national legal orders may confirm the contractual limits of the constitutional effects of Article 103 of the UN Charter when confronted with other (and possibly) stronger public order regimes, which equally ask for loyalty from their member States. ${ }^{139}$ While the practice of the UN main organs has arguably contributed to a blurring of the lines between the internal UN legal order and the international legal system, the UN Charter shows the interplay between contractual and constitutional elements, as the constituent instruments of other international organizations.

\section{The "Rules of the Organization" in the Law of International Responsibility}

While the various constitutions of international organizations originate in different contractual arrangements, the resulting plurality of legal orders cannot be accommodated in a general or common set of international rules without difficulty. ${ }^{140}$ The ILC did therefore eventually recognize that the treaty may fulfill various functions and differ in substantive content, ${ }^{141}$ recognizing that the law of treaties should not "encroach upon the internal law of international organizations". ${ }^{142}$ In particular the

\footnotetext{
${ }^{137}$ It is noteworthy that Article 103 of the UN Charter does not refer to customary international law but only limits UN members in their "party autonomy" when concluding other international agreements.

${ }^{138}$ The ICJ has repeatedly underlined the international legal nature of obligations imposed by the UN Security Council. Most recently, the Court stated in its Kosovo Advisory Opinion that "Resolution 1244 (1999) was expressly adopted by the Security Council on the basis of Chapter VII of the United Nations Charter, and therefore clearly imposes international legal obligations." Accordance with International Law of Unilateral Declaration of Independence in Respect of Kosovo, Advisory Opinion of 22 July 2010, [ICJ] Rep., para. 86.

${ }^{139}$ See, for instance, the general provision of Article 4 (3), but also Articles 24 (3), 32, 34 and 35 of the Treaty on European Union (TEU), and the discussion on UN sanctions regimes in section 2.1.2 on "Applicability 'Without Prejudice to the UN Charter"” of this paper. The limits of Security Council actions have also been raised in other contexts, in particular with regard to humanitarian interventions. As Hans Kelsen once concluded, "the purpose of the enforcement action under Article 39 is not to maintain or restore the law, but to maintain or restore peace which is not necessarily identical with the law". Hans Kelsen, The Law of the United Nations. A Critical Analysis of Its Fundamental Problems (Clark: The Lawbook Exchange 2008), at 294. Reismann adds that the Security Council was not established as a "general law enforcer, it is a political organ and thus rather an "enforcer in extremis". Michael Reisman, 'Sanctions and Enforcement', in Cyrill Black and Richard Falk (eds.), The Future of the International Legal Order Vol. III (Princeton: Princeton University Press 1971), 273-355, at 311.

${ }^{140}$ As Focsaneanu observes: "Par ailleurs le droit interne des organisations internationales, tout comme le droit national, est composé d'une multitude de systèmes juridiques particuliers, chaque organisation internationale ayant, comme chaque Etat, son propre système juridique.” Lazar Focsaneanu, 'Le droit interne de l’Organisation des Nations Unies', (1957) 3 Annuaire français de droit international 315-349, at 326. See also Riccardo Monaco, 'Le caractère constitutionnel des actes institutifs d'organisations internationales', in Mélanges offerts à Charles Rousseau: La Communauté Internationale (Paris: Editions A. Pédone 1974), 153-172, at 162, stating at 162: "Par ailleurs, parmi les similitudes que présente l'acte institutif d'une Organisation internationale par rapport à une constitution étatique, il en est une qui mérite d'être particulièrement soulignée: ledit acte ne se présente pas seulement comme l'ensemble des norms fondamentales qui régissent un ordre juridique, mais il est lui-même un système juridique in nuce, puisqu'il constitue la base sur laquelle s'érigera graduellement l'ordre juridique de l’Organisation.” [emphasis added]

${ }^{141}$ This development began with the First Report on the Law of Treaties by the Special Rapporteur, Sir Humphrey Waldock, UN Doc. A/CN.4/144 and Add.1 (1962).

142 ILC Report, Fifteenth Session, UN Doc. A/CN.4/163 (1963), at 213. For a discussion of the various functions of treaties see Arnold D. McNair, 'The Functions and Differing Legal Character of Treaties', (1930) 11 BYIL 100-118, calling the treaty the "only and sadly overworked instrument with which international society is equipped for the purpose of carrying out its
} 
modalities for withdrawal from an organization, and termination and suspension of membership were seen as special characteristics of the constituent instruments of international organizations as opposed to other international agreements. ${ }^{143}$ Although Articles 5 of the 1969 and 1986 Vienna Conventions on the Law of Treaties emphasize that the law of treaties is applicable to the constituent instruments of international organizations, they therefore equally allow for a far-reaching general reservation by stating that this applicability is "without prejudice to any relevant rules of the organization". ${ }^{144}$

While the ILC apparently considered the rules of the organization as internal law of the organization in its work on the law of treaties, it decided not to take a clear-cut position on the legal nature of the rules of the organization as either internal law or international law in its work on the responsibility of international organizations. Whereas certain provisions of the DARIO such as those on attribution of conduct or reparation suggest that the rules of the organization have an internal legal character, ${ }^{145}$ other provisions such as those on the breach of an international obligation or countermeasures by a member State against an international organization give the opposite impression. ${ }^{146}$ As the ILC Commentary to Article 2 (b) of the DARIO explains, the rules of the organization do not only include the constituent instruments, decisions and resolutions and practice of the organization, but that the term "in particular" was retained from the definition taken from the 1986 Vienna Convention "since the rules of the organization may also include agreements concluded by the organization with third parties and judicial or arbitral decisions binding the organization.”147

On the basis of the analysis undertaken in Part 1, it is submitted in this paper that the ILC's decision not to take a clear-cut view of the nature of the rules of the organization results from a lack of distinction between the internal constitutional law of the organization and the contractual law that has given rise to the organization, and that is generally referred to as lex specialis for the purposes of international responsibility. Part 2 will therefore first clarify the scope of application of the general rules of international responsibility with regard to special rules of international law in force between

multifarious transactions”; and Catherine Brölmann, 'Law-Making Treaties: Form and Function in International Law', (2005) 74 Nordic Journal of International Law 383-404. On these constitutional characteristics, which distinguish the constituent instruments of international organizations from other treaties, see Shabtai Rosenne, 'Is the Constitution of an International Organization an International Treaty’, (1966) 12 Communicazioni e Studi 21-89, at 55; Henry G. Schermers and Niels M. Blokker, International Institutional Law: Unity within Diversity (Boston: Martinus Nijhoff Publishers 2003), at $724 f f$. (para. 1147ff).

${ }^{143}$ Ibid.

${ }^{144}$ This reservation equally applies to "any treaty adopted within an international organization”, which is made is accordance with the rules of the organization on treaty making. Nonetheless, Article 5 of the 1969 Vienna Convention is not unambiguous. As Brölmann characterizes the combination of the applicability of the 1969 Vienna Convention and simultaneous reservation: "This is a matter of the glass being half full or half empty." Catherine Brölmann, The Institutional Veil in Public International Law: International Organisations and the Law of Treaties (Oxford: Hart Publishing 2007), at 114. A more specific reservation is included in Article 20 (Acceptance of and objection to reservations): "[...] 3. When a treaty is a constituent instrument of an international organization and unless it otherwise provides, a reservation requires the acceptance of the competent organ of that organization." As one commentator notes with regard to this provision, "[l]a bilatéralisation des relations conventionnelles entre les Etats parties à un traité [...] ne peut clairement pas être étendue aux relations entre les Etats membres d'une organisation internationale qui doivent, dans le cadre juridique et institutionnel du sujet juridique dérivé créé, travailler ensemble afin de réaliser l'objet et le but du traité.” Daniel Müller, 'Article 20 Convention de 1969', in Oliver Corten and Pierre Klein (eds.), Les Conventions de Vienne sur le Droit des Traités: Commentaire article par article, Vol. I (Bruxelles: Bruylant 2006), 797-875, at 854.

145 See Articles 5, 31 (1) and 39 of the DARIO.

${ }^{146}$ See Articles 9 (2), 31 (2) and Article 51 of the DARIO.

${ }^{147}$ ILC Report, Sixty-first Session, UN Doc. A/64/10 (2009), at 50 (para. 15). 
the States that are members of an international organization (2.1). In light of the dual nature of the constituent instruments, it will be argued that the rules of the organization are internal constitutional law for member States and the organization, as long as the organization functions effectively. Only if an organization fails to function effectively, due to a diminishment of its factual autonomy, will its member States resort to the general rules of international responsibility in their capacity as States. In analyzing the conditions for wrongful conduct (2.2), as well as its legal consequences (2.3), it is thus suggested to either acknowledge in the ILC Commentary that the rules of the organization have an the internal constitutional nature or to replace the term "rules of the organization" by the more appropriate expression "internal law of the organization", which is equally preferred in legal doctrine. ${ }^{148}$ This new terminology - either in the text of the DARIO or in its Commentary - would also be very instrumental in introducing a methodological clarification: For the constituent instruments, legal acts and practice of the organizations are not "rules of the organization", as currently implied in the ILC's definition; they rather constitute a source of these rules or, conversely, be an emanation thereof in the internal legal order of the organization.

\subsection{THE SCOPE OF APPLICATION OF THE GENERAL RULES}

According to Article 1 of the DARIO, the draft Articles apply to the international responsibility of an international organization for an act that is wrongful under international law, but also to the international responsibility of a State for the internationally wrongful act of an international organization. While the DARIO thus have a broad scope of application, they also allow for one important qualification. As Article 63 states, the DARIO do not apply where and to the extent that the conditions and the content of international responsibility "are governed by special rules of international law". Although Article 63 of the DARIO thereby largely replicates Article 55 of the ASR, it adds that this lex specialis includes the "rules of the organization applicable to relations between the international organization and its members".

By taking into account the dual nature of the constituent instruments, it is suggested that this inclusion of the internal relations between an international organization and its member States is inconsistent with the origin and function of the lex specialis derogat lex generalis principle (2.1.1). The principle of lex specialis, as applied in the law of responsibility, only relates to the horizontal relations between autonomous subjects of international law that contract out of the general rules on international responsibility, for instance, by creating an international organization that has law enforcement competences internally. In contrast, the resulting relationship between an international organization and its member States has a vertical constitutional nature: it is internal law of the legal order of the respective organization. Suggesting otherwise may unduly limit the scope of application of both the law of responsibility of States and international organizations, as it may convey the false impression that member States and international organizations could avoid compliance with their

\footnotetext{
${ }^{148}$ The obvious drawback would be that the term "rules of the organization” has so far been consistently used by the ILC, albeit with varying meanings.
} 
international obligations towards third parties by means of special internal "rules of the organization", as illustrated by the example of the UN Charter (2.1.2).

\subsubsection{Lex Specialis}

Originally only applied as a means of statutory interpretation in domestic law, the principle of lex specialis has gained increasing popularity as a means for States to "contract out" of a given general regime of international law on the basis of their sovereign autonomy. ${ }^{149}$ The ILC has acknowledged this possibility of contracting out at several occasions, first in the already mentioned Article 5 of the 1969 Vienna Convention on the Law of Treaties, ${ }^{150}$ and lastly in Article 55 of the ASR and Article 63 of the DARIO. As the ILC Commentary to Article 55 of the ASR explains, the general rules may be displaced to the extent that special rules exist - subject to certain limitations. ${ }^{151}$ First of all, the lex specialis-lex generalis principle can only apply when both the special and the general rule deal with the same subject matter. The reservation in Article 55 of the ASR, for instance, covers special rules on the conditions for the existence of an internationally wrongful act and the content or implementation of the international responsibility of a State. ${ }^{152}$ In addition, the special rule must be actually inconsistent with the general rule, or show at least "a discernible intention that one provision is to exclude the other." ${ }^{, 153}$ While the applicability of general international law is not completely excluded, the extent to which the general rules of international law are displaced ultimately depends on the special rules in question. ${ }^{154}$ Accordingly, derogation from general international law is a partial matter or a matter of "extent". Article 55 of the ASR applies to "weak forms" of lex specialis that displace the general regime on a certain point, and "strong forms" of lex specialis that derogate from the general rules on State responsibility altogether.

While strong lex specialis is usually associated with international organizations such as the EU or World Trade Organization (WTO), it is submitted that the contractual term lex specialis is misleading if applied to international organizations that form autonomous legal orders. Indeed, the terms self-contained or sectoral regimes are regularly preferred to express the fact that international organizations such as the EU or WTO form their own partial constitutional orders, which are separate

\footnotetext{
${ }^{149}$ On the origins and different uses of the principle in international law Bruno Simma and Dirk Pulkowski, 'Of Planets and the Universe: Self-contained Regimes in International Law’, (2006) 17 EJIL 483-529, at 486ff. As Jenks observed already in 1953, "the conflict of law-making treaties [...] must be accepted as being in certain circumstances an inevitable incident of growth" of international law, and proposed several conflict solving principles, one of the being the lex specialis principle. C Wilfred Jenks, 'The Conflict of Law-making Treaties', (1953) 30 BYIL 401-453, at 405.

${ }^{150}$ As observed by Dallier with regard to Article 5 of the 1969 VCLT: “Or, on l'a dit, la justification essentielle de cette dérogation éventuelle réside dans le souci de ne pas faire obstacle à la dynamique des ordres juridiques secrétés par les organisations internationales, grâce à une solidarité plus forte entre leurs Etats membres que dans les relations internationales générales. Il convient cependant évident que, du fait des spécificités du droit de l’organisation, les droits des Etats non membres ou non parties puissent être compromis.” Patrick Dallier, ‘Article 5 - Convention de 1969', in Oliver Corten and Pierre Klein (eds.), Les Conventions de Vienne sur le Droit des Traités : Commentaire article par article, Vol. I (Bruxelles: Bruylant 2006), 137-157, at 145.

${ }^{151}$ ILC Yearbook 2001, vol. II (Part Two), at 140 (para. 4). See also Fitzmaurice, 'The Law and Procedure of the International Court of Justice 1951-54: Treaty Interpretation and Other Treaty Points’, (1957) 33 BYIL 203, at 237.

152 See also ILC Yearbook 2001, vol. II (Part Two), at 141 (para. 6).

153 ILC Yearbook 2001, vol. II (Part Two), at 140 (para. 4).

${ }^{154}$ ILC Yearbook 2001, vol. II (Part Two), at 140 (para. 3).
} 
from international law. ${ }^{155}$ By becoming members of an international organization, States have given up their facultés under general international law, for the benefit of special procedures to which they have a particular commitment. ${ }^{156}$ As long as these special procedures function effectively, the constituent instruments will define the relationship between the members of the organization and with the organization in constitutional terms, which may not exclude the consideration of general international law but only as conditioned by the legal order of the organization. ${ }^{157}$ The division of competences between an international organization and its members is therefore better characterized by the principle of speciality, than by that of lex specialis. ${ }^{158}$ The relevance of seeing the constituent instruments as contractual lex specialis only arises when the organization fails to function effectively, so that its member States may resort to the general law of State responsibility. They will do so in their capacity as States under international law in their horizontal relations inter se, and not in relation to the international organization. ${ }^{159}$ Accordingly, the internal law of an international organization thus cannot be equated with lex specialis in international law.

While the ILC did not necessarily have to distinguish between lex specials and internal law of international organizations when only focusing on States, the Commission could not avoid making this distinction in its work on the Articles on the Representation of States in their Relations with International Organizations. ${ }^{160}$ When the ILC Special Rapporteur El-Erian on the Representation of States presented his draft Article 4 on the "Relationship with the particular rules of international organizations”, other ILC members underlined the aspiration of the Commission to lay down general rules and rejected "the need for a general reservation to the effect that all the rules in the draft were

\footnotetext{
${ }^{155}$ See the Final Report of the ILC Study Group on Fragmentation of International Law, finalized by Martti Koskenniemi, UN Doc. A/CN.4/L.682 (2006), at 66 (para. 124), noting the ambiguity in the ILC's distinction between weak and strong forms of lex specialis when discussing self-contained regimes. See also Bruno Simma and Dirk Pulkowski, 'Of Planets and the Universe: Self-contained Regimes in International Law', (2006) 17 EJIL 483-529, making the convincing argument that other so-called self-contained regimes, such as human rights or the law of diplomatic relations, do not qualify as being selfcontained due to a lack of special inter-State enforcement procedures, so that the general law of international responsibility will always be applicable. For a different view see Evelyne Lagrange, La représentation institutionnelle dans l'ordre international. Une contribution à la théorie de la personnalité morale des organisations internationales (The Hague: Kluwer 2002), at 46, who apparently distinguishes the partial legal orders of international organizations from selfcontained regimes. However, the author's view is based on a broad understanding of self-contained regimes, including diplomatic law. Accordingly, even this author has to admit that "il suffit que la vie institutionnelle de l'organisation soit régie par des règles qui lui sont propres, excluant l'intervention d’un hypothétique droit général.”

${ }^{156}$ See the Statement by Mr. Arangio-Ruiz, ILC Yearbook 1992, vol I, Summary records of the $44^{\text {th }}$ session, 4 May 24 July, at 76.

${ }^{157}$ The WTO, for instance, relies on the general rules of treaty interpretation. As the Appellate Body observed, "the General Agreement is not to be read in clinical isolation from public international law", see US-Standards for Reformulated and Conventional Gasoline, WT/DS2/AB/R (1996), at 17.

${ }^{158}$ See this respect the joint comments by different international organizations on the DARIO on first reading in UN Doc. A/CN.4/637 (2011), at 39.

${ }^{159}$ See the discussion on countermeasures below. See also Vera Gowlland-Debbas, 'Responsibility and the United Nations Charter', in James Crawford et al., The Law of International Responsibility (Oxford: OUP 2010) 115-138, at 121, stating that "[i]t is a well established fact that parties to a treaty can derogate or contract out from the customary law rules at least in their relations inter se, and so long as that derogation is express and does not run counter to a peremptory norm of international law." [Original emphasis]

${ }^{160}$ See the draft Articles on the Representation of States in their Relations with International Organizations, with commentaries, ILC Yearbook 1971, vol. II (Part One), at 284-338.
} 
subject to the particular rules of organizations". ${ }^{161}$ This concern is echoed in later comments by international organizations, questioning whether their particular rules would take precedence over the general rules elaborated by the ILC and later codified in the Convention. ${ }^{162}$ Answering in the negative, Roberto Ago stated that he found it highly problematic that the ILC considered subjecting the draft Articles of the Representation of States to "particular rules which may be in force in the organization concerned”. ${ }^{163}$ As Ago rightly noted, "[a] special rule could not prevail over a general rule unless the two rules had the same status." ${ }^{164}$ In other words, the rules on the representation of States in a particular organization could not prevail over general international law because they do not have the same legal nature.

In line with the traditional horizontal focus of the ILC, Special Rapporteur El-Erian subsequently qualified that his reference to "particular rules" in draft Article 4 was intended to mean "the rules governing the external relations of the organization, that was to say its relations with States [which] might well not be members of the organization concerned". ${ }^{165}$ Consequently, in its final draft Articles on the Representation of States, the ILC decided to make an explicit distinction between the internal and external sphere of the organization, which was later endorsed in the 1975 Vienna Convention. Article 4 pertains to the "Relationship between the present articles and the relevant rules of the organizations", whereas Article 5 concerns the "Relationship between the present articles and other international agreements". Although the ILC maintained the ambiguous term "rules of the organization”, as included in the 1969 Vienna Convention, it made a clear distinction between lex specialis and internal law of the organization: While Article 4 thus acknowledges the possibility of lex specialis in force between an international organization and other subjects of international law horizontally, the ILC Commentary explains that Article 3 is meant to take account of the diversity in the internal rules of international organizations in their vertical dimension. ${ }^{166}$

\footnotetext{
${ }^{161}$ Statement by Mr. Ushakov, ILC Yearbook 1968, vol I, Summary records of the $20^{\text {th }}$ session, 27 May -2 Aug. 1968, at 28 (para. 27).

${ }^{162}$ As the ILO pointed out "the full significance of article 3 does not seem to it very clear. It expresses the fear that, judging strictly from the text of the article and the explanation given by the Commission in the commentary, it would appear that the Organization, in its relations with the host State and with a sending State, could completely ignore the provisions of the convention, even if the latter had been ratified by the two States: it could contend that its relevant rules and practices were different from those set forth in the convention and that consequently only the former were applicable. The ILO suggests that as that is surely not the intent of this provision, it would presumably be desirable to clarify somewhat the relationship between existing rules and practices and the draft convention.” Sixth Report of the Special Rapporteur on Relations between States and International Organizations, Mr. Abdullah El-Erian, UN Doc. A/CN.4/241 (1971), at 25 (para. 99).

${ }^{163}$ Statement by Mr. Ago, ILC Yearbook 1968, vol I, Summary records of the $20^{\text {th }}$ session, 27 May -2 Aug. 1968, at 31 (para. 24).

${ }^{164}$ Ibid.

${ }^{165}$ Statement by Mr. El-Erian, ILC Yearbook 1968, vol I, Summary records of the $20^{\text {th }}$ session, 27 May -2 Aug. 1968 , at 31 (para. 32). In 1968 the ILC therefore adopted, in addition to draft Article 3 (Relationship between the present articles and the relevant rules of international organizations), draft Article 4 (Relationship between the present articles and other existing international agreements) and draft Article 5 (Derogation from the present articles). The joint ILC Commentary to draft Articles 4 and 5 recognized that some ILC members considered the two draft Articles unnecessary since the term "rules of the organization" could be interpreted to cover international agreements relating to representatives of States to international organizations. However, the majority of the members considered it more appropriate to devote two separate Articles to the diversity of agreements relating to international organizations; see ILC Yearbook 1968, vol. II, at 198 (para. 1).

${ }^{166}$ See ILC Commentary to the draft Articles on the Representation of States, ILC Yearbook 1971, vol. II (Part One), at 287288.
} 
Against the background of the ILC's previous work on States and international organizations, it is therefore suggested that the DARIO should clearly distinguish between the internal constitutional rules of the organization and the international contractual rules in force between its member States in their capacity as parties to the constituent instruments. The law in force between an international organization and its member States is internal law of the organization, and not international lex specialis. Accordingly, the reference to the "rules of the organization applicable to the relations between the international organization and its members" as lex specialis should be eliminated from Article 63 of the DARIO. Only then will the reference to the special rules of international law in Article 63 correspond to the traditional nature and function of lex specialis, as reflected in Article 55 of the ASR.

In its current form Article 63 is not only conceptually misleading, but also brings about farreaching consequences in terms of the effectiveness of the system of responsibility. Indeed, if the ILC were to decide to keep Article 63 of the DARIO in its current wording, the Commission may give the wrong impression that States or international organizations could avoid compliance with their international obligations, which is a situation that the DARIO explicitly mean to prevent by virtue of other provisions. In fact, Article 16 provides that an international organization incurs international responsibility "if it adopts a decision binding a member State or international organization to commit an act that would be internationally wrongful if committed by the former organization and would circumvent an international obligation of the former organization.” In a similar vein, Article 60 of the DARIO stipulates that a State member of an international organization incurs international responsibility "if it seeks to avoid complying with one of its own international obligations by taking advantage of the fact that the organization has competence in relation to the subject matter of that obligation, thereby prompting the organization to commit an act”. 167

The necessity to include Articles 16 and 60 in the DARIO seemed to arise from the fact that the "rules of the organization" in force between the member States and an international organization may be international law according to the DARIO in their current version. ${ }^{168}$ For if the rules of the organization were characterized as internal law, it would be clear that neither States nor international organizations can use the internal acts of the organization, stemming from its competence to take

\footnotetext{
${ }^{167}$ Paragraph 2 of both Article 16 and 60 states that paragraph 1 applies whether or not the act in question is internationally wrongful for the member State (Article 16) or international organization (Article 60) that is used to circumvent or avoid compliance with international obligations.

${ }^{168}$ In this context, it is noteworthy that Articles 16 and 60 of the DARIO are far from uncontroversial. For a comparative discussion of both provisions see Pieter Jan Kuijper, 'Amsterdam Center for International Law: Introduction to the Symposium on Responsibility of International Organizations and of (Member) States: Attributed or Direct Responsibility or Both?', (2010) 7 IOLR 9-33, at 26-30. On Article 60 see in particular Jean d'Aspremont, 'Abuse of the Legal Personality of International Organizations and the Responsibility of Member States', (2007) 4 IOLR 91-119, at 99; and Esa Paasivirta, 'Responsibility of a Member state of an International Organization: Where Will It End? Comments on Article 60 of the ILC Draft on the Responsibility of International Organizations', (2010) 7 IOLR 49-61. On Article 16 see Niels Blokker, Abuse of the Members: Questions concerning Draft Article 16 of the Draft Articles on Responsibility of International Organizations', (2010) 7 IOLR 35-48. Article 16 is arguably more problematic than 60, for paragraph 2 of Article 16 allows for the possibility that that an international organization incurs responsibility as result of a recommendation if its member acts upon that recommendation. In commenting on the DARIO on first reading, ILO, for instance, therefore criticized that a mere recommendation would require an "intervening act" to result in international responsibility so that the "chain of causation would be thus broken.” UN Doc. A/CN.4/637 (2011), at. 29.
} 
decisions, to circumvent their international obligations. If the "rules of the organization" are characterized as internal law of the organization, it would also become clear that Articles 16 and 60 of the DARIO only reiterate the general scope of application of the law of international responsibility, provided for in Articles 1 and 3 of the ASR and the DARIO, respectively: Every internationally wrongful act of a State or an international organization entails the responsibility of that State or international organization. ${ }^{169}$ By recognizing that the rules of the organization are internal law, the added value of Articles 16 and 60 of the DARIO would thus be diminished.

\subsubsection{Applicability "Without Prejudice to the Charter of the United Nations"}

Besides the general reservation in Article 63, the DARIO allow for a special reservation to their scope of application with regard to the UN Charter. In replicating Article 59 of the ASR, Article 66 of the DARIO states: "These articles are without prejudice to the Charter of the United Nations.” Article 59 is generally understood as a saving clause, which recognizes the special role of the UN Charter as contractual lex specialis that established the United Nations. ${ }^{170} \mathrm{By}$ concluding the Charter, UN member States contracted out of the general regime of responsibility by means of a special agreement, providing for special rules on responsibility, ${ }^{171}$ and instruments for their implementation. ${ }^{172}$ The main UN institutions and their various subsidiaries have acted in their capacity as organs of the organization to implement the responsibility of parties to the UN Charter for violations of its provisions. Accordingly, the ICJ stated in its Namibia Advisory Opinion:

"It would have been an untenable interpretation to maintain that, once such a declaration has been made the Security Council under Article 24 of the Charter, on behalf of all member states, those members would be free to act in disregard of such illegality...A binding determination made by a competent organ of the United Nations to the effect that a situation is illegal cannot remain without consequence." ${ }^{\text {"173 }}$

\footnotetext{
${ }^{169}$ On this point Tzanakopoulas interestingly observes with regard to Article 16 of the DARIO that "it is accepted that the adoption of legislation by a State may amount to the breach of an international obligation, even if no action has been taken under the legislation in its implementation. Whether and to what extent a normative act will amount to a breach of an international obligation will depend on the content of the primary rule. Why this should be any different with respect to IOs, so as to require - in lieu of the normal operation of the rules for the engagement of responsibility - a special provision is not entirely clear.” Antonios Tzanakopoulos, Disobeying the Security Council. Countermeasures against Wrongful Sanctions (Oxford: OUP 2011), at 48. For a discussion of the "Breach of a Rule of the Organization" see section 2.2.2. of this paper.

${ }^{170}$ As Gowlland-Debbas explains, Article 59 thereby has to be distinguished from Article 55 of the ASR, which is a saving clause with regard to sub-systems at the same level as the ASR, while the UN Charter has a hierarchically higher status; see Vera Gowlland-Debbas, 'Responsibility and the United Nations Charter', in James Crawford et al., The Law of International Responsibility (Oxford: OUP 2010) 115-138, at 117. However, the precise scope of Article 59 of the ASR is not uncontroversial. Gowlland-Debbas therefore further notes at 122. "It is difficult to determine whether the formulation in article 59 is an improvement on the previous draft article 39 and to what extent it acts a safeguard to ensure that the rules on responsibility 'would not be subject as appropriate to derogation by arbitrary, ulta vires decisions of a political body'."

${ }^{171}$ It has, for instance, been suggested that the prohibition of the use of force prevents States from invoking the state of necessity as a circumstance precluding the wrongfulness of their use of force. See Sarah Heathcote, 'Est-ce que l'état de nécessité est est un principe de droit international coutumier?’, (2007) Revue belge de droit international 53-89, at 85.

172 On the special role of the UN Security Council in international law enforcement see Vera Gowlland-Debbas, 'Security Council Enforcement Action and Issues of State Responsibility', (1994) 43 ICLQ 55-98.

${ }^{173}$ Legal Consequences for States of the Continued Presence of South Africa in Namibia (South West Africa), Advisory Opinion of 20 June 1971, [1971] ICJ Rep. 16, at 52 (para. 112).
} 
To the extent that Article 66 of the DARIO covers this horizontal dimension of the UN Charter, as a contract between States it is therefore clearly redundant with regard to Article 59 of the ASR. ${ }^{174}$

Unlike States, however, international organizations are not contracting parties to the UN Charter. As the ILC Commentary to Article 66 of the DARIO rightly notes, a "question may be raised only with regard to the responsibility of international organizations, since they are not members of the United Nations and therefore have not formally agreed to be bound by the Charter." ${ }^{175}$ In order to remedy this lack of formal consent, the ILC seems to propose that international organizations are bound by the UN Charter in its constitutional dimension, which would - if one follows the ILC's proposition - subject them to the internal legal order of the United Nations. ${ }^{176}$ Indeed, Article 66 could be interpreted as establishing a hierarchy between the United Nations and other treaty regimes, including those that establish international organizations, on the basis of Article 103 of the UN Charter. As the ILC had already observed in its Commentary to Article 59 of the ASR, "the competent organs of the United Nations have often recommended or required that compensation be paid following conduct by a State characterized as a breach of its international obligations, and article 103 may have a role to play in such cases." ${ }^{\prime 77}$ The Commentary to Article 66 of the DARIO adds that such characterizations by the competent organs of the UN may also apply to the activities of international organizations. ${ }^{178}$

By including international organizations in the constitutional sphere of the United Nations, the ILC most likely intended to enhance the responsibility of international organizations, in the same way as UN activities have developed the law of State responsibility. ${ }^{179}$ However, by subjecting international organizations to the UN Charter, the DARIO suggest that third parties are bound by the constitutional contract of the United Nations without their consent. From this perspective, the UN Charter is not merely internal law of the United Nations but international law that obliges other subjects of international law to follow the acts of UN organs such as the Security Council in the sense of a "world constitution". This observation is supported by the decision of the European Court of First Instance (CFI) in the well-known Kadi case, ${ }^{180}$ but also by several decisions of the European Court of

\footnotetext{
${ }^{174}$ As the ILC Commentary to Article 66 of the DARIO acknowledges: "Insofar as this general provision relates to issues of State responsibility that are covered in the current draft, there could be no reason to query the applicability of the same 'without prejudice' provision as the corresponding article on the responsibility of States for internationally wrongful acts." ILC Report, Sixty-first Session, UN Doc. A/64/10 (2009), at 177 (para. 2).

175 ILC Report, Sixty-first Session, UN Doc. A/64/10 (2009), at 177 (para. 2).

176 The ILC Commentary to Article 66 explains that "even if the prevailing effect of obligations under the Charter may have a legal basis for international organizations that differs from the legal basis to States, practice points to the existence of a prevailing effect also with regard to international organizations.” ILC Report, Sixty-first Session, UN Doc. A/64/10 (2009), 178 (para. 2), citing Bardo Fassbender, 'The United Nations Charter as a Constitution of the International Community', (1998) 36 Columbia Journal of Transnational Law 529-619, at 609.

${ }^{177}$ ILC Yearbook 2001, vol. II (Part Two), at 143 (para. 1).

${ }^{178}$ ILC Report, Sixty-first Session, UN Doc. A/64/10 (2009), at 178.

${ }^{179}$ See generally Vera Gowlland-Debbas, 'Security Council Enforcement Action and Issues of State Responsibility', (1994) 43 ICLQ 55-98.

${ }^{180}$ Yassin Abdullah Kadi v Council of the European Union and Commission of the European Communities, Case T-315/01 (2005).
} 
Human Rights (ECtHR) following the line of its Behrami and Saramati judgment. ${ }^{181}$ The rejection of these courts to review Security Council resolutions could be interpreted as recognition of the primacy to the UN Charter over their respective internal legal orders. ${ }^{182}$ As a result, their member States could justify their non-compliance - or rather avoid compliance - with the obligations owed towards these organizations by reference to the UN Charter.

Nonetheless, considering that this deference to the UN Charter has left the breach of the internal rule of the respective other international organization without a remedy, the judgments of the CFI and in particular the European Court of Human Rights have received substantial criticism. ${ }^{183}$ While the ECtHR has so far not departed from its Behrami and Saramati doctrine, the European Court of Justice set aside the CFI's controversial judgment and emphasized that "an international agreement cannot affect the allocation of powers fixed by the Treaties or, consequently, the autonomy of the Community legal system”. ${ }^{184}$ It further emphasized that former Article 307 of the Treaty on the European Community, which is meant to leave earlier treaties concluded by members unaffected, "may in no circumstances permit any challenge to the principles that form part of the very foundations of the Community legal order, which include the principles of liberty, democracy and respect for human rights and fundamental freedoms enshrined in Article 6(1) EU as a foundation of the Union.”185 The ECJ therefore rejected the argument that the contested regulation had immunity from jurisdiction due to "the alleged absolute primacy of the resolutions of the Security Council to which that measure is designed to give effect”, ${ }^{186}$ and annulled the regulation in question.

In light of the ECJ's Kadi judgment, it could certainly be argued that the legal effects of Article 103 of the UN Charter are limited to the internal legal order of the United Nations and do not extend to the constitutional orders of other international organizations, which are not members of the

\footnotetext{
${ }^{181}$ Behrami v. France (application no. 71412/01) and Saramati v. France, Germany and Norway (no. 78166/01), European Court of Human Rights, Grand Chamber, 2 May 2007, and the subsequent judgment in Berić and others v. Bosnia and Herzegovina, European Court of Human Rights, Fourth Session, 16 October 2007.

${ }^{182}$ See, for instance, Kirsten Schmalenbach, 'Normentheorie vs. Terrorismus: Der Vorrang des UN-Rechts vor EU-Recht', (2006) 61 Juristenzeitung 349-353, at 352, speaking of “Unterordnung” (submission).

${ }^{183}$ For the mixed reactions to the Kadi judgment of the CFI see exemplarily Christina Eckes, 'Judicial Review of European Anti-Terrorism Measures - The Yusuf and Kadi Judgments of the Court of First Instance', (2008) 14 European Law Journal 74-92; Larissa van den Herik, The Security Council’s Targeted Sanctions Regimes: In Need of Better Protection of the Individual, (2007) 20 LJIL 797-807. The Behrami and Saramati case was mainly criticized for its modification of the "effective control" test in Article 6 of the DARIO (for a discussion of this test see section 2.2.1 on "Attribution of Conduct"), which led the attribution of the conduct of both States and NATO to the United Nations so that the ECtHR found the case inadmissible on the basis of a lack of jurisdiction ratione personae. Among the many critical voices see, for example, Philippe Lagrange, 'Responsabilité des Etats pour actes accomplis en application du Chapitre VII de la Charte des Nations Unies’, (2008) 112 Revue générale de droit international public 85-110; Pierre Klein, 'Responsabilité pour les faits commis dans le cadre d'opérations de paix et étendue du pouvoir de contrôle de la Cour européenne des droits de l'homme: quelques considérations critiques sur l'arrêt Behrami et Saramati', (2008) 53 Annuaire français de droit international 43-64; Francesco Messineo, 'The House of Lords in Al-Jedda and Public International Law: Attribution of Conduct to UN-Authorized Forces and the Power of the Security Council to Displace Human Rights', (2009) 56 Netherlands International Law Review 35-62.

${ }^{184}$ Yassin Abdullah Kadi and Al Barakaat International Foundation v Council of the European Union and Commission of the European Communities, Joined Cases C-402/05 P and C-415/05 P (2008), para. 282.

${ }^{185}$ Ibid., at para. 304. Article 307 TEC reads: 'The rights and obligations arising from agreements concluded before 1 January 1958 or, for acceding States, before the date of their accession, between one or more Member States on the one hand, and one or more third countries on the other, shall not be affected by the provisions of this Treaty.'

${ }^{186}$ Yassin Abdullah Kadi and Al Barakaat International Foundation v Council of the European Union and Commission of the European Communities, Joined Cases C-402/05 P and C-415/05 P (2008), para. 305.
} 
United Nations or part of the UN system. ${ }^{187}$ As long as the EU - or any other international organization - is not a member of the United Nations, UN member States may thus be faced with the dilemma of an unavoidable breach of either the UN Charter or the internal law of another international organization. ${ }^{188}$ In this sense, the UN Charter is not different from the constituent instruments of other international organizations. Although it gives rise to internal constitutional law for the member States of the United Nations, it is internal law of the UN - or res inter alios acta in contractual terms - for third parties such as other international organizations. In retaining Article 66 in the DARIO on second reading, the ILC should be aware of the far-reaching constitutional implications of this decision, and its restrictive effects on the DARIO's scope of application. It is not by chance that the ILC has to explain in its Commentary to Article 66 that the "present article is not intended to affect the applicability of the principles and rules set forth in the preceding articles to the international responsibility of the United Nations." ${ }^{\text {189 }}$ Considering that the UN Charter is the internal law of the United Nations, neither the UN nor its member States can invoke it to avoid compliance with their international obligations. Accordingly, Article 66 should be eliminated from the DARIO on second reading so as to provide the draft Articles with a clear scope of application regarding the conditions and content of international responsibility.

\subsection{CONDITIONS OF WRONGFUL CONDUCT}

While the recognition that the rules of an organization are internal law of that organization sheds light on DARIO's general scope of application, it also substantiates the applicability of the more specific draft Articles such as those on the conditions for the establishment of responsibility. The provisions on

\footnotetext{
${ }^{187}$ In a similar vein see Jean d'Aspremont and Fréderic Dopagne, 'Two Constitutionalisms in Europe: Pursuing an Articulation of the European and International Legal Order’, (2009) 69 Heidelberg Journal of International Law (ZaöRV) 939-978, discussing inter alia the "systemic limits of international constitutionalism". For a critical view of the ECJ's Kadi judgement see Grainne de Burca, 'The European Court of Justice and the International Legal Order After Kadi’ (2010) 51 Harvard International Law Journal 1-49, suggesting that the ECJ's approach could encourage other States and polities to assert the primacy of their respective order over the values and common goals of the international community. On this point see also André Nollkaemper, 'The European Courts and the Security Council: Between Dédoublement Fonctionnel and Balancing of Values: Three Replies to Pasquale De Sena and Maria Chiara Vitucci’, (2009) 20 EJIL 853-887, at 862-870.

${ }^{188}$ As the ILC concluded in its work on the law of treaties, contrary to a proposal by then Special Rapporteur Sir Hersch Lauterpacht, both of two conflicting treaties should be considered equally valid in such a case. Non-performance of either treaty obligation would merely give rise to a wrongful act triggering the international responsibility of the State. See Michael Reisman and Dirk Pulkowski, 'Nullity in International Law', (2006) MEPIL para. 6; see also the Report of the Special Rapporteur on the Law of Treaties, Sir Hersch Lauterpacht, UN Doc. A/CN.4/63 (1953). The idea that States cannot evade their responsibility for their obligations under other treaties is clearly expressed in the Waite and Kennedy case in which the European Court of Human Rights held: "The Court is of the opinion that where States establish international organisations in order to pursue or strengthen their cooperation in certain fields of activities, and where they attribute to these organisations certain competences and accord them immunities, there may be implications as to the protection of fundamental rights. It would be incompatible with the purpose and object of the Convention, however, if the Contracting States were thereby absolved from their responsibility under the convention in relation to the field of activity covered by such attribution”, Richard Waite and Terry Kennedy v. Germany, (application no. 26083/94), European Court of Human Rights, 18 Febr. 1999 , para. 67. As discussed in section 2.3.2 on "Countermeasures by Member States", States thus have an interest to harmonize their various obligations.

${ }^{189}$ ILC Report, Sixty-first Session, UN Doc. A/64/10 (2009), at 178 (para. 3). Despite this statement in the ILC Commentary, the UN conspicuously replied in its comments to Article 66 of the DARIO on first reading: "Unlike other organizations, however, which under Article 31 of the draft Articles may not rely on their rules as a justification for failure to comply with their international obligations, the United Nations could invoke the Charter and Security Council resolutions - to the extent that they reflect an international law obligation - to justify what might otherwise be regarded as non-compliance.” UN Doc. A/CN.4/637/Add.1 (2011), at 60 (para. 4). For a discussion of Article 31 of the DARIO see section 2.3 of this paper.
} 
the attribution of conduct in Article 5 of the DARIO and a breach of an international obligation by the international organization in Article 9 of the DARIO both refer to the "rules of the organization", without specifying whether these rules have an internal or international legal nature. In addition, the DARIO do not include a provision similar to Article 3 of the ASR, which reads:

"The characterization of an act of a State as internationally wrongful is governed by international law. Such a characterization is not affected by the characterization of the same act as lawful by internal law.”

While Article 3 has an important introductory function in the ASR by setting out the relationship between internal and international law in the characterization of an internationally wrongful act of the State, ${ }^{190}$ Special Rapporteur Gaja decided not to include a similar provision in the DARIO and thereby expressly rejected the term "internal law" by referring inter alia to the international nature of the constituent instruments. ${ }^{191}$

The ILC's references to contractual arguments can be useful in underlining that the autonomy of international organizations and their internal legal orders is limited by the continued role of its member States in their capacity as States under international law. Certainly, the contracting parties to the constituent instruments remain the "Masters of the Treaty" in the sense that they have the freedom to dissolve the organization by means of a collective act. However, considering the dual nature of the constituent instruments, these contractual references seem to be difficult to reconcile with the degree of constitutional autonomy required for international organisations to act autonomously for purposes of the law of responsibility. ${ }^{192}$ In fact, by declaring per definitionem in Article 2 (a) of the DARIO that international organizations have legal personality, the ILC implicitly recognizes that the constituent instruments of international organizations also have a constitutional nature by establishing a new legal actor, and a correlative legal order. ${ }^{193}$ The inclusion of a provision similar to Article 3 of the ASR

\footnotetext{
${ }^{190}$ ILC Yearbook 2001, vol. II (Part Two), at 36 (1).

${ }^{191}$ On the one hand, the Special Rapporteur justified this omission by the fact that the characterization of a given act as internationally wrongful independently from the internal law of the State concerned was a well-recognized principle, which could be affected by "other systems of law". On the other hand, he considered it problematic to apply the term "internal law" to organizations since at least the constituent instruments were part of international law. See the First Report of the Special Rapporteur on the Responsibility of International Organizations, Giorgio Gaja, UN Doc. A/CN.4/532 (2003), at 9-20 (para. 37).

${ }^{192}$ See Reparations for Injuries Suffered in the Service of the United Nations, Advisory Opinion of 11 Apr. 1949, [1949] ICJ Rep. 174, in which the ICJ found international legal personality was a precondition to bring a claim under the law of international responsibility. In its work on the accountability of international organizations, the International Law Association was much less hesitant to adopt the formulation of Article 3 of the ASR for its recommended rules and practices: "The characterization of an act of an international organization as internationally wrongful is governed by international law. Such characterization is not affected by the characterization of the same act as lawful by the international organization's internal legal order." ILA Committee on the Accountability of International Organisations, Report of the Seventy-First Conference, Berlin (2004), at 199. The ILC Commentary to the DARIO refers to this passage by stating that the ILA "appears to start from the assumption that the rules of the international organization in question are not part of international law." (ILC Report, Sixty-first Session, UN Doc. A/64/10 (2009), at 79 (FN139).

${ }^{193}$ The ILC Commentary to the DARIO even explicitly acknowledges the possibility of normative hierarchy between the rules of the organization: "The definition of the rules of the organization is not intended to imply that all the rules pertaining to a given international organization are placed at the same level. The rules of the organization concerned will provide, expressly or implicitly, for a hierarchy among the different kinds of rules. For instance, the acts adopted by an international organization will generally not be able to derogate from its constituent instruments.” ILC Report, Sixty-first Session, UN Doc. A/64/10 (2009), at 50 (para. 17).
} 
would only underpin the autonomy of an international organization from its constituent components during its life span. ${ }^{194}$

By considering the rules of the organization as "internal law of the organization", it is proposed that the autonomy of an international organization will allow it to exert constitutional or "normative" control over its constituent components, including its member States, within the limits of its competences. For the purpose of attribution of conduct, the member States of an international organization could under certain circumstances be qualified as (de facto) organs under the internal law of the organization, which are to be distinguished from situations of agency in which the organization only exercises effective control over the organs of a State (2.1.1). Within the functional remits of its constitution, an international organization thus has can take autonomous decisions that may result in a breach of its international obligations, due to the inconsistency of this internal act with the requirements of the respective international primary obligation (2.1.2). However, since States rarely ever confer all their sovereign powers in a given field to an international organization, they may be concurrently responsible with the international organization for breaching one of their own primary obligations by an act in their own internal legal orders.

\subsubsection{Attribution of Conduct}

The general rule on attribution of conduct in Article 5 of the DARIO provides that the conduct of an organ or agent shall be considered as "an act of that organization under international law whatever position the organ or agent holds in respect of the organization”. It thereby appears to replicate Article 4 of the ASR by analogy, with the necessary modifications. While the attribution of conduct is therefore ultimately a normative operation governed by international law, ${ }^{195}$ the role of internal law is not to be underestimated for attribution purposes. Like Article 4 of the ASR, paragraph 2 of Article 5 of the DARIO therefore recognizes that the rules of the organization may be decisive in the determination of the functions of its organs and agents. However, unlike Article 4 of the ASR, the reference to rules of the organization in Article 5 of the DARIO does not only have an internal constitutional dimension. As the ILC Commentary to Article 63 of the DARIO suggests, the rules in force between an international organization and its members could be special international law or lex specialis. ${ }^{196}$

One of the primary reasons for this qualification of the internal law of the organization as lex specialis seems to lie in the special situation of the European Union, which has repeatedly requested special rules on attribution of conduct for regional economic integration organizations. ${ }^{197}$ The ILC Commentary to Article 63 of the DARIO consequently refers to the possible existence of a special rule with regard to "attribution to the European Community of conduct of States members of the

\footnotetext{
${ }^{194}$ As Higgins explains: “An international association lacking legal personality and possessing no volonté distincte remains the creature of the states members who are thus liable for its acts". Rosalyn Higgins, 'The Legal Consequences for Member States of the Non-Fulfilment by International Organizations of their Obligations toward Third Parties', in (1995) 66-I Annuaire de l'Institut de Droit International, at 254.
} 
Community when they implement binding acts of the Community”. ${ }^{198}$ Several scholars have supported this approach by formulating such special rules of attribution. ${ }^{199}$ For instance, Hoffmeister most recently suggested the following provision:

"The conduct of a State that executes the law or acts under the normative control of a regional economic integration organization may be considered an act of that organization under international law, taking account of the nature of the organization's external competence and its international obligations in the field where the conduct occurred." 200

While this author considers that this provision is implicitly covered by Article 63 on lex specialis, he notes that the explicit acknowledgement of such a rule may give "important guidance" to international dispute settlement mechanisms, which has to deal with litigation against the European Union and/or its member States. $^{201}$

In light of the dual nature of the constituent instruments of international organizations discussed in the first part of this paper, it is argued that the rules on the allocation of competences between the EU and its member States are not international lex specialis but are solely part of its internal constitutional law. The observation applies to all other international organizations with separate legal personality. Indeed, the normative control exercised by an international organization is the consequence of the conferral of powers by the contracting parties to the constituent instruments, giving rise to the constitution of the international organization. As a result of this conferral of powers, member States disappear behind the corporate veil of the organization, and their relationship with the organization is defined by internal constitutional arrangements. ${ }^{202}$ To the extent that an international organization has competence, its member States and individuals such as staff members or other entities could be considered "organs" of the international organization for purposes of the attribution of conduct under Article 5 of the DARIO.

In comparison with other international organizations, the special situation of the European Union results not so much from the fact that it has normative control over its member States in certain areas, but rather from the degree of normative control that it exercises in its internal relationship with

\footnotetext{
195 ILC Yearbook 2001, vol. II (Part Two), at 35 (para. 6) and 39 (para. 4).

${ }^{196}$ ILC Report, Sixty-first Session, UN Doc. A/64/10 (2009), at 173 (para. 2).

${ }^{197}$ See for instance, the comments by the European Commission, in UN Doc. A/CN.4/545 (2004), at 18, and UN Doc. UN Doc. A/CN.4/637 (2011), at 7.

${ }^{198}$ ILC Report, Sixty-first Session, UN Doc. A/64/10 (2009), at 176 (para. 2).

${ }^{199}$ One of the first proposals was made by Stefan Talmon, 'Responsibility of International Organizations: Does the European Community Require Special Treatment?’, in Maurizio Ragazzi (ed.), International Responsibility Today: Essays in Memory of Oscar Schachter (Brill Publications, 2005) 405-421. See also Esa Paasivirta and Pieter Jan Kuijper, 'Does One Size Fit All?: The European Community and the Responsibility of International Organizations', in (2005) 36 Netherlands Yearbook of International Law 169-226, at 216, discussing specifically the role of the "rules of the organization" in the attribution of conduct to the EU and/or its member States.

${ }^{200}$ Frank Hoffmeister, 'Litigating against the European Union and Its Member States - Who Responds under the ILC’s Draft Articles on International Responsibility of International Organizations?', (2010) 21 EJIL 723-747, at 746. [emphasis added]

${ }^{201}$ See Frank Hoffmeister, 'Litigating against the European Union and Its Member States - Who Responds under the ILC’s Draft Articles on International Responsibility of International Organizations?’, (2010) 21 EJIL 723-747, at 746.

${ }^{202}$ Kelsen underlines that "in a wider sense of the term, any member of a community is its organ, meaning an individuals or body of individuals determined by the legal order, constituting the community, to execute or to create the norms of this order." Hans Kelsen, The Law of the United Nations. A Critical Analysis of its Fundamental Problems (London: Stevens and Son 1951), 149.
} 
its member States. Accordingly, all international organizations can be said to have normative control over their members to an extent depending on their competences. However, as previously noted, the EU is so far the only international organization with exclusive competence in certain subject-matters. As a result, it would only be consistent to consider its member States as organs of the European Union under those circumstances. This finding finds support in the EC Trademarks case in which a WTO panel

“accepted the European Communities' explanation of what amounts to its sui generis domestic constitutional arrangements that Community laws are generally not executed through authorities at Community level but rather through recourse to the authorities of its member States act as de facto as organs of the Community, for which the Community would be responsible under WTO law and international law in general.,203

In this context, it could be argued that Article 5 of the DARIO only appears to follow the text of Article 4 of the ASR. Its underlying rationale rather reflects that of Article 5 of the ASR on "conduct of persons or entities exercising elements of governmental authority”, which are commonly termed "de facto organs". ${ }^{204}$ Article 5 of the ASR specifically provides that the conduct of a person or entity, which is not a de jure organ of the State, may still be attributable to the State if the organ is empowered to exercise elements of governmental authority by the law of that State in the particular instance in question. The term "governmental authority" thereby refers to the "exercise of functions of a public character" under the internal law of the respective State and involves an independent discretion or power to act without the direct control of the delegating entity. ${ }^{205}$ Considering that States often exercise public functions when implementing the acts of an international organization, it could thus be argued that member States act as (de facto) organs of the international organization in the sense of Article 5 of the DARIO under certain circumstances.

Nonetheless, it is noteworthy that the Special Rapporteur rejected the possibility that States (or their organs) could be characterized as organs of international organization under Article 5 of the DARIO when implementing the acts of an international organization. ${ }^{206}$ In support of his argument, he cites the above-mentioned Kadi case in which the ECJ stated that "the contested regulation cannot be considered to be an act directly attributable to the United Nations as an action of one of its subsidiary organs created under Chapter VII of the Charter of the United Nations or an action falling within the

\footnotetext{
${ }^{203}$ WTO Panel Report, European Communities - Protection of Trademarks and Geographical Indications for Agricultural Products and Foodstuffs - Complaint by the United States ("EC - Trademarks and Geographical Indications (US)"), WT/DS174/R, adopted on 20 Apr. 2005, para. 7.725 [emphasis added]. The same view was taken in a panel in European Communities - Measures Affecting the Approval and Marketing of Biotech Products, WT/DS291/R, WT/DS292/R and WT/DS293/R, adopted on 29 Sept. 2006, para. 7.101.

${ }^{204}$ On this point see the comments of Austria on the DARIO on first reading, stating that draft Article 5 of the DARIO should be based on Article 5 rather than on Article 4 of the ASR. See UN Doc. A/CN.4/636 (2011), at 10.

${ }^{205}$ ILC Yearbook 2001, vol. II (Part Two), at 43 (para. 2). While Special Rapporteur Gaja stated that the term "governmental authority" could not be appropriately used with regard to international organizations, he conceded that the general rule Article 5 of the DARIO covers "all cases in which a person is entrusted with part of the organization's functions." Second Report of the Special Rapporteur on the Responsibility of International Organizations, Girgio Gaja, UN Doc. A/CN.4/541 (2004), at 28 (para. 65) [emphasis added].

${ }^{206}$ Seventh Report of the Special Rapporteur on the Responsibility of International Organizations, Giorgio Gaja, UN Doc. A CN.4/610 (2009), at 12-13 (para. 33).
} 
exercise of powers lawfully delegated by the Security Council pursuant to that Chapter”. ${ }^{207}$ While it is evident that the conduct of the European Union is not attributable to the United Nations, it is undeniable that EU member States are at the same time member States of the UN, and as such may act as de facto organs of both organizations. ${ }^{208}$ Bearing in mind that States cannot evade their international responsibility by invoking the internal law of the respective other international organization, their conduct may trigger their responsibility if they fail to reconcile their conflicting obligations at the level of implementation. ${ }^{209}$ The Special Rapporteur would certainly agree with a statement, made by the ILC in the ASR Commentary, that "international law does permit a State to escape its international responsibilities by a mere process of internal subdivision", ${ }^{210}$ be in its domestic legal order or in the internal order of an international organization. Consequently, it is suggested here that the ILC more clearly recognize that member States may be characterized as organs of an international organization, depending on the internal allocation of competences, within the meaning of Article 5 of the DARIO. ${ }^{211}$

Such a recognition that Article 5 of the DARIO intends to take account of the organic link between an international organization and its subjects, including its member States, would also contribute to the clarification of its relationship with Article 6 of the DARIO on "organs placed at the disposal of the international organization" and Article 7 of the DARIO on "excess of authority or contravention of instructions". At present, the text of Article 5 of the DARIO does not make a distinction between "organs" and "agents" of an international organization. Instead the ILC Commentary assumes that the "distinction between organs and agents does not appear to be relevant for the purpose of attribution of conduct to an international organization” with regard to Article 5 and Article 7 of the DARIO, ${ }^{212}$ a statement that has been one of the points of criticism in the DARIO on first reading. ${ }^{213}$

\footnotetext{
${ }^{207}$ Judgment (Grand Chamber) of 3 Sept. 2008, joined cases C-402/05 P and C-415/05 P, para. 314.

${ }^{208}$ In fact, it has been suggested that the organs of EU member States can be considered organs of the European Union (see the WTO Panel Report, European Communities - Protection of Trademarks and Geographical Indications for Agricultural Products and Foodstuffs - Complaint by the United States ("EC - Trademarks and Geographical Indications (US)"), WT/DS174/R, adopted on 20 April 2005, para. 7.725) and a plausible case could be made that such an organic qualification can also be applied to the normative control exercised by other international organizations with respective competences such as the UN Security Council (see Antonios Tzanakopoulos, Disobeying the Security Council. Countermeasures Against Wrongful Sanctions (Oxford: OUP 2011), at 40-42, arguing that the concept of normative control should apply to Security Council action). See Dan Sarooshi, International Organizations and Their Exercise of Sovereign Powers (Oxford: OUP 2005), 102ff., arguing that international organizations could act as de facto organs of States as a result of individual conferrals of sovereign powers.

${ }^{209}$ Special Rapporteur Gaja argues that a characterization of member State organs as organs of international organizations would contradict Article 4 of the ASR on the general rule of attribution of conduct to a State; see Seventh Report of the Special Rapporteur on the Responsibility of international Organizations, Giorgio Gaja, UN Doc. A CN.4/610 (2009), at 13 (para. 33). However, as the internal law of an international organization is not opposable to other international actors, the general rule of attribution remains applicable in cases of conflicts between treaty regimes or rather legal orders. Considering that States thus cannot avoid responsibility, they may try to change the act in question at the internal institutional level of either level. For a practical example see the discussion on the Kadi case in 2.3.2 on "Countermeasures by Member States".

${ }^{210}$ ILC Yearbook 2001, vol. II (Part Two), at 39 (para. 7).

${ }^{211}$ Shared competences may result in dual or multiple attribution as discussed in part 2.2.2 on "The Breach of a Rule of the Organization”.

${ }^{212}$ ILC Report, Sixty-first Session, UN Doc. A/64/10 (2009), at 60 (para. 5). The ILC Commentary refers mainly to the case law of the ICJ (at 59-60, para. 2-3), which has repeatedly used the term agent. However, the ICJ has also referred to State agents in cases involving conduct of State officials (e.g. organs for purposes of attribution), which has not led the ILC to distinguish between "agents" and "organs" of the State is the text of the ASR. See, for instance, the case of Military and Paramilitary Activities in and against Nicaragua case (Nicaragua v. United States of America), Judgment of 27 Jun. 1986,
} 
While it is true that such a distinction is not necessary with regard to situations involving a conferral of competences, or normative control, the term "agency" has been used in the law of international responsibility to describe a situation of factual or "effective control" that a State exercises over private persons under exceptional circumstances. ${ }^{214}$ This situation is covered in Article 8 of the ASR on "conduct directed and controlled by a State", which is to be distinguished from the preceding Articles 4 to 7 of the ASR that concern provisions on State organs. Accordingly, the general rule on attribution of conduct in Article 4 of the ASR is careful not to use the term "agent" and only refers to "organs", which it understands "in the most general sense" as including high-ranking State officials but also "organs of government of whatever kind of classification, exercising whatever functions, and at whatever level in the hierarchy, including those at the provincial level or even local level”. ${ }^{215}$ It is the necessary corollary of the corporate character of States - and international organizations - that they can only act through individuals or groups of persons. ${ }^{216}$ In contrast to the ASR, however, the DARIO on first reading do not clearly distinguish between normative and factual control in the attribution of conduct. While the reference to both "agents" and "organs" in Article 5 of the DARIO could pass as a textual omission based on pertinent ICJ case law, ${ }^{217}$ this lack of distinction may have far-reaching consequences with regard to Articles 6 and 7 of the DARIO.

In its current version Article 6 of the DARIO seems to combine Article 6 of the ASR on "conduct of organs placed at the disposal of a State by another State" with Article 8 on "conduct directed or controlled by the State" of the ASR. As a result, Article 6 of the DARIO states that the test to decide whether the acts of an organ placed at the disposal of an international organization are attributable to the organization is that of "effective control", thereby merging organic control with factual control. ${ }^{218}$ However, as the ILC Commentary to Article 8 of the ASR explains, the test of

[1986] ICJ Rep. 14, which frequently refers to a "agents" of the United States and Nicaragua in their capacity as State officials while at the same time applying the agency test of "effective control" to the contras.

${ }^{213}$ This lack of distinction was particularly criticized by international organizations in their comments on the DARIO on first reading, see UN Doc. A/CN.4/637 (2011), at 17-19.

${ }^{214}$ ILC Yearbook 2001, vol. II (Part Two), at 47 (para. 1). See also Military and Paramilitary Activities in and against Nicaragua case (Nicaragua v. United States of America), Judgment of 27 Jun. 1986, [1986] ICJ Rep. 14, at 62 and 64-65 (para. 109 and 115), and Application of the Convention on the Prevention and Punishment of the Crime of Genocide (Bosnia and Herzegovina v. Serbia and Montenegro), Judgment of 16 Feb. 2007, [2007] ICJ Rep., at 142-149 (para. 398-413).

${ }^{215}$ ILC Yearbook 2001, vol. II (Part Two), at 40 (para. 6).

${ }^{216}$ The ILC Commentary to the ASR notes that the term attribution was preferred over the equally used term "imputation" to avoid "any suggestion that the legal process of connecting conduct to the State is a fiction, or that the conduct in question is "really” that of someone else.” ILC Yearbook 2001, vol. II (Part Two), at 36 (para. 12). However, the ILC acknowledges that the recognition that the State is a "a real organized entity, a legal person with full authority to act under international law [...] is not to deny the elementary fact that the State cannot act of itself." (Ibid., at 35 (para. 5)) In explaining the concept of the act of the State, the ILC refers to the following statement by the PCIJ: "States can only act by and through their agents and representatives." (German Settlers in Poland, Advisory Opinion of 10 Sept. 1923, PCIJ Ser. B No. 6, at 22). As Stern rightly notes, "even when using the term 'attribution', the legal fiction does not become any less necessary, given that the process of attribution consists of attributing the acts of a physical person to the State, a legal person.” Brigitte Stern, 'The Elements of an Internationally Wrongful Acts', in Crawford et al., The Law of International Responsibility (Cambridge: CUP 2010) 193220, at 202.

${ }^{217}$ See supra note 212 and accompanying text.

${ }^{218}$ See in comparison the test in Article 6 of the ASR on "conduct of organs placed at the disposal of a State by another State: "The conduct of an organ placed at the disposal of a State by another State shall be considered an act of the former State under international law if the organ is acting in the exercise of elements of the governmental authority of the State at whose disposal it is placed." [Emphasis added] 
effective control does not depend on placement of an organ of the State at the disposal of another State (or subject of international law), but on the specific instructions or authorization given. ${ }^{219}$ It is therefore not surprising that the ECtHR confused normative and effective control in its controversial Behrami and Saramati judgement, ${ }^{220}$ or that the UN criticized the approach taken by the ILC to use the terms "agent” and "organ” interchangeably. As the UN pointed out in its Comments to the DARIO on first reading: "While an 'agent' may or may not be contractually linked to the United Nations, an 'organ' must maintain an 'organic link' to the Organization to be considered as such by the Organization.”221 On this basis, the UN argued that peace operations placed at the disposal of the United Nations are "transformed" into subsidiary organs under the "effective command and control" of the UN in the sense of Article 5 of the DARIO, and are to be distinguished from UN-authorized military operations. ${ }^{222}$ In order to address this fundamental criticism by the United Nations, it may not be sufficient to delete the unnecessary reference to "agents" in Article 5 of the DARIO. The ILC may additionally have to reformulate Article 6 so as to resemble more closely Article 8 of the ASR, and recognize that Article 5 of the DARIO covers the conduct of peace operations to the extent that the organization has functional competence as delimited by its constitution. ${ }^{223}$

The distinction between "organ" and "agent" for the purposes of attribution of conduct in Articles 5 and 6 of the DARIO could finally also elucidate the scope of the ultra vires principle in Article 7 of the DARIO, which appears to reflect Article 7 of the ASR. It is suggested accordingly that the conduct of member States is only attributable to the international organization when they act as organs of the organization, even when acting ultra vires or in excess of the instructions given to them. As the ILC Commentary to Article 7 of the ASR observes, the situation of factual control under Article 8 of the ASR is covered by the more specific provision. Considering that the ILC does not clearly distinguish between factual and normative control in the DARIO, the corresponding Commentary on first reading does not include a comparable statement. ${ }^{224}$ However, the second reading of the DARIO would offer the ILC an important opportunity to make a contribution to the longstanding and difficult debate on the ultra vires acts of international organizations by acknowledging that these acts are of part an international organization's internal legal order. ${ }^{225}$

\footnotetext{
${ }^{219}$ ILC Yearbook 2001, vol. II (Part Two), at 48 (para. 7 and 8).

${ }^{220}$ Behrami v. France (application no. 71412/01) and Saramati v. France, Germany and Norway (no. 78166/01), European Court of Human Rights, Grand Chamber, 2 May 2007.

${ }^{221}$ See UN Doc. A/CN.4/637/Add.1 (2011), at 14 (para. 14).

${ }^{222}$ See UN Doc. A/CN.4/637/Add.1 (2011), at 15-17.

${ }^{223}$ Considering its substantial criticism, it is surprising that the UN "nevertheless supports the inclusion of Article 6 in the draft Articles as a general guiding principle in the determination of responsibilities between the United Nations and its member States with respect to organs or agents placed at the disposal of the Organization." UN Doc. A/CN.4/637/Add.1 (2011), at 17 (para. 7).

${ }^{224}$ While the ILC Commentary observes that "Article 7 has to be read in the context of the other provisions relating to attribution, especially article 5", it also notes that a "distinction between the conduct of organs and officials and that of other agents would find little justification in view of the limited significance that the distinction carries in the practice of international organizations.” ILC Report, Sixty-first Session, UN Doc. A/64/10 (2009), at 72 (para. 7). As discussed supra with regard to Article 5 and 6 of the DARIO, this statement evidently fails to distinguish between the colloquial use of the terms "agent" and "organ", which is similar with regard to States, and the legal significance of these in the terms in the law of international responsibility.

${ }^{225}$ As the ICJ stated in the Certain Expenses case: "If it is agreed that the action in question is within the scope of the
} 


\subsubsection{The Breach of a Rule of the Organization}

Article 9 (2) of the DARIO provides that a breach of an international obligation by the international organization "may arise from the rules of the organization”. As the Commentary explains, paragraph 2 of Article 9 "simply intends to say that, to the extent that an obligation arising from the rules of the organization has to be regarded as an obligation under international law, the principles expressed in the present article apply."226 Article 9 (2) accordingly seems to be based on two assumptions: first, that the rules of the organization are at least partly international law; and second, that the international organization is bound by these rules in their international dimension.

Considering the dual nature of the rules of the organization, it is clear that Article 9 (2) of the DARIO conflates the constitutional and contractual nature of the constituent instruments. While the constituent instruments may be international in their contractual dimension, as contracts between States, the rules of the organization do not have an international nature for the organization itself. As an international organization is not a party to its own constituent instruments, it may only be bound by its constituent instrument in its constitutional dimension and in its capacity as a treaty. ${ }^{227}$ This conclusion also seems to find authoritative support in the following well-known passage by the ICJ in its Advisory Opinion on the Agreement of 25 March 1951 between the WHO and Egypt:

"International organizations are subjects of international law and, as such, are bound by any obligations incumbent upon them under general rules of international law, under their constitutions or under international agreements to which they are parties."228

In this passage the ICJ appears to make a distinction between an international organization's internal constitutional relations and its international contractual relations with third parties. In his third report on the responsibility of international organizations, the ILC Special Rapporteur Giorgio Gaja acknowledged that this statement by the ICJ in its Nuclear Weapons Advisory Opinion would speak in favor of the internal nature of the rules of the organization. He nonetheless decided to give precedence

functions of the Organization but it is alleged that it has been initiated or carried out in a manner not in conformity with the division of functions among the several organs which the Charter prescribes, one moves to the internal plane, to the internal structure of the Organization. If the action was taken by the wrong organ, it was irregular as a matter of that internal structure, but this would not necessarily mean that the expense incurred was not an expense of the Organization. Both national and international law contemplate cases in which the body corporate or politic may be bound, as to third parties, by an ultra vires act of an agent." Certain Expenses of the United Nations, Advisory Opinion of 20 July 1962, [1962] ICJ Rep. 151, at 168. On ultra vires acts of international organizations see generally Hersch Lauterpacht, 'The Legal Effect of Illegal Acts of International Organizations', in Cambridge Essays in International Law. Essays in Honour of Lord McNair (London: Stevens \& Sons 1965); J.E.S. Fawcett, 'Détournement de Pouvoir by International Organizations', (1957) 33 BYIL 311-316; Felice Morgenstern, 'Legality in International Organizations', (1976-1977) 48 BYIL 241-257; Eberke Osieke, 'The Legal Validity of Ultra Vires Decisions of International Organizations', (1983) 77 AJIL 239-256.

${ }^{226}$ ILC Report, Sixty-first Session, UN Doc. A/64/10 (2009), at 79 (para. 6).

${ }^{227}$ Judge Spender therefore stated in his separate opinion in the Certain Expenses case that an organ of the UN is "not a party to the UN Charter”. Certain Expenses of the United Nations, Advisory Opinion of 20 July 1962, [1962] ICJ Rep. 151 , at 192. See also Patrick Daillier, 'Article 5 - Convention de 1969', in Oliver Corten and Pierre Klein (eds.), Les Conventions de Vienne sur le Droit des Traités : Commentaire article par article, Vol. I (Bruxelles: Bruylant 2006), 137-157, at 141; and Catherine Brölmann, 'International Organizations and Treaties: Contractual Freedom and Institutional Constraint, in Jan Klabbers and Asa Wallendahl (eds.), Research Handbook on International Organizations (Cheltenham: Elgar Publishers 2011) 285-312, at 285.

${ }^{228}$ Interpretation of the Agreement of 25 March 1951 between the WHO and Egypt, Advisory Opinion of 20 Dec. 1980 , [1980] ICJ Rep. 73, at 89-90 (para. 37). 
to the contentious Lockerbie case in which the ICJ dealt with, "rules of the organization other than the constituent instruments”, namely Security Council resolutions. ${ }^{229}$ Underlining that the ICJ regarded obligations under a resolution as prevailing over obligations under a treaty, the Special Rapporteur concluded that certain "rules of the organization are part of international law at least insofar as the United Nations is concerned.”230

Considering that the Lockerbie case concerned the obligations of UN member States under two conflicting treaty regimes, the UN Charter and the Montreal Convention, it can be reasonably argued that the Court only pronounced itself on the international rules of the organization in their contractual dimension, as a treaty between UN member States. As a result and contrary to the assumption of the Special Rapporteur, the Lockerbie case does not speak in favor of the possibility that an international organization may incur responsibility for a breach of its own rules as suggested by Article 9 (2) of the DARIO. The rules of the organization may contain special rules on the existence of a breach, as underlined by the ILC Commentary; ${ }^{231}$ however, such special rules only pertain to the member States of an international organization, which could be held internationally responsible for a breach of their contractual obligations if the special procedures fail to remedy the breach internally. Since the ASR already cover the breach of an international obligation by States in Part One, Chapter III, it is accordingly suggested that Article 9 (2) of the DARIO should be deleted. ${ }^{232}$

As in the law of State responsibility, the question whether or not an internal act of the organization will result in the responsibility of the international organization ultimately depends on the respective primary obligation. In this context, Article 9 (1) is sufficient to cover situations in which the conduct required of an international organization by an international obligation and the conduct actually adopted - i.e. the requirements of international law and the facts of the matter - are not in conformity with each other. ${ }^{233}$ However, unlike the law of the State responsibility, the law of the responsibility of international organizations has to accommodate the fact that international organizations are unitary actors with functional limitations. By indicating the division of competences between an international organization and its member States, the internal law of the organization is therefore decisive for the determination of the entity on which the primary obligation breached is effectively incumbent. In other words, the internal law of the organization indicates whether the member State is acting as an organ or agent of the organization, or whether it is simply following a recommendation by the international organization with full implementing discretion. In this sense, the

\footnotetext{
${ }^{229}$ Third Report of the Special Rapporteur on the Responsibility of International Organizations, Giorgio Gaja, UN Doc. A/CN.4/553 (2011), at 8 (para. 20).

230 Ibid.

${ }^{231}$ ILC Report, Sixty-first Session, UN Doc. A/64/10 (2009), at 79 (para. 7).

${ }^{232}$ The same suggestion is made by the World Bank in its comments on the DARIO on first reading, see UN Doc. A/CN.4/637 (2011), at 25-26; see also the critical comments by the EU at 24-25.

${ }^{233}$ This formulation is taken over from the ILC Commentary to Article 12 of the ASR. ILC Yearbook 2001, vol. II (Part Two), at 54 (para. 2).
} 
division of competences is intrinsically linked or even precedes the attribution of conduct discussed above. $^{234}$

In view of the fact that most international organizations do not have competences other than those pertaining to their effective functioning, the number of cases in which international organizations may incur responsibility is limited - a finding that may explain the often criticized scarcity of practice on the subject-matter of the DARIO and the frequency of references to EU examples in the ILC Commentary. States usually only delegate their sovereign powers to international organizations, and continue to exercise these powers concurrently with the international organization. If a member State violates an international obligation while implementing legislation of an international organization in an area of concurrent competences ${ }^{235}$ and if this obligation equally binds the organization, both the member State and the international organization incur shared responsibility for the complex internationally wrongful act(s) causing the injury based on concurrent attribution. ${ }^{236}$ As the ILC recognizes in its Commentary to Article 2 (a) of the DARIO, the existence of a distinct legal personality of the international organization "does not exclude the possibility of a certain conduct being attributed both to the organization and to one or more of its members or to all its members.”237

The EU is at present the only international organization to which member States have completely transferred their powers in certain areas. It could accordingly be contended that the obligation breached is only incumbent upon the organization. Consequently, it is not surprising that the EU has generally accepted to act on behalf of its member States in the framework of the WTO dispute settlement system. However, even the European Union still exercises many of its competences is a parallel or shared manner with its member States, which has necessarily resulted in case-by-case decisions on whether an obligation is binding for both the EU and its member States or only one of

\footnotetext{
${ }^{234}$ In a similar vein, this argument is made with regard to the EC by Esa Paasivirta and Pieter Jan Kuijper, 'Does One Size Fit All?: The European Community and the Responsibility of International Organizations', in (2005) 36 Netherlands Yearbook of International Law 169-226, at 216. Some authors maintain the two elements of an internationally wrongful act are "paradoxically inverted". For a discussion see Brigitte Stern, 'The Elements of an Internationally Wrongful Acts', in Crawford et al., The Law of International Responsibility (Cambridge: CUP 2010) 193-220, at 201-202.

235 The term "current competences" is used here instead of "shared competences" or "parallel competences", which are distinctive terms in EU law. For a differentiation with regard to the law of responsibility see Frank Hoffmeister, 'Litigating against the European Union and Its Member States - Who Responds under the ILC's Draft Articles on International Responsibility of International Organizations?’, (2010) 21 EJIL 723-747, at 743.

${ }^{236}$ The situation of "composite legal acts" committed by one State is covered in Article 15 of the ASR. On complex legal acts in the law of State responsibility see Jean J. A. Salmon, 'Le fait étatique complexe: une notion contestable', (1982) 28 Annuaire francais de droit international 709-738. It is beyond the scope of this paper to discuss the different scenarios of shared responsibility between two autonomous entities in terms of attribution of conduct and responsibility. However, it is noteworthy that both the ASR and DARIO envisage the possibility of shared responsibility either in the ILC Commentary or directly in text of the provisions. Moreover, the importance of multiple attribution of conduct and responsibility finds increasing recognition in legal scholarship. See generally Pierre Klein, 'The Attribution of Acts to International Organizations', in James Crawford et al. (eds), The Law of International Responsibility (Oxford University Press, Oxford 2010), 298-315, at 306ff; Christian Dominicé, 'Attribution of Conduct to Multiple States and the Implication of a State in the Act of Another State’, in James Crawford et al. (eds), The Law of International Responsibility (Oxford University Press, Oxford 2010); and in particular the literature on peace operations Aurel Sari, 'Jurisdiction and International Responsibility in Peace Support Operations: The Behrami and Saramati Cases', (2008) 8 Human Rights Law Review 151-170; Tom Dannenbaum, 'Translating the Standard of Effective Control into a System of Effective Accountability. How liability should be apportioned for violations of human rights by Member State Troop Contingents Serving as United Nations Peacekeepers', (2010) 51 Harvard Journal of International Law 113-192; Kjetil Mujezinovic Larsen, 'Attribution of Conduct in Peace Operations : The 'Ultimate Authority of Control' Test', (2008) 19 EJIL 509-531.

${ }^{237}$ ILC Report, Sixty-first Session, UN Doc. A/64/10 (2009), at 48 (para. 10).
} 
them. ${ }^{238}$ In order to reduce legal uncertainty for third parties, the European Union has therefore developed a practice in which special "declarations of competence" are attached to international agreements to which the European Union and/or its member States are a party. ${ }^{239}$ Situations lacking such an implicit or explicit declaration will usually result in cases of shared responsibility. As the European Court of Justice stated in one of the cases Parliament v. Council, concerning a treaty establishing cooperation with non-EU member States that was concluded by both the (then) European Community and its member States:

"In those circumstances, in the absence of derogations expressly laid down in the Convention, the Community and its Member States as partners of the ACP States are jointly liable to those latter States as partners of the ACP States for the fulfilment of every obligation arising from the commitments undertaken, including those relating to financial assistance."240

Interestingly, this passage is also cited by the ILC in its Commentary to Article 9 (2) of the DARIO as an example of a situation in which the organization is under an obligation to achieve a certain result irrespective of whether the necessary conduct will be taken by the organization itself or by one or more of its Member States. ${ }^{241}$ Yet, as the EU rightly criticized in its comments on the DARIO on first reading, "all the treaty obligations bind both the European Union and its Member States irrespective of the exact internal delimitation of competences". ${ }^{242}$ The internal law of the organization, and in particular the distribution of competences between the international organization and its member States, is not opposable to third parties, unless these third parties explicitly agree. Speaking in contractual terms, the constituent instruments of an international organization are res inter alios acta for third parties, unless these third parties give their consent thereto. If States contract out of the general regime of responsibility in a specific field such as trade or fisheries, this contract is not opposable to third parties to which member States may owe customary or treaty obligations. ${ }^{243}$ The EU's declarations of competence can thus be understood as a requirement of the principle of effectiveness in the still decentralized international legal order. ${ }^{244}$

\footnotetext{
${ }^{238}$ See Frank Hoffmeister, 'Litigating against the European Union and Its Member States - Who Responds under the ILC’s Draft Articles on International Responsibility of International Organizations?’, (2010) 21 EJIL 723-747, at 744.

${ }^{239}$ In these "mixed agreements" EU member States thus "remain internationally in the picture”, as described by Pieter Jan Kuijper in 'Of 'Mixety' and 'Double Hatting', Inaugural Lecture, University of Amsterdam (2008). On the practice of declarations of competence with regard to the international responsibility of the EU (then EC) see Esa Paasivirta and Pieter Jan Kuijper, 'Does One Size Fit All?: The European Community and the Responsibility of International Organizations', in (2005) 36 Netherlands Yearbook of International Law 169-226, at 185-188. On mixed agreements and third parties see generally Joni Heliskoski, Mixed Agreements as a Technique for Organizing the International Relations of the European Community and its Member States (The Hague: Kluwer 2002).

${ }^{240}$ Case C-316/91, Judgment of 2 March 1994, European Court of Justice Report, 1994, at I-625 at I-660-661. [emphasis added] The case is interestingly also cited by the ILC in its Commentary to Article 9 (2) as an example of an obligation

${ }^{241}$ ILC Report, Sixty-first Session, UN Doc. A/64/10 (2009), at 80, para. (9).

${ }^{242}$ See UN Doc. A/CN.4/637 (2011), at 25 (para. 3) [emphasis added].

${ }^{243}$ See Article 34 to 38 of the VLCT on Treaties and Third Parties. Many constituent instruments of international organizations give third parties the possibility to address violations of their (international) contractual relations in within the institutional system of the organization.

${ }^{244}$ See Ian Brownlie, 'State Responsibility: The Problem of Delegation', in Konrad Ginther et al. (eds.), Völkerrecht zwischen normativem Anspruch und politischer Realität (1994), 300-301, emphasizing that a "State cannot by delegation (even if this be genuine) avoid responsibility for breaches of its duties under international law. [...] This approach of public international law is not ad hoc but stems directly from the normal concepts of accountability and effectiveness.”
} 


\subsection{LEGAL CONSEQUENCES OF WRONGFUL CONDUCT}

The characterization of the "rules of the organization" as internal law of the organization is equally relevant for the legal consequences of wrongful conduct. Considering that the ILC decided not to include a provision similar to Article 3 of the ASR into the DARIO with regard to the conditions of wrongful conduct, it is significant that it opted for including a provision that replicates Article 32 of the ASR on the "irrelevance of internal law" with regard to the legal consequences of internationally wrongful conduct. ${ }^{245}$ Article 31 (1) accordingly reads:

"The responsible international organization may not rely on its rules as justification for failure to comply with its obligations under this Part.”

However, unlike Article 32 of the ASR, Article 32 of the DARIO has a paragraph 2, which stipulates that the principle contained in paragraph 1 is "without prejudice to the rules of an international organization in respect of the responsibility of the organization towards its member States and organizations". As the ILC Commentary to Article 31 of the DARIO explains its decision to include paragraph 2, the rules of the organization may modify the rules on the forms of reparation that a responsible international organization may have to make towards its members. ${ }^{246}$ Article 31 (2) thus suggests that the rules of the organization could be international law and as such not be irrelevant for the obligation to make reparation that an international organization may owe to States under international law if these States are also its members.

The rules applicable between an international organization and a member State do provide for different special legal consequences in relation to the general rules on the responsibility of international organizations. However, although these differences have their origin in the constituent instruments, they are part of the internal constitutional law of the organization and not part of international law during the life of the organization. ${ }^{247}$ Since these internal dynamics cannot be covered by the general rules on responsibility, the reservation in Article 32 (2) of the DARIO is unnecessary and should be eliminated from the DARIO on second reading. ${ }^{248}$ An international organization has an obligation to make full reparation as a result of a breach of its international obligations towards third parties, which is to be distinguished from the collective obligation that the contracting parties to the constituent instruments have towards each other in terms of providing the organization with the necessary resources (2.3.1). A member State may disobey an internal rule of an international organization, for instance, by withholding membership contributions. However, considering that the international organization is an autonomous legal order, these measures are not countermeasures against the international organization but rather they are acts of "institutional disobedience” against the constituted polity. Only if the autonomy of an international organization is effectively diminished may States resort to countermeasures under general international law, not

\footnotetext{
${ }^{245}$ Article 32 of the Articles of State Responsibility on "Irrelevance of internal law” provides: “The responsible State may not rely on provisions of its internal law as justification for failure to comply with its obligations under this Part.”
} 
against the international organization but against the other contracting parties to the constituent instruments (2.3.2).

\subsubsection{The Obligation to Provide Reparation}

In following the model of Article 31 of the ASR, Article 30 (1) of the DARIO states that:

"The responsible international organization is under an obligation to make full reparation for the injury caused by the internationally wrongful act."

The ILC Commentary explains that the principle of full reparation in Article 30 of the DARIO mainly refers to "the more frequent case in which an international organization is solely responsible for an internationally wrongful act”, and admits that this principle does not necessarily apply when an international organization incurs responsibility in connection with the act of a State. ${ }^{249}$

Considering that most international organizations exercise their competences concurrently with States, it is submitted that situations of shared responsibility - as a result of concurrent attribution of conduct (or responsibility) - will occur more frequently than those of individual responsibility of the international organization. Cases such as M. \& Co. v. Germany, or Behrami and Saramti v. France and Norway, for instance, could be examples of such shared responsibility, ${ }^{250}$ if the respective international organization would have been a party to the European Convention on Human Rights. While the implementation of responsibility between an international organization and its member States will often fail due to jurisdictional limitations of the respective judicial mechanisms, it is noteworthy that the implementation of responsibility is not a decisive criterion in the ILC's conception of "objective responsibility”. ${ }^{251}$ As the ILC Commentary to Article 31 of the ASR explains, the general obligation of reparation is formulated as the "immediate corollary of a State's responsibility, i.e. as an obligation of the responsible State resulting from the breach, rather than as a right of an injured State or States."252 Even if an injured State only invokes the responsibility of one entity, either the member State or the international organization, the respective other entity remains responsible and

\footnotetext{
${ }^{246}$ ILC Report, Sixty-first Session, UN Doc. A/64/10 (2009), at 114 (para. 3).

${ }^{247}$ With regard to breaches of an international legal obligation owed by the international organization towards one of its member States as a third party, the legal consequences set out in the DARIO are applicable. If the organization and the member State conclude an international agreement on special legal consequences, this agreement would qualify as lex specialis in a horizontal dimension (as used in Article 55 of the DARIO).

${ }^{248}$ In fact, by maintaining paragraph 2 as it stands, the ILC wrongly suggests that the rules on the responsibility of international organization, including countermeasures, may at least be residually relevant with regard the legal consequences incurred by an international organization in relation to its member States. On this point, see the questions raised by the ILC in commenting on the DARIO on first reading, see UN Doc. A/CN.4/637 (2011), at 31.

${ }^{249}$ ILC Report, Sixty-first Session, UN Doc. A/64/10 (2009), 112 (para. 2).

${ }^{250}$ M. \& Co. against the Federal Republic of Germany (application no. 13258/87), European Commission of Human Rights, 9 Feb. 1990; Behrami v. France (application no. 71412/01) and Saramati v. France, Germany and Norway (no. 78166/01), European Court of Human Rights, Grand Chamber, 2 May 2007.

${ }^{251}$ This conceptual "revolution” was brought about by Roberto Ago by formulating Article 1 of the ASR as follow: "Every internationally wrongful act of a State entails the international responsibility of that State.” Injury (be it material or moral), which had constituted the basis of the previous Special Rapporteur Garcia Amador, was not considered as the trigger of international responsibility anymore. See Alain Pellet, 'The ILC's Articles on State Responsibility', in James Crawford et al. (eds.), The Law of International Responsibility (Oxford: OUP 2010), 75-94, at 76-77.

${ }^{252}$ ILC Yearbook 2001, vol. II (Part Two), at 91 (para. 4).
} 
may be equally subject to claims according to Articles 47 of the ASR and DARIO, respectively, on the plurality of responsible actors. ${ }^{253}$

If the international organization alone is held responsible, it may be faced with the problem of insufficient financial means due to its dependency of the contributions of member States. The concern that the lack of financial resources of an international organization could leave its creditors emptyhanded dates back to the well-known collapse of the International Tin Council (ITC) and the ensuing litigation mainly before British courts. ${ }^{254}$ The ITC cases preluded an intense scholarly debate questioning under which circumstances the member States of an international organization can be held responsible for the actions of an international organization. ${ }^{255}$ Nonetheless, although the Institut de droit international in its work on "Liability to Third Parties of Member States of International Organizations” excluded responsibility by membership alone, ${ }^{256}$ the ILC chose to make an explicit provision in the DARIO on the role of member States in "ensuring the effective performance of the obligation of reparation” by an international organization. As Article 39 of the DARIO stipulates:

"The members of a responsible international organization are required to take, in accordance with the rules of the organization, all appropriate measures in order to provide the organization with the means for effectively fulfilling its obligations under this chapter."

The ILC Commentary emphasizes that Article 39 is of an "expository character" and does not intend to create any further instances in which States would be held internationally responsible for the act of an organization of which they are members. ${ }^{257}$ The basis of this obligation is rather to be found in the rules of the organization applicable between the members and the organization. ${ }^{258}$ For purposes of

\footnotetext{
${ }^{253}$ A discussion of the controversial modes of implementation of responsibility is beyond the scope of this paper. For an overview of the different principles to allocate shares of responsibility to multiple actors see André Nollkaemper, 'Issues of Shared Responsibility before the International Court of Justice', (2011) ACIL Research Paper (SHARES Series) No. 1.; Alexander Orakhelashvili, 'Division of Reparation between Responsible Entities' in James Crawford et al. (eds.), 'The Law of International Responsibility (Oxford University Press, Oxford 2010).

${ }^{254}$ The ITC cases therefore mainly concerned questions of the liability of member States under British domestic law, see, J.H. Rayner (Mincing Lane) Ltd v. Department of Trade and Industry and others and related appeals; Maclaine Watson \& Co Ltd v. Department of Trade and Industry, and Maclaine Watson \& Co. Ltd v. International Tin Council, decision of 26 October 1989, House of Lords, in 81 ILR 670, at 678.

${ }^{255}$ On the ITC cases see generally Romana Sadurska and Christine Chinkin, 'The Collapse of the International Tin Council: A Case of State Responsibility?', (1989-1990) 30 Virginia Journal of International Law 845-890; C.F. Amerasinghe, 'Liability to Third Parties of Member States of International Organizations: Practice, Principle and Judicial Precedent', (1991) 85 AJIL 259-280; Ingolf Pernice, 'Die Haftung internationaler Organisationen und ihrer Mitglieder, dargestellt am “Fall” des internationalen Zinnrates’, (1988) 26 Archiv des Völkerrechts 406-433. The ITC case are often discussed in conjunction with the Westland Helicopters arbitration (Westland Helicopters Ltd and Arab Organization for Industrialization, United Arab Emirates, Kingdom of Saudi Arabia, State of Qatar, Arab Republic of Egypt and Arab British Helicopter Company, award of 5 March 1984, in 80 ILR 47), see exemplarily Pierre Klein, La responsabilité des organisations internationales dans les ordres juridiques internes et en droit des gens (Bruylant, 1998), 434; Chinkin and Sadurska, 'The Collapse of the International Tin Council: A Case of State Responsibility?', (1989-1990) 30 Virginia Journal of International Law 845-890, at 876.

${ }^{256}$ In Article 6 (a) of its 1995 Resolution the Institut de droit international ((1996) 66-II Annuaire de l'Institut de Droit International 249-469, at 466) stated that "[t]here is no general rule of international law whereby States members are, due solely to their membership, liable, concurrently or subsidiarily, for the obligations of an international organization of which they are members". For a critical assessment of the work of the Institut de droit international see Andrew Stumer, 'Liability of Member States for Acts of International Organizations: Reconsidering the Policy Objections', (2007) 48 Harvard International Law Journal 553-580.

${ }^{257}$ ILC Report, Sixty-first Session, UN Doc. A/64/10 (2009), at 123.

${ }^{258}$ Support for the reference to the "rules of the organization" can be found in statements of the following countries in the Sixth Committee: Denmark, on behalf of the Nordic countries (Denmark, Finland, Iceland, Norway and Sweden)
} 
Article 39 of the DARIO the ILC thus seems to characterize the rules of organization to be internal law of the organization.

However, due to the ambiguity of the term "rules of the organization" Article 39 of the DARIO could also be understood as giving rise to international obligations for member States, especially if read against the background of Article 32 (2) of the DARIO on the possible relevance of the rules of the organization for the duty to make reparation. The proposition that member States have an international obligation to finance an international organization would certainly meet with some opposition. In fact, a counter-proposal for Article 39 was made in the ILC, which suggested that the international organization itself should ensure that its members provide it with the necessary means for the effective provision of reparation. ${ }^{259}$ Nonetheless, considering the dual nature of the constituent instruments, it could indeed be argued that the ILC has overlooked that the member States of an international organization may have an international obligation to furnish it with the necessary financial resources to ensure its effective functioning, that is its very existence. ${ }^{260}$ As Judge Fitzmaurice summarized the collective obligations flowing from the rules of the organization in his separate opinion in Certain Expenses of the United Nations case:

Without finance, the Organization could not perform its duties. Therefore, even in the absence of Article 17, paragraph 2, a general obligation for Member States collectively to finance the Organization would have to be read into the Charter, on the basis of the same principle as the Court applied in the Injuries to United Nations Servants case, namely 'by necessary implication as being essential to the performance of its [i.e. the Organization's] duties'. ${ }^{261}$

The failure to finance an international organization will eventually diminish its autonomy so that it can no longer function effectively and may ultimately be terminated de jure or de facto. Consequently, the contracting parties to the constituent instruments re-appear behind the constitutional veil of the organization. In this sense, it could be argued that the termination of the international organization due to a lack of resources or another failure on the part of its member States - will result in the collective responsibility of the contracting parties to its constituent instruments, so as to avoid a legal vacuum for injured third parties. As the ILC explains in its Commentary to Article 30 of the DARIO, the inadequacy of its financial resources cannot exempt an international organization from the legal consequences resulting from its responsibility under international law. ${ }^{262}$ By taking into account the dual nature of the constituent instruments in re-considering the DARIO on second reading, the ILC

(A/C.6/61/SR.13, para. 32); Belgium (A/C.6/61/SR.14, para. 42); Spain (ibid., para. 53); France (ibid., para. 63); and Switzerland (A/C.6/61/SR.15, para. 5). The ILC Commentary also mentions the work of the Institut de Droit International, which held that an obligation to put a responsible organization in funds only existed "pursuant to its Rules" ((1996) 66-II Annuaire de l'Institut de Droit International 249-469, at 451).

${ }^{259}$ ILC Report, Sixty-first Session, UN Doc. A/64/10 (2009), at124 (para. 4).

${ }^{260}$ See Jose Alvarez, 'Legal Remedies and the United Nations à la Carte Problem', (1990-1991) Michigan Journal of International Law 229-311, at 290; see also the propositions made by C. Wilfred Jenks, 'Some Aspects of the Financing of International Institutions', (1942) 42 Transactions of the Grotius Society 87-132, at 100-101.

${ }^{261}$ Certain Expenses of the United Nations, Advisory Opinion of 20 July 1962, [1962] ICJ Rep. 151, at 208, referring to Reparation for Injuries Suffered in the Service of the United Nations, Advisory Opinion of 11 Apr. 1949, [1949] ICJ Rep. 174 , at 182 .

${ }^{262}$ ILC Report, Sixty-first Session, UN Doc. A/64/10 (2009). 
could thus make an important distinction: Whereas the internal law of the organization is irrelevant for the provision of reparation by an international organization, its member States have a mutual contractual obligation to provide the organization with the necessary means to ensure the effectiveness of their contractual obligations.

\subsubsection{Countermeasures by Member States}

The recognition of the dual nature of the constituent instruments, which are constitutions but have an underlying contractual dimension, would also clarify the situation that is described by the ILC as “countermeasures by members of an international organization”. As Article 51 of the DARIO states:

An injured State or international organization which is a member of a responsible international organization may not take countermeasures against that organization under the conditions set out in the present Chapter unless:

(a) The countermeasures are not inconsistent with the rules of the organization; and

(b) No appropriate means are available for otherwise inducing compliance with the obligations of the responsible organization under Part Three.

Article 51 of the DARIO subjects the admissibility of countermeasures by members against an international organization to the rules of the organization, by using a complicated double negation and without qualifying whether these rules are of a contractual or constitutional nature. ${ }^{263}$

In view of the dual nature of the constituent instruments, it is suggested that Article 51 fails to make the crucial distinction between the internal constitutional relations between an international organization and its members, and the external relations that an international organization may have with other subjects of international law, including its member States in their capacity as States. It is true that the constituent instruments of some international organizations explicitly prohibit the taking of countermeasures in the framework of the organization; ${ }^{264}$ however, an international organization itself is not a contracting party to its constituent instruments under international law despite the fact that these instruments serve as its constitution under internal law. ${ }^{265}$ Accordingly, such prohibitions are only applicable between the member States of the organization in their mutual contractual relations and are not due to the international organization itself. In fact, as an autonomous entity, the international organization is charged with the supervision of its member States in order to avoid

\footnotetext{
${ }^{263}$ See also Article 21 of the DARIO on countermeasures as a circumstance precluding wrongfulness. Paragraph 2 mirrors Article 51 of the DARIO in the reverse direction. In other words, it conditions the use of countermeasures by an international organization against a member or international organization by virtue of the rules of the organization. The considerations expressed in this section with regard to countermeasures by members (Article 51 of the DARIO) are equally relevant for Article 21 (2) of the DARIO.

${ }^{264}$ As the ECJ stated: “[...] except where otherwise expressly provided, the basic concept of the [EEC] Treaty requires that the member States shall not take the law into their own hands. Therefore the fact that the Council failed to carry out its obligations cannot relieve the defendants from carrying out theirs.” Judgment of 13 November 1964, Commission of the European Economic Community v. Grand Duchy of Luxembourg and Kingdom of Belgium, joined cases 90/63 and 91/63, European Court of Justice Reports, 1964, p. 1201 [French edition]. For a discussion of countermeasures in relation to specialized regimes see Bruno Simma and Dirk Pulkowski, 'Of Planets and the Universe: Self-contained Regimes in International Law', (2006) 17 EJIL 483-529; and Christian Tams, 'Unity and Diversity in the Law of State Responsibility', in Andres Zimmermann and Rainer Hofmann (eds.), Unity and Diversity in International Law (Berlin: Duncker \& Humblot 2005) 437-470.

${ }^{265}$ For a discussion see section 2.2.2. on the "Breach of a Rule of the Organization” in this paper.
} 
breaches of their mutual obligations or to address them by means of sanctions, ${ }^{266}$ which can be defined as "a coercive response to an internationally wrongful act authorised by a competent social organ”. ${ }^{267}$ In contrast, countermeasures are instruments of private justice and self-help, which are diametrically opposed to the public purpose of international organizations to foster their members' cooperation within its internal constitutional order. ${ }^{268}$ Commenting in the Sixth Committee of the UN General Assembly, as Germany, France and Greece therefore rightly emphasized "as a general rule, [that] countermeasures had no place in the relations between an international organization and its members". 269

Nevertheless, in their external or international relations, member States may take countermeasures against the international organization with regard to a breach of their reciprocal horizontal engagements based on international agreements or customary international law. As a consequence of its legal personality, an international organization co-exists with its member States when they act in their capacity as States. Nonetheless, (member) States are unlikely to take countermeasures against an international organization for a breach of an international obligation owed to States by that organization because such measures would impede on the effective functioning of the organization. As Article 50 of the DARIO on the object and limits of countermeasures states, countermeasures "shall, as far as possible, be taken in such a way as to limit their effects on the exercise by the responsible international organization of its functions”. Since third parties other than the member States do not have a direct interest in the effective functioning of an international organization, this limitation is particularly relevant for - and possibly only applicable to (member) States in their external relations with an international organization. ${ }^{270}$ As the ILC stated in its work on the law of treaties, the member States of an international organization are "not exactly third States like the rest”, ${ }^{271}$ due to their correlative constitutional relationship with the organization. It could

\footnotetext{
${ }^{266}$ On "sanctions and supervision" by international organizations see generally Henry G. Schermers and Niels M. Blokker, International Institutional Law: Unity within Diversity (Boston: Martinus Nijhoff Publishers 2003), stating at 873 (para. 1390) that it "is generally recognized that one of the main tasks of international organizations is to supervise compliance with their rules."

${ }^{267}$ James Crawford, 'The Relationship between Sanctions and Countermeasures', in Vera Gowlland-Debbas (ed.), United Nations Sanctions and International Law (Kluwer, The Hague, 2001) 57-68, at 57, referring to Georges Abi-Saab, 'The Concept of Sanction in International Law', in Vera Gowlland-Debbas (ed.), United Nations Sanctions and International Law (Kluwer, The Hague, 2001), 29-41. See also Sicilianos who, in explaining the distinction between inter-state countermeasures and sanctions, distinguishes the relational and the institutional link, states that "les premiers créent des rapports 'horizontaux' entre l'État auteur du fait illicite et les États qui réagissent, alors que les seconds font naître des relations pour ainsi dire 'verticales' entre l'État membre [...] et l'Organisation [internationale]'. Linos-Alexandre Sicilianos, 'La codification des contre-mesures par la Commission du droit international', (2005) 38 Revue belge de droit international 447-500, at 487.

${ }^{268}$ On this point see Denis Alland, 'Countermeasures of General Interest', (2002) 13 EJIL 1221-1239, at 1223, stating that countermeasures are "mechanisms of private justice that find their raison d'être in the failure of institutions”.

${ }^{269}$ UN Doc A/C.6/63/SR.19 (Germany), UN Doc A/C.6/63/SR.20 (France), UN Doc A/C.6/63/SR.21 (Greece). See also the Comments by Germany and the EU on the DARIO on first reading, UN Doc. A/CN.4/636 (2011), at 32, and UN Doc. A/CN.4/637 (2011), at 35.

${ }^{270}$ The ILC Commentary additionally explains that certain functions by an international organization may be of vital interest to its member States and in certain cases to the international community. ILC Report, Sixty-first Session, UN Doc. A/64/10 (2009), at 159 (para. 7).

${ }^{271}$ ILC Commentary to Article 46 of the draft Articles on the Law of Treaties between States and International Organizations, ILC Yearbook 1982, vol. II (Part Two), at 53 (para. 10). This observation became particularly evident in the (unsuccessful) drafting history of Article 36bis of the draft Articles. For a discussion see Catherine Brölmann, The Institutional Veil in Public International Law (Oxford: Hart Publishing 2007), 212-225. In commenting on the DARIO on
} 
accordingly be argued that States should first exhaust "local remedies" within the internal constitutional order - be they of a political, judicial, or quasi-judicial nature - to resolve the dispute with the international organization before turning to means of self-help such as countermeasures in international law. ${ }^{272}$ Indeed, the ASR and the DARIO stipulate strict conditions for the use of countermeasures, stating inter alia in Articles 52 (3) lit. b) and 52 (2) lit. a), respectively, that an injured party may not resort to countermeasures as long as a dispute settlement procedure aiming at the cessation of the wrongful act and the provision of reparation is pending. ${ }^{273}$ Considering that the admissibility of countermeasures between autonomous subjects of international law is sufficiently regulated by the ASR and the DARIO, the inclusion of Article 51 of the DARIO concerning special rules on countermeasures between an international organization and its member States is wholly unnecessary and possibly misleading.

In fact, retaining Article 51 in the DARIO on second reading may convey the impression that a member State could take countermeasures against an international organization in the internal legal order of the organization. In other words, Article 51 appears to suggest that a member State can react with a countermeasure, defined as non-compliance with an international obligation towards the organization, to the breach of an internal constitutional rule of the organization by an organ of that organization. ${ }^{274}$ This situation could be illustrated as follows: a UN Member State could decide to suspend compliance with an international agreement that it concluded as a State with the United Nations if the UN Security Council acts outside its competences under the UN Charter. As an alternative scenario, a UN Member State could decide to disobey an internal act of the organization, such as a Security Council resolution, due to the fact that this resolution violates international human rights obligations that are owed to the State as well. Considering that the relationship between an international organization and members is of an internal constitutional nature, the inevitable result of such a resort to international "countermeasures" would be the undermining of the autonomy of an international organization's internal legal order.

first reading States and international organizations noted that the "[m]ultiple layers of relationship between an international organization and its members States do not seem to be adequately taken into consideration.” See UN Doc. A/CN.4/637 (2011), at 36 (comments by the ILO), and UN Doc. A/CN.4/636 (2011), at 6 (comments by Austria).

${ }^{272}$ On the implementation of responsibility of international organizations Pierre Klein, La responsabilité des organisations internationales dans les ordres juridiques internes et en droit de gens (Bruxelles: Bruylant 1998), at 543, observing that nonjudicial means of dispute settlement are untypical in the implementation of responsibility of international organizations.

${ }^{273}$ For an interpretation of this limitation see Air Services Agreement (France v. United States), Arbitral Award of 9 Dec. 1978, 18 RIAA 416, referring inter alia to Article 33 of the UN Charter and to specific obligations under the 1946 Agreement. In this context, it is significant that the arbitral tribunal stated at para. 81 and 94 : "Under the rules of present-day international law, and unless the contrary results from special obligations arising under particular treaties, notably from mechanisms created within the framework of international organisations, each State establishes for itself its legal situation vis-à-vis other States. [...] If the proceedings form part of an institutional framework ensuring some degree of enforcement of obligations, the justification of counter-measures will undoubtedly disappear, but owing to the existence of that framework rather than solely on account of the existence of arbitral or judicial proceedings as such.”

${ }^{274}$ It is noteworthy that the ILC assumes in its Commentary to Article 27 of the draft Articles on the Law of Treaties between International Organizations and States that the organization may invoke a breach of its rules to justify a violation of its international obligations vis-à-vis a member State. However, the ILC reserves the validity of this statement with a reference to Article 73 of the draft Articles and the then on-going work of the ILC on State Responsibility (ILC Yearbook 1982, vol. II (Part Two), at 39 (para. 4)). 
Although countermeasures by members of international organizations have unsurprisingly not found any confirmation in practice, ${ }^{275}$ a limited number of scholars maintain that member States regularly disobey the acts of international organization and characterize this disobedience with reference to the law of international responsibility. ${ }^{276}$ Indeed, members sometimes disobey the internal acts of international organizations; however, such disobedience is rather the result of the constant tension between the will of individual member States and the collective volonté distincte of the international organization that characterizes the autonomous life of an international organization. ${ }^{277}$ Since virtually all international organizations share their competences with their member States, these States will interpret the acts of the organization conjointly with the international organization, for instance, when implementing a decision of an international organization in their respective national legal orders. ${ }^{278}$ When becoming members of an international organization, States retain a part of their right to auto-interpretation, which enables them to reconcile the obligations stemming from the act of the international organization with their other domestic or international obligations. ${ }^{279}$ If in this process of interpretation a member State is unable to reconcile its different obligations, it may claim that the international organization has overstepped its competences and acted illegally in the sense of ultra vires. As a result, the member State may decide not to comply with the act of the international organization's act so as to avoid a breach with its other obligations. Paraphrasing this lack of obedience as a countermeasure, however, transposes this violation into an external contractual breach whereas such a refusal to comply is of a purely internal nature.

Therefore, instead of characterizing this disobedience as countermeasure against the organization, it is suggested to use a term that expresses the internal institutional relationship between the organization and its member States, such as "institutional disobedience". ${ }^{280}$ Both acts of

\footnotetext{
${ }^{275}$ See ILC Report, Sixty-first Session, UN Doc. A/64/10 (2009) to Article 51.

${ }^{276}$ See, in particular, Antonios Tzanakopoulos, Disobeying the Security Council. Countermeasures Against Wrongful Sanctions (Oxford: OUP 2011).

${ }^{277}$ See Shabtai Rosenne, 'Is the Constitution of an International Organization an International Treaty', (1966) 12 Communicazioni e Studi 21-89, at 68.

${ }^{278}$ With regard to the harmonization of obligations arising from different treaty regimes see also the Conclusions of the ILC Study on Fragmentation of International Law, UN Doc. A/61/10 (2006), para. 251, in particular conclusion (26).

${ }^{279}$ The question is therefore not whether member States have given up their "right to auto-determination”, as a corollary of the right to auto-interpretation, but rather to which extent States have given up their right to auto-determination by becoming members of an international organization. As Monaco notes: “En d'autres termes, dès lors qu'un Etat accepte de devenir membre de l'Organisation, il n'a plus la faculté d'autodétermination, si ce n'est dans le respect des engagements pris. Le lien d'association qui rend applicable à cet Etat les normes particulières de l'ordre de l'Organisation ne peut être éliminé à la discrétion de l'Etat lui-même." Ricardo Monaco, 'Le caractère constitutionnel des actes institutifs d'organisations internationales’, in Mélanges offerts à Charles Rousseau: La Communanté internationale (Paris: Editions A. Pédone, 1975), 153-172, at 163. For a different view see Antonios Tzanakopoulos, Disobeying the Security Council. Countermeasures Against Wrongful Sanctions (Oxford: OUP 2011), 112-137, concluding that members generally still retain their right to autodetermination under international law even when becoming members of an international organization.

${ }^{280}$ The term "institutional disobedience" is adopted for present purposes to illustrate the situation in which a member State protests or resists the act of an international organization in the framework of the constitutional order of an international organization that prescribes the allocation of competences. Although certain parallels will be drawn, term "civil disobedience" is avoided due to its controversial meaning. It is acknowledged that other authors apply the concept of civil disobedience to international organizations. See, for instance, Antonios Tzanakopoulos, Disobeying the Security Council. Countermeasures Against Wrongful Sanctions (Oxford: OUP 2011), at 159, using the term "civil disobedience" to construe his argument of countermeasures against unlawful Security Council actions. However, the author does not seem to distinguish between the internal constitutional order of an international organization and international law and eventually equates such disobedience with countermeasures. (ibid. at 174ff.).
} 
disobedience and countermeasures can be characterized as illegal measures of last resort. Yet, the latter are generally seen as means of private law enforcement in the decentralized international system whereas the former will eventually come before a court in a centralized system that will decide whether the protested act is unlawful, and thus whether the act of disobedience is justified and thus lawful. ${ }^{281}$ Although most international organizations do not have appropriate judicial mechanisms to address such claims of legality and validity, to use domestic public law terminology, the constituent instruments of international organizations generally provide at least for some form of review in a political forum, often the main or plenary body of the organization. ${ }^{282}$ As a result of the disobedience by one or more member States, the act of the organization may be revoked, annulled or amended, if those States find sufficient support within the general membership. ${ }^{283}$ A successful example of such an amendment may be the UN's reaction to several domestic court decisions, including the ECJ's judgment in the Kadi case, concerning the inconsistency of UN Security Council sanctions regimes with fundamental standards applicable in the respective internal legal orders or customary international law. ${ }^{284}$ In this sense, the dilemma of an unavoidable breach may induce the member States of an international organization to change the contested act in question, and to avoid future situations of illegality. It could even be argued that the general rules on State responsibility, together with the prospect of accountability in other legal orders, may generate internal effects by inducing member States to establish or improve internal control mechanisms. ${ }^{285}$ By counteracting violations of

\footnotetext{
${ }^{281}$ See Antonios Tzanakopoulos, Disobeying the Security Council. Countermeasures Against Wrongful Sanctions (Oxford: OUP 2011), 160.

${ }^{282}$ See Ebere Osieke, ‘The Legal Validity of Ultra Vires Decisions of International Organizations’, (1983) 77 AJIL 239-256, at 243. As Lauterpacht observed, "[t]he extent to which acceptability determines legality is controlled by the legal system surrounding the conduct in question.” Elihu Lauterpacht, 'The Development of the Law of International Organization by the Decisions of International Tribunals', (1976-IV) 152 Recueil des Cours 377-478, at 393-94. In studying the practice of international organizations, the ILA observed in its 2004 Report: "The history of IO-s is replete with examples of political remedies available to Member States within the internal sphere of the IO such as withholding reappointment of high officials or challenging before a particular organ one of the decisions it has taken.” ILA Committee on the Accountability of International Organisations, Report of the Seventy-First Conference, Berlin (2004), 206.

${ }^{283}$ While these actions have been qualified as "juridical restitution" by Tzanakopulos, the use of this term may give the wrong impression that they are a reaction to a prior internationally wrongful act of the international organization towards its member States, which is indeed assumed by the author. See Antonios Tzanakopoulos, Disobeying the Security Council. Countermeasures Against Wrongful Sanctions (Oxford: OUP 2011), at 145.

${ }^{284}$ For a critical assessment of the gradual evolution of the UN counter-terrorism sanctions regimes see Thomas Biersteker and Sue Eckert, Addressing Challenges to Targeted Sanctions: An Update to the "Watson Report", UNO Academia/Graduate Institute for International and Development Studies/Watson Institute for International Studies (2009), available at http://www.watsoninstitute.org/project_detail.cfm?id=4 (last visited on 20 April 2011). Interestingly, the United Nations referred to the Kadi case in its comments on Article 16 of the DARIO on first reading: "In the Kadi case decided before the European Court of Justice, the Court held that its judicial review was not of the legality of the Security Council resolution under international law, but that of its implementing Regulation within the EU legal order. Its conclusion was premised on the assumption that States remain free to choose the particular model of implementation of Security Council resolutions in their domestic legal order, and that giving effect to Security Council resolutions must be in accordance with 'the procedures applicable in that respect in the domestic legal order of each member of the United Nations'." UN Doc. A/CN.4/637/Add.1, at 33 (para. 8).

${ }^{285}$ See Gaetano Arangio-Ruiz, 'International Law and Interindividual Law’, in Janne Nijman and André Nollkaemper (eds.), New Perspectives on the Divide between National and International Law (Oxford: OUP 2007) 15-52, at 43; and Bruno Simma and Dirk Pulkowski, 'Of Planets and the Universe: Self-contained Regimes in International Law', (2006) 17 EJIL 483-529, arguing at 501 that the unilateral enforcement of obligations undoubtedly constitutes an 'emergency operation' but that the prospect of countermeasures contributes to creating future expectations of effective enforcement in the international community generally and in self-contained regimes more specifically.
} 
the obligations by the organization, such control mechanisms contribute to the effective functioning of the organization.

If the international disobedience by one or several member States continues, or extends to elementary provisions in the legal order of the organization such as those concerning financial resources, the international organization may be threatened in its existence. ${ }^{286}$ The United States, for instance, withheld their contributions to the United Nations on several occasions, which commentators associated with a "constitutional crisis" ${ }^{287}$ If such measures lead to the diminution of the autonomy of an international organization and its eventual possible de facto or de jure termination, they could indeed be characterized as countermeasures and not as mere civil disobedience anymore. However, such countermeasures would not be directed against the international organization but against the other contracting parties to the constituent instruments. ${ }^{288}$ It is only if the organization fails to function effectively that States may resort to measures of self-help, not in their capacity as member States but as States, to address violations of the collective rights and obligations that are enshrined in the constituent instruments of an international organization. ${ }^{289}$

\section{Conclusion: No International Responsibility without Autonomy}

The law of international responsibility presupposes that international organizations have autonomy from their member States: Without a volonté distincte international organization cannot incur a

\footnotetext{
${ }^{286}$ Morgenstern therefore notes that as long acts of disobedience such as the withholding of assessed contributions remain isolated phenomena "they do not seriously call into question the view that the process is a necessary one at the present stage of development of international organizations. If there ceased to be acquiescence, on a wider scale, the problem might become one, not of methods of applying and modifying the law, but of survival of organizations.” Felice Morgenstern, 'Legality in International Organizations', (1976-1977) 48 BYIL 241-257, at 256 [emphasis added]. Institutional disobedience is thus balance by what Alvarez calls "institutional effectiveness"; see Jose Alvarez, 'Legal Remedies and the United Nations à la Carte Problem', (1990-1991) Michigan Journal of International Law 229-311, at 311.

${ }^{287}$ The phrase "constitutional crisis” is borrowed from Michael Reisman, 'The Constitutional Crisis in the United Nations', (1993) 87 AJIL 83-100, who uses it to describe the tensions resulting from the constitutional ambitions of the United Nations after the end of the Cold War. For a more specific discussion of the constitutional implications of a refusal to may membership contributions see Frederic L. Kirgis, 'Admission of 'Palestine' as a Member of a Specialized Agency and Withholding the Payment of Assessment in Response', (1990) 84 AJIL 218-230; Elisabeth Zoller, "The "Corporate Will” of the United Nations and the Rights of the Minority', (1987) 81 AJIL 610-634, as criticized by Jose Alvarez, 'Legal Remedies and the United Nations à la Carte Problem', (1990-1991) Michigan Journal of International Law 229-311. In its 2004 Report, the ILA observed: "Remedial actions belonging to the political/administrative sphere may also give rise to legal problems of a constitutional nature such as in cases of refusal to pay the assessed contribution under the regular budget of an IO, or temporary or permanent withdrawal from the IO.” ILA Committee on the Accountability of International Organisations, Report of the Seventy-First Conference, Berlin (2004), 206.

${ }^{288}$ In terms of implementation, this seems to be a rather hypothetical scenario. See on this hypothesis that member States of the EU or WTO "fall-back" to the general law of responsibility, see Bruno Simma and Dirk Pulkowski, 'Of Planets and the Universe: Self-contained Regimes in International Law', (2006) 17 EJIL 483-529. If member States are dissatisfied with the decisions of an international organization, they may consider the option of withdrawal from the organization; for a discussion see Joseph H.H. Weiler, 'Alternatives to Withdrawal from an international organization: The Case of the European Economic Community’, (1985) 20 Israel Law Review 282-298.

${ }^{289}$ In a similar vein, Antonios Tzanakopoulos, Disobeying the Security Council. Countermeasures Against Wrongful Sanctions (Oxford: OUP 2011), at 182, examining the UN Charter with regard to the concepts fo "integral obligations" and "interdependent obligations"; however, the author eventually concludes that member States can take countermeasures against the international organization itself. On the multilateral nature of disputes within international organizations see also Giorgio Malinverni, The Settlement of Disputes in International Organizations', in Mohammed Bedjaoui (ed.), International Law Achievements and Perspectives (Paris: UNESCO 1991), 544-587, at 546.
} 
responsabilité distincte. ${ }^{290}$ Nonetheless, in its work on the responsibility of international organizations, the International Law Commission has so far - albeit sometimes unintentionally - made propositions that undermine the autonomy of international organizations by avoiding a clear characterization of the legal nature of the so-called "rules of the organization". Instead of consistently recognizing that these rules are "internal law of the organization", the ILC suggests in respect to several important provisions of the DARIO that the rules of organization could be part of international law.

After considering the origins of the term "rules of the organization" in the ILC's early work on the law of treaties and the representation of States, this paper has argued that the DARIO on first reading fail to sufficiently distinguish between the internal constitutional law of the organization and the contractual law that has given rise to the organization, and that is generally referred to as lex specialis for the purposes of international responsibility. The constituent instruments of an international organization are only contracts at the moment of its creation - the fusion of the individual wills of the contracting parties into the corporate will of the organization by means of a collective conferral of competences - and its possible termination; during the life of an international organization they operate as constitutions that guarantee the autonomy of an international organization and that of its internal legal order. As long as the international organization is functioning effectively, the rules of the organization should therefore be understood as internal law, and not as lex specialis between States.

If applied to the relations between international organizations and their member States, as suggested by Article 63 of the DARIO, the use of the lex specialis-lex generalis principle is not only misleading, but may have negative implications for the law of international responsibility as a whole. It could, for instance, be taken to suggest that member States can internally - that is by virtue of internal rules of the organization - contract out of the general regime of international responsibility vis-à-vis third parties, and thus avoid compliance with other international obligations. Indeed, it has been argued by many commentators that the ECtHR in Behrami and Saramati case and the CFI in the Kadi case have not held their member States responsible for violations of their obligations under the respective treaty regimes by deferring to the UN Charter. In order to prevent such an undue limitation of the scope of application of the general rules of international responsibility, it has been proposed in this paper to replace the ambiguous term "rules of the organization" by "internal law of the organization” in the text of the DARIO or/and in the ILC Commentary. Such a replacement would not only clarify the relationship between the UN Charter and the constituent instruments of other international organizations, as founding documents of co-existing and autonomous legal persons, but would also allow the ILC to highlight the merits and limits of the oft-criticized analogy of the DARIO with the ASR.

\footnotetext{
${ }^{290}$ As Blokker notes: "Denying or restricting responsabilité distincte can in the end sacrifice the volonté distincte which is sought." Niels Blokker, 'International Organizations and Their Members. International Organizations Belong to All Members and to None' - Variations on a Theme', (2004) 1 IOLR 139-161, at 161. The same holds true the other way around: Denying or restricting the volonté distincte may sacrifice its responsibilité distincte, which the DARIO seek to establish if the conditions for the internationally wrongful act by an international organization are fulfilled.
} 
Against this background, it has been suggested that the DARIO, like the ASR, should make clear that the existence of an internationally wrongful act is governed by international law and does not depend on the characterization of that act under the internal law of the organization. Article 9 (2) of the DARIO on first reading thus wrongly suggests that a breach of the internal "rules of the organization" could result in the international responsibility of an international organization. Unlike States, however, international organizations are considered to have functional limitations so that the internal division of competences between an international organization and its member States may indeed be significant for the determination of the entity on which the obligation breached is incumbent. In this sense, the determination of the breach coincides with or even precedes the attribution of conduct, since the internal law of the organization will equally have a role to play in the decision whether a member State, or other entity or person, has acted as an organ under the normative control of the organization pursuant to Article 5 or as an agent under its factual control as implied by Article 6 of the DARIO. Since international organizations generally exercise their competences concurrently with their (member) States, the result of this concurrent attribution of conduct will most likely be a form of shared responsibility between multiple actors, which is possibly implemented in different legal orders.

Considering the content of this international responsibility, the DARIO, like the ASR, stipulate that international organizations have a duty to make reparation as the legal consequence of their wrongful conduct under Article 30 of the DARIO. They cannot rely on their internal law to justify non-compliance with their international secondary obligations as stated by Article 31 of the DARIO. Unlike States, however, international organizations do not have their own financial or other resources. Accordingly, Article 39 of the DARIO emphasizes that member States have an internal obligation towards the organization to provide it with the necessary means to make such reparation. By taking into account the dual nature of the constituent instruments, the ILC should underline that this obligation is based on a collective contractual undertaking by the parties to the constituent instruments of an international organization to ensure the effective functioning, or factual autonomy of the organization. If an international organization fails to function effectively due to internal institutional disobedience by its member States, the contracting parties to its constituent instruments may reappear behind the constitutional veil of the organization and resort to the general rules on international responsibility, including countermeasures, for law enforcement. Yet, contrary to what is currently implied in Article 51 of the DARIO, such countermeasures would not be directed against the organization itself, but against the other contracting parties to the constituent instruments. States may only take countermeasures against an international organization in their capacity as States, that is in their external relations with the organization on the basis of international obligations; however, it could certainly be argued that member States are obliged by international law to first exhaust the available "local remedies" provided in the internal legal order of the organization before impeding the effective functioning of the constitutional order that they have created. 
While the characterization of the rules of the organization as internal law of the organization would clarify the scope of application of the law of international responsibility, it does not come without drawbacks: the recognition that international organizations are autonomous legal orders would substantially limit the relevance of the DARIO and - more importantly - the ASR in holding international actors accountable, recalling the catchphrase of "fragmentation" of international law. ${ }^{291}$ It is therefore understandable that the ILC has circumvented the specific qualification of the legal nature of the rules of the organization with a general reservation to lex specialis in its work on the responsibility of States. However, paradoxically the recognition of the internal law of international organizations is necessary to give further meaning and purpose to the DARIO against the background of the work of the ILC as on the responsibility of States as unitary and autonomous actors in international law. A solution to this paradox may lie in the fact that independent or distinct responsibility does not exclude shared responsibility, for autonomy - other than international legal personality - is a matter of degree. Despite procedural limitations to implement this shared responsibility, the ILC's understanding of “objective” international responsibility does not depend on the invocation of this responsibility by the injured party. Consequently, members of international organizations have made an effort to reconcile their different obligations in order to avoid internal or international responsibility, which is most noticeable at the level of the UN sanctions regimes. Instead of over-emphasizing the increasing fragmentation of international law, it may then become more appropriate to resort to more neutral terms such as "specialization" 292 or "pluralization" 293 to capture the growing complexity of international relations, in which international organizations form specialized legal orders that interact and exist side by side with States.

\footnotetext{
${ }^{291}$ See also Bruno Simma and Dirk Pulkowski, 'Of Planets and the Universe: Self-contained Regimes in International Law', (2006) 17 EJIL 483-529, noting at 495 that "the claim of self-containment is intrinsically linked to a particular outlook on the international legal order", and the discussing the implications of giving priority to either the "planets" or the "universe" with regard to the law of State responsibility.

${ }^{292}$ While the term "specialization" may also be taken to allude to lex specialis, it should be more appropriately seen in connection with the "principle of speciality" that characterizes the partial legal orders of international organizations. In commenting on the DARIO on first reading international different international organizations have criticized the ILC for not having taken the principle of speciality sufficiently into consideration. See UN Doc. A/CN.4/637 (2011) at 11, 24, 39, 40, and Add. 1 (2011), at 1.

${ }^{293}$ As Lagrange succinctly notes : "Le développement des organisations internationales n’est pas en lui-même un principe organisateur, centralisateur ou unificateur de l'ordre international. Au contraire, il exprime le pluralisme.” Evelyne Lagrange, La représentation institutionnelle dans l'ordre international. Une contribution à la théorie de la personnalité morale des organisations internationales (The Hague: Kluwer 2002), at 46. See also Janne Nijman and André Nollkaemper, 'Beyond the Divide', in André Nollkaemper and Janne Nijman (eds.), New Perspectives on the Divide Between National and International Law (Oxford: OUP 2007) 341-360, suggesting at 359 the term "global legal pluralism” instead of the traditional term "legal pluralism", which is often used synonymously with dualism.
} 